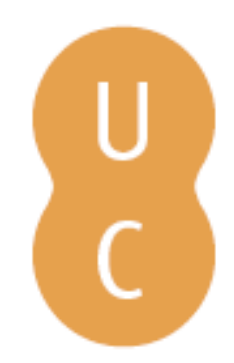

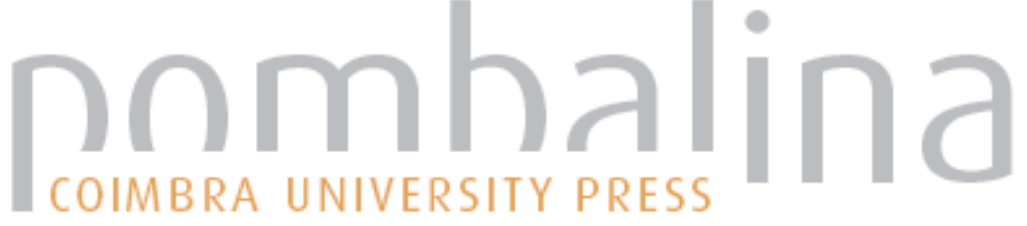

\section{O teatro grego em contexto de representação}
Autor(es):
Castiajo, Isabel
Publicado por: Imprensa da Universidade de Coimbra
URL persistente:
URI:http://hdl.handle.net/10316.2/5653
DOI:
DOI:http://dx.doi.org/10.14195/978-989-26-0271-4

Accessed : $\quad$ 26-Apr-2023 15:32:35

A navegação consulta e descarregamento dos títulos inseridos nas Bibliotecas Digitais UC Digitalis, UC Pombalina e UC Impactum, pressupõem a aceitação plena e sem reservas dos Termos e Condições de Uso destas Bibliotecas Digitais, disponíveis em https://digitalis.uc.pt/pt-pt/termos.

Conforme exposto nos referidos Termos e Condições de Uso, o descarregamento de títulos de acesso restrito requer uma licença válida de autorização devendo o utilizador aceder ao(s) documento(s) a partir de um endereço de IP da instituição detentora da supramencionada licença.

Ao utilizador é apenas permitido o descarregamento para uso pessoal, pelo que o emprego do(s) título(s) descarregado(s) para outro fim, designadamente comercial, carece de autorização do respetivo autor ou editor da obra.

Na medida em que todas as obras da UC Digitalis se encontram protegidas pelo Código do Direito de Autor e Direitos Conexos e demais legislação aplicável, toda a cópia, parcial ou total, deste documento, nos casos em que é legalmente admitida, deverá conter ou fazer-se acompanhar por este aviso.

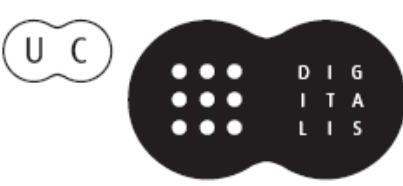




\title{
O Teatro Grego \\ EM CONTEXTO \\ DE REPRESENTAÇÃo
}

\author{
ISABEL \\ CASTIAJO
}


(Página deixada propositadamente em branco) 


\section{Isabel Castiajo}

O Teatro Grego
em Contexto de Representaçáo 


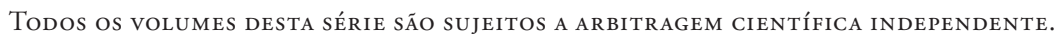

Título • O Teatro Grego em Contexto de Representaçấo

Autor • Isabel Castiajo

\section{Série Monografias}

Coordenador Científico do plano de ediçâo: Maria do Céu Filho

Comissáo Edtorial

José Ribeiro Ferreira

Francisco de Oliveira

Maria de Fátima Silva

Nair Castro Soares

Diretor Técnico: Delfim Leăo

Obra Realizada no Âmbito das actividades da UI\&D

Centro de Estudos Clássicos e Humanísticos

\section{Ediçẫo}

Imprensa da Universidade de Coimbra

URL: http://www.uc.pt/imprensa_uc

E-mail: imprensauc@ci.uc.pt

Vendas online:

http://www.livrariadaimprensa.com

CoordenaÇão EDITORIAL

Imprensa da Universidade de Coimbra

CoNCePÇÃo GRÁFICA

Rodolfo Lopes

INFOGRAFIA

Carlos Costa
Impressáo e Acabamento

www.artipol.net

ISBN

978-989-26-0157-1

ISBN Digital

978-989-26-0271-4

DOI

http://dx.doi.org/10.14195/978-989-26-0271-4

Depósito Legal

$350005 / 12$

1a EDIÇÃO: IUC • 2012

(C) JULHO 2012.

IMPRENSA DA UNIVERSIDADE DE CoIMBRA

Classica Digitalia Vniversitatis Conimbrigensis (http://classicadigitalia.uc.pt)

Centro de Estudos Clássicos e Humanísticos da Universidade de Coimbra

Reservados todos os direitos. Nos termos legais fica expressamente proibida a reproduçáo total ou parcial por qualquer meio, em papel ou em ediçấo electrónica, sem autorização expressa dos titulares dos direitos. É desde já excepcionada a utilizaçâo em circuitos académicos fechados para apoio a leccionação ou extensão cultural por via de e-learning. 


\section{ÍNDICE}

$\begin{array}{ll}\text { INTRODUÇÃO } & 7\end{array}$

1 - Festivais Dionisíacos 11

1.1 - Dionísias Rurais 13

$\begin{array}{ll}1.2 \text { - LENEIAS } & 15\end{array}$

1.3 - Antestérias $\quad 18$

1.4 - Grandes Dionísias 20

2 - Edifício Teatral 31

3 - Máscaras

4 - Vestuário

4.1 - Calçado 74

5- AtOREs

5.1 - NÚMERo $\quad 79$

5.2 - Designação

$5.3-\mathrm{Voz} \quad 84$

5.4 - Gestos

$\begin{array}{ll}5.5-\text { DANÇA } & 92\end{array}$

5.6- Ensaios 94

5.7 - Concursos 95

5.8 - Evolução 98

$\begin{array}{ll}6 \text { - Coro } & 101\end{array}$

6.1 - Participação 103

$\begin{array}{ll}6.2 \text { - Evolução } & 105\end{array}$

$\begin{array}{ll}6.3 \text { - ENSAIOS } & 108\end{array}$

$\begin{array}{ll}6.4-\text { FunÇÕES } & 109\end{array}$

$6.5-\mathrm{Voz} \quad 113$

6.6- Movimento 118

$\begin{array}{ll}\text { 6.6.1 - DANÇA } & 122\end{array}$

$\begin{array}{ll}7 \text { - PÚBlico } & 125\end{array}$

$\begin{array}{lr}\text { Conclusão } & 137\end{array}$

$\begin{array}{ll}\text { BiBLIOGRAFIA } & 141\end{array}$ 
(Página deixada propositadamente em branco) 


\section{INTRODUÇÃO}

Este trabalho resulta, antes de mais, da simbiose perfeita entre dois mundos que são meus - o admirável mundo da Civilização e Cultura Gregas do século V a.C. e o fantástico mundo da representação -, porque os sinto como partes integrantes da pessoa que hoje sou, já que me acompanharam desde tenra idade, concretamente, naquela em que se definem os principais traços da personalidade, a adolescência.

E se até aqui esta vivência foi sendo realizada de forma bipartida, na medida em que cada um dos mundos tinha o seu espaço e contexto específicos - o da Faculdade e o dos vários grupos de teatro por onde fui passando desde os 16 anos de idade - hoje e com este trabalho esses dois mundos fundiram-se através da conjugação inevitável, que foi sendo operada à medida que o trabalho se ia realizando, dos saberes e sensibilidades intrínsecos a cada um deles; e creio que, por isso, ambos foram mais enriquecidos como mais enriquecida se tornou a minha vivência.

Assim, como se pretendia, em primeira instância, apresentar com este trabalho uma visão global das várias componentes que constituíam o teatro grego, bem como do contexto social, político e religioso em que este acontecimento estava envolvido, a opção foi começar por caracterizar o conjunto dos quatro festivais dedicados a Diónisos, partindo, exatamente, da sua essência religiosa e da comunhấo que durante anos subsistiu entre essa essência e o teatro em si. Impôs-se, por isso, a descrição das partes constituintes de cada festival bem como das estruturas políticas que viabilizaram a realização destes eventos, com o objetivo de ilustrar as várias dimensôes subjacentes a este acontecimento, bem como o grau de importância que o teatro foi assumindo na configuração do espaço grego, desde a Época Clássica até à Helenística, com especial incidência no período em que se operou o verdadeiro apogeu do teatro ocidental, o século $\mathrm{V}$ a.C. Por esta razáo e sobretudo por se tratar de uma questáo muito controversa que exigiria outra tese somente para abordar o assunto, náo foi dado especial destaque às origens do teatro em si, embora a espaços, e quando 
tal opção se afigurava como pertinente, tenham sido aflorados alguns aspetos decorrentes dessa problemática. Também não foi objeto de estudo aprofundado a vida, obra e estilo de cada um dos grandes tragediógrafos e comediógrafos gregos que a história consagrou, dado que também para a abordagem desse assunto seria necessário um estudo autónomo que lhe conferisse o devido destaque. De qualquer forma, sempre que se justifique e como forma de ilustrar determinadas situaçôes, quer os poetas gregos desta altura quer as suas obras foram citados.

Interessava, pois, o enfoque na Época Clássica e na tentativa de reconstruçáo deste acontecimento à luz desse período, com todas as implicaçóes que a mesma exigia. Era, por isso, também inevitável o aprofundamento de questôes relacionadas com o espaço onde decorriam estes eventos e, consequentemente, com a análise da evolução do edifício teatral, desde a Ágora, passando pela encosta sul da Acrópole até à construção do primeiro edifício em pedra, no século IV a.C.

Seguiu-se a abordagem aos aspetos acessórios que ainda hoje ocupam um lugar de relevo em qualquer produçáo teatral, como sendo o vestuário usado pelas personagens e, como não podia deixar de ser, o recurso à máscara que, por ser um elemento tão característico do teatro grego e por ter tão elevadas implicaçóes funcionais, relacionadas quer com as características do edifício teatral quer com a gestáo do número e tipo de atores disponíveis para a consecução dos espetáculos, não poderia nunca dispensar uma análise mais detida.

Aos atores, elementos fundamentais e indissociáveis do teatro, foi dada especial atenção, sobretudo no que concerne à polivalência generalizada de que estes agentes estavam dotados e à evoluçáo por eles protagonizada, relativa ao estatuto e ao caráter insubstituível que foram alcançando ao longo dos tempos e que acabaram por conduzir a uma secundarização da figura do coro, cuja evolução é também analisada. Veremos, pois, que de elemento fulcral nos primórdios do teatro, nomeadamente no que concerne aos ditirambos, o coro passou a ocupar, a partir de finais do século V a.C. e sobretudo na Época Helenística, um papel secundário nas composiçôes teatrais, já que neste período as suas intervençóes passaram a limitar-se ao cântico de embolima, nos interlúdios. De qualquer forma, constataremos ainda assim como é inegável a importância do papel do coro ao longo dos tempos, nomeadamente pelas múltiplas funçóes que 
sempre foi desempenhando no seio da ação dramática e pela versatilidade e polivalência destes elementos que, à semelhança dos atores, também cantavam e dançavam.

Por último, porque o objetivo de qualquer composição dramática é a sua representação perante o público e o teatro não vive sem audiência, procuraremos caracterizar a composição, natureza e comportamento dos espectadores que frequentavam estes eventos, bem como as condiçóes de acesso aos recintos do espetáculo.

Com esta estrutura, organização e enfoque em determinados aspetos, pretende-se, como objetivo último, o reconhecimento do teatro grego como um acontecimento multifacetado quer em termos de conceção, na medida em que apresentava diversas vertentes - religiosa, política, social, cultural -, quer em termos de articulação com outros domínios como a música, a dança, a poesia, de forma a que seja possível operar, na imaginação do leitor, uma reconstrução o mais aproximada possível daquilo que era o teatro com todas as implicaçóes subjacentes, sobretudo na Época Clássica, o período do seu apogeu.

Para finalizar, gostaria de deixar uma palavra de agradecimento aos meus pais, que sempre me conferiram total liberdade na escolha do meu caminho, ao Carlos que sempre me apoiou na consecução deste trabalho, às minhas irmãs e amigos que me foram prestando auxílio nas mais variadas questóes, à figura que carinhosamente sempre apelidei de Diónisos, e que na sua breve passagem terrena foi a que conheci que mais tenha encarnado o ideal dionisíaco e cuja inspiração ainda hoje emana do Olimpo, e sobretudo ao meu caro Magister, o Doutor Delfim Leão, a quem devo o crescimento e o enriquecimento que sinto que se operou em mim durante os dois anos em que me empenhei neste trabalho, que me conduziu de forma magistral em todo este processo e que simboliza metonimicamente a filosofia e o modus operandi do Instituto de Estudos Clássicos da Faculdade de Letras da Universidade de Coimbra. 
(Página deixada propositadamente em branco) 
1 - Festivais Dionisíacos 
(Página deixada propositadamente em branco) 
$\mathrm{Na}$ Ática, o período que compreendia toda a estação do inverno e o início da primavera era preenchido por Festivais Dionisíacos.

Em dezembro, no chamado mês de Poséidon, ocorriam as Dionísias Rurais; em meados do mês seguinte, durante o Gamélion, desenrolavam-se as Leneias; em fevereiro, entre os dias 11 e 13 do mês Antestérion, celebravam-se as Antestérias e, precisamente um mês depois, quando estavam já reunidas as condições propícias à navegação, tinham lugar as Grandes Dionísias. Nos finais do período clássico, em todos estes festivais decorriam concursos dramáticos.

\section{1 - Dionísias Rurais}

As festividades designadas por ta kat' agrous Dionysia eram um dos grandes acontecimentos do ano nos demos da Ática ${ }^{1}$. Eram celebradas em vários locais ${ }^{2}$ e apresentavam graus diferenciados de elaboração.

Ao que tudo indica, estes festivais terão começado por ser um cortejo fálico em direçáo a um centro de culto, a que se seguiria um sacrifício. ${ }^{3}$ As fontes antigas atestam o uso do falo e o entoar de cânticos obscenos no cortejo das Dionísias Rurais. ${ }^{4}$

Segundo Csapo \& Slater (2001: 104) e na sequência da comparação de material vário, é possível verificar-se uma relação estreita entre cortejos fálicos, libertinagem ritual, obscenidade e o uso de máscaras no culto grego, particularmente no dionisíaco. De qualquer forma e ainda no entender dos

${ }^{1} \mathrm{Na}$ opinião de Rehm (1992: 15-6), a maior parte dos testemunhos que atestam as Dionísias Rurais são do século IV a.C., facto que suporta a ideia de que, inicialmente, a tragédia teria sido importada das zonas rurais para a urbana e que, depois do seu florescimento nesta última, teria regressado às zonas rurais num estado de maior desenvolvimento.

${ }^{2}$ Segundo Csapo \& Slater (2001: 121), apenas em relaçâo a treze demos, de que são exemplo o Pireu, Acarnas, Elêusis, Salamina e Cólito, há alguma certeza quanto à existência de performances teatrais.

${ }^{3}$ Pickard-Cambridge (1953: 40), refere que não se sabe quando terá começado a ligaçấo do festival com Diónisos, mas que o rito era provavelmente mais primitivo do que o culto do deus na Ática e talvez não tivesse diretamente nada a ver com o vinho, ainda que não haja dúvidas de que este era largamente ingerido durante o festival. De qualquer forma, não se sabe em que altura é que as performances dramáticas começaram a estar associadas ao evento.

${ }^{4}$ Plutarco, Sobre a ânsia de riquezas, 527d; Aristófanes, Acarnenses, 241-279; Ateneu, Deipnosofistas, 14.621d-622d. 
autores, qualquer que fosse a prática original das Dionísias Rurais, que certamente diferia de demo para demo, o cortejo dos antigos festivais parece ter implicado o uso de máscaras pelos participantes.

O festival tinha, por conseguinte, dois momentos altos - o $k_{o m o s}$ - o cortejo onde era exibido e ostentado um falo, cujo objetivo era o de promover a fertilidade - e o askoliasmos ${ }^{6}$ - um concurso que consistia na tentativa de saltar ou permanecer sobre um odre cheio de vinho e untado.

Depois do komos e dos sacrifícios que a este se seguiam, tinham lugar a tragédia e a comédia ${ }^{7}$, às quais foram acrescentados os ditirambos nos finais do século IV a.C. ${ }^{8}$ e, pelo menos nos finais do século II a.C., aparentemente, as festividades duravam quatro dias (cf. SEG 15.104.25f.).

Para celebrar as vitórias alcançadas, durante o século IV a.C., vários coregos erigiram monumentos comemorativos. Através deles é possível verificar que a sincoregia, ou seja, a partilha da responsabilidade dos concursos por dois coregos em simultâneo, era uma prática comum neste tipo de festivais. Prova disso mesmo é visível em I.G.2.3090, onde consta a inscrição que figuraria num monumento comemorativo da vitória, por duas vezes, de dois sincoregos nas Dionísias de Elêusis, uma em 406-405 a.C., com as Rãs de Aristófanes, e a outra em 402-401 a.C., com o Édipo em Colono de Sófocles.

Apenas em Elêusis e possivelmente em Acarnas foi apresentado o rol completo de composiçôes dramáticas (ditirambo, tragédia e comédia) ${ }^{9}$; no entanto, ao que parece, o festival

${ }^{5}$ E.g. Aristófanes, Acarnenses, 241-279.

${ }^{6} \mathrm{O}$ concurso é descrito por Pólux (9.121) sem a referência a nenhum festival em particular. Segundo Pickard- Cambridge (1953: 40), era provavelmente uma prática usual em muitos festivais.

${ }^{7}$ Cf. Lei de Evégoros (ap. Demóstenes, Contra Mídias, 10).

${ }^{8}$ No Pseudo-Plutarco (Vida dos Dez Oradores, 842a), o autor lista vários fragmentos de legislação, introduzida por Licurgo, onde se refere que este instituiu que no Pireu, no mês de Poséidon, fossem a concurso náo menos do que três coros ditirâmbicos.

${ }^{9}$ Em vários outros demos a configuração dos concursos dramáticos era diferente. Em Tóricos, por exemplo, somente a tragédia e a comédia eram representadas. Já em Salamina, começaram por ser apresentados ditirambos e, mais tarde, a tragédia. Cf. Csapo \& Slater (1994: 121). Existem ainda testemunhos, nomeadamente num decreto do século V a.C. (COAD 126), que atestam a representação de tragédias, em Icárion. Cf. Wiles (1997: 23). 
do Pireu destacava-se como sendo mais importante do que qualquer outro.

No entender de Platão (Laques, 182d-183b) ${ }^{10}$, os festivais das Dionísias Rurais não passavam de um entretenimento de terceira categoria; no entanto, fontes literárias e epigráficas deixam bem evidente que os participantes nos concursos dramáticos eram, muitas vezes, de primeira qualidade. ${ }^{11}$ De qualquer forma, não se sabe se os poetas produziam peças propositadamente para este evento ou se os espetáculos a concurso tinham já sido apresentados nas Grandes Dionísias.

\section{2 - LENEIAS}

A localização dos festivais das Leneias é um assunto que continua a gerar controvérsia. Alguns estudiosos modernos, no seguimento de uma tradição que remonta já à Antiguidade, defendem que estes festivais se celebravam no mesmo templo (en Limnais) onde decorriam as Antestérias ${ }^{12}$, mas esta visão deve-se muito ao facto de desde a Antiguidade se confundirem estes dois eventos, pelo que parece mais razoável a opinião de Csapo \& Slater (1994: 123), quando afirmam que seria improvável que as Leneias fossem celebradas num templo que, como é evidente no discurso Contra Neera de Pseudo-Demóstenes (76), só abria um único dia por ano, no final da tarde do dia em que se festejava o ritual das Choes ('libaçóes') das Antestérias.

De qualquer forma, escoliastas e lexicógrafos divergem na localização do festival. Os primeiros, tendo como referência o escólio a Aristófanes (Acarnenses, 202, 504) e as declaraçóes de Estéfano de Bizâncio (Sobre Apolodoro, p. 274, vv. 8-10), que reclama a autoridade de Apolodoro, sustentam que os festejos decorreriam en agrois ('nos campos'), um local fora dos muros da cidade; os segundos defendem que o lugar da celebração seria o mercado, na cidade, a noroeste da Acrópole.

Hesíquio (s.v. Epi Lenaio agon) refere que o festival ocorria num local en astei ('na cidade', em Atenas) que tinha uma

${ }^{10}$ Desta opinião partilham também outros autores, como Demóstenes (Sobre a coroa, 180).

11 Segundo Eliano (História Vária, 2.13), Sócrates acompanhava as representaçôes de Eurípides. Quando este competiu no Pireu, o filósofo também teria estado presente.

12 Pickard-Cambridge (1953: 37) defende que esta visão se deve à passagem corrupta de Hesíquio (s.v. Limna). 
larga circunferência e dentro dela o hieron - o templo onde se desenrolavam os concursos dramáticos atenienses, antes e algum tempo depois da construção do teatro de Diónisos. É aqui que se acredita que as performances das Leneias se terão realizado, a partir de cerca de 440 a.C., altura em que o Estado estabeleceu um concurso formal de coregos e poetas. Fócio (s.v. $i k r i a)$ também refere a existência de ikria (os assentos de onde os espectadores assistiam aos concursos dionisíacos, antes de o teatro ser construído) e da Ágora - o mercado. Esta descrição parece ser corroborada pela existência de um lugar, na Ágora, denominado orchestra ${ }^{13}$.

$\mathrm{O}$ festival incluía um cortejo (pompe) conduzido pelo arconte basileus, o responsável pela maior parte dos deveres religiosos da monarquia proto-histórica, e pelo epimeletes. $\mathrm{O}$ cortejo parecia envolver rituais abusivos, mas, uma vez mais, é provável que esta constatação seja uma consequência da confusão recorrente entre as Leneias e as Antestérias ${ }^{14}$. Algumas inscrições revelam que haveria um sacrifício, mas não fornecem detalhes sobre a natureza desse ritual. Também não é certa a existência do komos.

Apesar de as inscriçóes atestarem a presença de concursos trágicos e cómicos desde meados do século V a.C. (c. 430 a.C., para a tragédia, e c. 440 a.C., para a comédia), acredita-se que as performances cómicas tinham, neste festival, um papel de maior relevo do que as tragédias. Assim, os grandes poetas trágicos raramente participavam nas Leneias, ao passo que era usual os poetas cómicos concorrerem indistintamente a qualquer festival. Aristófanes, por exemplo, foi um dos poetas cómicos que em 405 a.C., durante o arcontado de Cálias, participou nesses concursos dramáticos com Râs.

As didascálias revelam que, em finais do século V a.C., mais concretamente em 418, competiam apenas dois poetas trágicos, com duas tragédias cada um, sendo que não apresentavam qualquer drama satírico ${ }^{15}$. No entanto, no século IV, em 363 a.C., aparecem representados, também nas mesmas didascálias,

13 Vide Fócio, s.v. orchestra.

${ }^{14}$ Rehm (1992: 18) acredita que o cortejo não envolveria elementos fálicos.

${ }^{15}$ Cf. I.G. 2.2319 col. ii (Didaskaliai das tragédias representadas nas Leneias, entre 420-417 a.C.). 
três poetas trágicos. Torna-se assim impossível determinar qual das situações evidencia a norma.

Relativamente à comédia, há também dúvidas quanto ao número de representaçôes deste género nesse festival. Assim, se tivermos em conta as hypotheseis ('argumentos') das peças de Aristófanes, verifica-se que, em 405 a.C., quando o poeta se classificou em primeiro lugar, com $R a \tilde{s}$, estavam a concurso dois outros comediógrafos - Frínico com as Musas, que obteve o segundo lugar, e Platáo Cómico, que alcançou o terceiro lugar com a peça Cleofonte. No entanto, as didascálias revelam que em 284 a.C. foram produzidas cinco comédias ${ }^{16}$, daí que se acredite de forma generalizada que regularmente eram representadas cinco comédias nas Leneias, exceto durante a guerra do Peloponeso $(431 \text { - } 404 \text { a.C. })^{17}$.

No que diz respeito aos ditirambos, não são conhecidas quaisquer performances deste género no período clássico, mas a sua presença é atestada no século III a.C., através de uma inscrição relativa à vitória de um ditirambo ${ }^{18}$.

O festival era um acontecimento puramente ático, uma espécie de evento doméstico, inacessível aos estrangeiros e frequentado apenas por cidadáos ${ }^{19}$ e metecos, os quais podiam, inclusivamente, desempenhar as funçóes de coreutas ou coregos, o que, no entender de Rehm (1992: 21), era bem um espelho da importância do crescimento económico deste último grupo.

Quanto ao terminus dos concursos dramáticos, sabe-se que estes se desenrolaram mesmo depois da abolição da coregia; o facto de a lista das vitórias dos atores trágicos continuar até ao final do século III a. C., apesar de a última data fixada para a vitória dos poetas trágicos ser 320 a.C., demonstra que certamente o concurso de poetas prosseguiu também até esta altura. Já quanto à comédia, a lista da vitória dos poetas cómicos prolonga-se para além do ano 150 a.C.

${ }^{16}$ Cf. I.G. 2.2319 col. i (Didaskaliai das comédias representadas nas Leneias entre 285-4 a.C.).

${ }^{17}$ Cf. Rehm (1992: 18).

${ }^{18}$ Cf. Csapo \& Slater (1994: 124).

${ }^{19}$ Cf. Aristófanes, Acarnenses, 504, onde se descreve o festival como sendo um acontecimento próprio das Leneias, no qual não participariam estrangeiros. 


\section{3 - ANTESTÉrias}

As Antestérias, cujo nome, segundo Filóstrato (Heróico, 12.2), se devia ao facto de os rapazes e as raparigas que atingiam a adolescência usarem coroas de flores, são consideradas o festival de Diónisos mais antigo de Atenas, porquanto é provável que a festividade date de um período anterior à migração das tribos iónicas da Grécia para a Ásia Menor. Desenrolava-se entre os dias 11 e 13 do mês de Antestérion, sendo que cada um dos três dias era ocupado com um evento específico, embora todos eles fossem precedidos de uma cerimónia religiosa na tarde do dia anterior. O primeiro dia era conhecido como Pithoigia, o segundo era designado por Choes e o terceiro e último por Chytroi.

No primeiro dia do festival, Pithoigia, ou seja, na festa da abertura dos tonéis, as pessoas deslocavam-se para junto do Templo de Diónisos en Limnais, abriam os pithoi - as vasilhas que continham o vinho da colheita do último outono - e bebiam-no depois de prestarem as devidas libaçóes a Diónisos.

O segundo dia, Choes, o festival dos 'vasos de libaçôes', celebrava-se bebendo por toda a cidade através de recipientes com uma forma muito peculiar, apropriada à cerimónia. Desenrolava-se também um concurso de bebida, anunciado pelo som de um trompete, e solenemente conduzido pelo arconte até ao Thesmotheteion, onde todos bebiam em silêncio ${ }^{20}$. O prémio atribuído ao vencedor era um odre de vinho.

Ao mesmo tempo decorriam outros concursos de bebidas não oficiais e, no final do dia, os participantes colocavam as coroas ganhas à volta dos choes, que neste caso eram o prémio que distinguia o vencedor, levavam-nas à sacerdotisa do templo en Limnais e faziam libaçóes com o resto do vinho. Como já foi referido anteriormente, este era o único dia em que o templo tinha as portas abertas e era frequentado pelos participantes no festival até à noite.

O terceiro dia do festival, Chytroi, a festa das marmitas, iniciava-se na noite dos Choes, altura em que decorriam no templo as cerimónias secretas, conduzidas pelas catorze gerairai ('veneráveis' sacerdotisas de Diónisos) e preparatórias do casamento sagrado da Basilinna, a mulher do arconte-rei ou Basileus, com Diónisos ${ }^{21}$. Com esta união, que ocorria na

${ }^{20}$ Segundo a tradição, este ritual estará relacionado com a chegada de Orestes a Atenas, antes de ter sido purificado.

${ }^{21}$ Cf. Pseudo-Demóstenes, Contra Neera, 73-78. 
residência oficial do arconte-rei, pretendia-se simbolizar a simbiose do deus da fertilidade com a comunidade, representada pela mulher do chefe religioso.

O resto do dia era dedicado ao culto dos mortos, cujos fantasmas se acreditava que regressavam nesse dia e eram, por isso, tomadas medidas catárticas, como sendo o mascar de folhas de um arbusto designado de espinheiro-cerval ${ }^{22}$. No final do dia havia um choro geral ritualizado.

Sáo escassas as provas da existência de drama nas Antestérias. O único ponto de apoio é talvez o relato atribuído a Plutarco (Vida dos Dez Oradores, 841), que se refere aos agones chytrinoi, os concursos no dia dos Chytroi, que foram revitalizados por Licurgo, no terceiro quartel do século IV a.C., após um período de abstenção, e que estabeleciam que o vencedor passava a ter um lugar assegurado nas competiçóes das Grandes Dionísias. Esta é também a perspetiva assumida por Pickard-Cambridge (1953: 15) que defende que o festival ocorria numa altura conveniente para a escolha dos atores que participariam nas Grandes Dionísias, umas semanas mais tarde.

Para Csapo \& Slater (1994: 124) é, no entanto, pouco provável que as competiçóes dramáticas ocorressem antes do século IV a.C., tivessem depois desaparecido e fossem, mais tarde, reabilitadas por Licurgo. Assim, na opinião destes autores, as competiçôes dramáticas serão provavelmente uma inovação do estadista Licurgo (c. 330 a.C.) ou de um período posterior a este.

De qualquer forma, é comummente aceite que estes agones chytrinoi não constassem inicialmente das Antestérias, já que este último festival é mais antigo do que as Grandes Dionísias. Além disso, Pickard-Cambridge (1953: 15-16) - tendo em conta um relato escrito por Filóstrato (Vida de Apolónio, 4. 21) que se referia ao facto de Apolónio, no século I da nossa era, se ter sentido chocado nas Antestérias quando, em vez de ouvir cantar e recitar excertos de tragédias e comédias, como esperava, assistiu a danças lascivas - considera que, provavelmente, terão ocorrido grandes alteraçóes neste festival, sendo plausível que as danças atrás mencionadas tenham substituído os agones chytrinoi.

${ }^{22}$ É interessante verificar que o nome científico do arbusto é Rhamnus cathartica. 


\section{4 - Grandes Dionísias}

As Grandes Dionísias (ta Dionysia) foram um dos festivais urbanos impulsionados por Pisístrato, numa altura em que as sociedades gregas passaram de um sistema aristocrático predominantemente rural para uma fixação tendencialmente urbana. Assim, como forma de desenvolverem as bases urbanas, os tiranos consideraram conveniente dar brilho a muitos festivais rurais tradicionais, que se encontravam sob o controlo de aristocratas locais - as Dionísias Rurais - através da deslocação de importantes objetos de culto para centros urbanos e da instituição de grandes festivais citadinos ${ }^{23}$.

Estes festivais foram estabelecidos em honra de Diónisos Eleuthereus, cuja imagem terá sido trazida de Eleutherai para Atenas por um desconhecido, Pégaso, que seria provavelmente um sacerdote do culto do deus ${ }^{24}$. Segundo consta, a imagem não teria sido bem recebida, pelo que os Atenienses foram assolados por uma doença, da qual só se libertariam através do fabrico de phalloi em honra do deus; daí a relação sobejamente conhecida entre estes elementos característicos do festival e Diónisos.

$\mathrm{O}$ responsável pelas celebraçóes era o arconte-epónimo ${ }^{25}$ que tinha a seu cargo os custos da pompe e dos concursos dramáticos e ditirâmbicos. Para o auxiliar contava com a assistência de dois paredroi e dez epimeletai.

Uma das primeiras funçóes do arconte-epónimo era a escolha dos coregos trágicos ${ }^{26}$, elementos fundamentais para

${ }^{23}$ Cf. Csapo \& Slater (1994: 103). Da mesma opinião partilha Zimmermann (1991: 8), que defende que os motivos que estão por detrás desta atitude de Pisístrato foram, sobretudo, de índole política, já que, instituindo estes magníficos cinco dias de festival, os tiranos fizeram de Atenas o centro religioso da Ática e diminuíram o prestígio de cultos rurais vigentes em demos sobre o controle de aristocratas rivais; e, assim, provavelmente consagraram o festival a Diónisos para granjear popularidade.

${ }^{24}$ Cf. escólio a Aristófanes, Acarnenses, $243 \mathrm{a}$.

25 Segundo Csapo \& Slater (1994: 105), o facto de a responsabilidade da organização do festival recair sobre o arconte-epónimo, que era o principal oficial político do estado ateniense e não sobre o arconte-rei, que assumia a maior parte das funçóes religiosas da antiga monarquia ateniense, pode ser entendido como um sinal da reorganização política de Pisístrato.

${ }^{26}$ Segundo Wilson (1997: 96-7), de todos os tipos de coregia, o mais importante era o da tragédia, cuja nomeação dos três coregos era o segundo dever do arconte-epónimo, depois de ter assumido funçóes. Quanto aos coregos dos vinte coros ditirâmbicos, esses eram oficialmente identificados com a sua tribo, o mesmo se passando, relativamente à comédia, pelo 
o sucesso dos poetas em competição. Esta nomeação, como é óbvio, recaía sobre os cidadãos mais ricos ${ }^{27}$, porque, se ao Estado cabia a responsabilidade pelo pagamento dos atores, pelos honorários do poeta e pelo prémio atribuído ao vencedor, era papel do corego assumir os gastos decorrentes do ensaio dos coros, do seu vestuário e da sua alimentação, pelo que os coregos suportavam, então, os gastos inerentes aos figurinos, aos salários dos cantores, do chorodidaskalos e provavelmente dos flautistas. Parece também provável que oferecessem um jantar aos elementos do coro depois do festival, e sabe-se que era comum custearem as despesas inerentes à construçáo do monumento corégico, que mandavam erigir, como forma de comemorar e perpetuar a vitória granjeada ${ }^{28}$.

O eleito podia, no entanto, recusar a sua seleção, advogando a existência de outrem com maiores recursos ou alegando anteriores custos com outros eventos; daí que, por vezes, fosse difícil conseguir-se o número necessário de coregos. Talvez tenha sido por isso que, no ano de 406-405 a.C., o sistema da coregia tivesse sido substituído pelo da sincoregia, ou seja, um sistema que repartia a responsabilidade e os encargos financeiros de cada representação por dois cidadáos ${ }^{29}$.

Durante o regime de Demétrio de Fáleron, em Atenas, (317-307 a.C.), a coregia foi abolida e a organização do festival passou a ser atribuída a um agonothetes, eleito anualmente e provido de um fundo monetário para o desempenho do seu cargo. No entanto, quer o arconte-epónimo quer os epimeletas continuaram a executar as suas obrigaçóes.

Desconhece-se de que forma cada um dos coregos escolhia o seu poeta, mas não há dúvida de que todos eles competiam pelo melhor. Depois da atribuição do poeta e da contratação do flautista, o corego tinha que selecionar de entre a sua tribo

menos a partir do século IV a.C., altura em que parece provável que os coregos tivessem passado a ser nomeados pelas várias tribos, embora se desconheça até que ponto é que realmente as representariam.

27 De qualquer forma, esta situação não impedia que um cidadão comum se pudesse voluntariar para assegurar as despesas de um coro trágico ou cómico.

28 Wilson (1997: 91) defende que, tanto quanto se sabe, um corego trágico vitorioso era galardoado com uma coroa de hera, ao contrário do seu homólogo, no que diz respeito aos ditirambos, que recebia uma trípode a expensas da pólis. Cf. I.G. $\mathrm{II}^{2}$. 1635a A. 33-4.

${ }^{29}$ Cf. escólio a Aristófanes, Rãs, 406a. 
os elementos que constituiriam o coro ${ }^{30}$. Em meados do século IV a.C., se não antes, havia, provavelmente, uma classe de cantores profissionais a partir da qual o corego fazia a sua escolha. Sabe-se que os membros dos coros ditirâmbicos tinham que ser cidadãos de nascimento e que, aparentemente, os membros do coro de homens ficavam dispensados do serviço militar.

O coro era ensaiado por um chorodidaskalos, também ele obrigatoriamente cidadão e nomeado pelo corego, e recebia não só treino musical como também treino físico. Sabe-se, no entanto, que a geração mais antiga de poetas, da qual se destaca a figura de Ésquilo, ensaiava os seus próprios coros e inventava as danças ${ }^{31}$. O sucesso dependia do chorodidaskalos mas também, em grande parte, do corego, ou melhor, da sua disponibilidade para gastar dinheiro.

Um passo de Lísias (Defesa contra a acusação de suborno, 1-2) demonstra que as estimativas apontavam para um custo de cinquenta minas para um coro de homens e de quinze para um de rapazes. Os coros trágicos custariam cerca de trinta e os cómicos à volta de dezasseis minas.

Demóstenes (Contra Midias, 156) refere que um coro ditirâmbico de homens era mais dispendioso do que um coro trágico, uma vez que o número de elementos era superior naquele e talvez também por causa da ostentação que os coros ditirâmbicos costumavam exibir.

$\mathrm{O}$ corego mais bem sucedido recebia uma trípode ${ }^{32}$, que era erigida num monumento (por isso chamado corégico) e cujas despesas de construção ele próprio suportava ${ }^{33}$. No tempo de

${ }^{30}$ Cf. Belessort (1934: 37).

${ }^{31}$ Vide Ateneu, Deipnosofistas, 21d-22a.

${ }^{32}$ As trípodes eram erigidas numa estrada específica que conduzia ao teatro pela zona este. A procissão que se desenrolava por este caminho sagrado era um evento muito importante, no qual a pólis ostentava a sua identidade e a sua estrutura. O corego desfilava na procissáo coroado e com vestes riquíssimas. Cf. Pickard-Cambridge (1953: 78-79).

${ }^{33}$ Vide monumento de Lisícrates de 334 a.C. (I.G. 2.3042), o único que sobreviveu e do qual consta a seguinte inscrição: "Lisícrates, filho de Lisitides de Cícina, foi o corego. A tribo de Acamante ganhou o coro de rapazes. Téon tocou flauta. Lisíades, o Ateniense, encenou. Evéneto foi o arconte». 
Demóstenes (Contra Midias, 63), o corego vitorioso era coroado no teatro.

Outra das funçóes que competia ao arconte-epónimo (e no período helenístico ao agonothetes) era a seleção dos poetas a concurso $^{34}$, os quais se dirigiam a esta figura, recitando-lhe parte do seu trabalho ${ }^{35}$ e solicitando-lhe um coro, sendo que o arconte, por si só, podia aceitar ou recusar. Para esta escolha não são conhecidos os critérios, mas sabe-se que a idade não influenciava a decisão e que, por isso, Sófocles, por exemplo, produziu a sua primeira peça aos 28 anos de idade, Eurípides aos 26 e Aristófanes, em seu próprio nome, aos 2036; e que, provavelmente, um poeta poderia ser excluído por ter demonstrado uma fraca prestaçáo no concurso do ano anterior. Por outro lado, com o acréscimo de importância da tragédia, um dos poetas passou a ser selecionado automaticamente, enquanto vencedor das competiçóes ocorridas no ano transato ${ }^{37}$.

Este era sem dúvida o festival mais importante do mundo grego, não só pela qualidade dos concursos dramáticos, mas também pelo facto de ser um evento aberto a todo o espaço helénico ${ }^{38}$. Como as Grandes Dionísias decorriam no mês Elafebólion, ou seja, nos finais de março, o mar apresentava-se navegável, o que facilitava a deslocação de estrangeiros, inclusivamente bárbaros, que ocorriam a Atenas por questóes de otium ou de negotium. O evento revestia-se de uma tal importância, que até alguns prisioneiros eram libertados nesses dias para que pudessem assistir às performances ${ }^{39}$. Também o número de pessoas que estavam envolvidas neste festival era bem evidente da importância que o mesmo assumia. Assim, no total e anualmente, participavam, nas performances das

${ }^{34}$ Esta situação verificava-se também nas Leneias.

${ }^{35}$ Cf. Rehm (1992: 24).

${ }^{36}$ Aristófanes produziu anteriormente três peças sob o pseudónimo de Calístrato.

37 Rehm (1992: 24) acredita que Eurípides não terá tido dificuldades em ser selecionado sempre que se auto-propôs a apresentar uma tetralogia.

38 Zimmermann (1991: 9) defende que a politização das Grandes Dionísias, no final do século VI a.C., ajuda a explicar a importância dos festivais no século seguinte, o da democracia. É que, depois das guerras Persas, transformaram-se no instrumento político por excelência, já que o esplendor do festival era uma forma de exaltar os atenienses face aos povos estrangeiros que se deslocavam a Atenas para assistir ao evento.

${ }^{39}$ Há relatos que evidenciam que, em algumas ocasióes, a presença nos festivais possibilitou a fuga de cativos. 
Grandes Dionísias, mais de 1250 artistas, número que resultava do facto de, para os ditirambos, serem necessários vinte poetas, vinte coregos, vinte flautistas, quinhentos homens e quinhentos rapazes; para a tragédia, três poetas, três coregos, três flautistas, nove atores ${ }^{40}$ e entre trinta e seis a quarenta e cinco coreutas ${ }^{41}$; para a comédia, cinco poetas, cinco coregos, cinco flautistas, quinze atores e cento e vinte coreutas. Para a concretização das performances, contribuía também um conjunto alargado de outras pessoas relacionadas com a confeção do vestuário ou com a assistência técnica.

No primeiro dia do festival, o oitavo do mês Elafebólion, um dia preparatório, decorria o proagon, num edifício perto do teatro, denominado odeon. Os poetas a concurso que se faziam acompanhar pelos atores e pelos elementos do coro, que se apresentavam sem máscaras ou figurinos mas coroados de flores, ascendiam a uma plataforma e davam uma preleção sobre as composiçôes que estavam prestes a exibir. ${ }^{42}$

No final do dia tinha lugar a eisagoge de Diónisos apo tes escharas. Este ritual consistia numa reconstituição do advento do deus desde Eleutherai, na Beócia, até à Ática. Assim, a estátua de Dionysos Eleuthereus, que comummente retrata o deus com um bastão de madeira e uma máscara e que nesse dia surgia coroada com heras, era conduzida do seu templo na Acrópole para outro templo nas imediaçóes da Academia ${ }^{43}$, na estrada para Eleutherai, e era colocada no altar de sacrifícios - eschara. Seguiam-se oblaçóes e entoaçóes de hinos. Depois, a estátua era levada para o teatro numa procissáo de tochas e na parte mais importante do ritual era transportada pelo ephebos - o homem mais novo em idade militar. Pickard-Cambridge (1953: 587) refere que se desconhece se a estátua permanecia no teatro até ao fim do festival ou se regressava ao templo para a preparação dos sacrifícios que a pompe exigia, voltando, depois, para o teatro. De qualquer forma, e tendo por base o testemunho de

${ }^{40}$ Número que podia aumentar, no caso de o poeta recorrer a figurantes.

${ }^{41} \mathrm{O}$ número dependia de os coros serem constituídos por doze ou quinze elementos.

42 Cf. Ésquines, Contra Ctesifonte, 67; Aristófanes, Rãs, 1099-1118. Houve, no entanto, uma ocasião em que os elementos do coro, acompanhados por Sófocles, participaram no proagon despojados de coroas de flores - depois da notícia da morte de Eurípides. Cf. Vida de Eurípides, apud Csapo \& Slater (1994: 110).

${ }^{43}$ Cf. Pausânias, 1.29.2. 
Aristófanes (Rãs, 809-812) e Filóstrato (Vida de Apolónio, 4. 22), o autor admite a sua presença durante as performances.

$\mathrm{Na}$ manhá do dia seguinte ${ }^{44}$, tinha lugar a pompe, um cortejo religioso que culminava com sacrifícios no recinto sagrado de Diónisos. Imolava-se o touro, conduzido na procissão pelo ephebos, eram oferecidas outras vítimas e, inclusivamente, vasos.

O percurso da pompe é desconhecido mas sabe-se que todos os estratos sociais de Atenas estavam representados e que o cortejo era liderado por uma virgem - a kanephoros -, pertencente à aristocracia, que transportava um cesto de oiro, contendo os primeiros frutos para o sacrifício ${ }^{45}$. Os coregos desfilavam também sumptuosamente vestidos. Seguiam-se centenas de outros sacrifícios e, no final do cortejo, grupos de homens cantavam hinos, sustentando grandes falos, e executavam danças nos altares.

$\mathrm{Na}$ tarde do mesmo dia e provavelmente até à noite, decorria o concurso de cantos corais ${ }^{46}$. Qualquer uma das dez tribos fazia-se representar por um corego ${ }^{47}$, por um coro ditirâmbico de 50 jovens e por um outro de 50 homens ${ }^{48}$. Cada uma das performances demorava cerca de 30 minutos. O corego vencedor de cada uma das competiçóes era galardoado com uma coroa e uma trípode e, provavelmente, o poeta vencedor recebia um touro para sacrificar a Diónisos. Ambos eram conduzidos a casa num cortejo vitorioso - o komos. Pickard-Cambridge (1953: 79) fala-nos de dois grandes períodos na história dos ditirambos em Atenas. Um deles na primeira parte do século V a.C. - o tempo de Simónides, Píndaro e Baquílides. Nesta altura, a poesia era do mais alto mérito literário e a música subordinava-se a ela. $\mathrm{O}$ outro período vai até meados do século IV a.C. e é caracterizado por uma predominância da flauta e da música elaborada em detrimento das palavras - o tempo de Melanípides, Frínis, Cinésias e Timóteo. A partir desta altura,

${ }^{44} \mathrm{Na}$ visão de Csapo \& Slater (1994: 105), a pompe desenrolava-se no $10^{\circ} \mathrm{dia}$.

${ }^{45}$ Vide escólio a Aristófanes, Acarnenses, 242a.

46 Este concurso, posterior às reformas de Clístenes, parece ter sido uma forma de consolidar a reorganização das tribos atenienses. Cf. Csapo \& Slater (1994: 106-107).

${ }^{4}$ Desconhece-se como é que cada tribo escolhia o seu corego, mas sabe-se que a escolha era feita um mês antes do festival. Cf. Aristóteles, Constituição de Atenas, 56.3.

${ }^{48}$ Cf. escólio a Ésquines, Contra Timarco, 10. 
não foi distinguido o nome de nenhum poeta, sendo apenas mencionados os nomes dos flautistas.

Os dias subsequentes eram dedicados às competiçóes dramáticas, cuja realização remonta à época de Pisístrato, já que a data conhecida da primeira representação trágica em Atenas é de cerca de 534 a.C. ${ }^{49}$.

A ordem das competiçóes dramáticas bem como os dias a elas dedicados continuam a ser questóes controversas. A versão dominante é a de que, antes e depois da guerra do Peloponeso (431-404 a.C.), o primeiro dia dos concursos era dedicado à performance de cinco comédias e os restantes três eram preenchidos, cada um deles, com a apresentação, por um único poeta e corego, de três tragédias $s^{50}$ e um drama satírico ${ }^{51}$. Outra das versóes dá como certo que o primeiro dia estava reservado à performance dos ditirambos de rapazes e à representação de uma comédia, o segundo à competição dos coros ditirâmbicos de homens e à performance de outra comédia, e os três últimos dias, cada um deles, à apresentação de uma tetralogia trágica e de uma comédia.

Durante a guerra do Peloponeso e tendo em conta as hypotheseis às peças de Aristófanes, Nuvens (Dionísias, 423 a.C.), Paz (Dionísias, 421 a.C.) e Aves (Dionísias, 414 a.C.) que nomeiam apenas o primeiro, o segundo e o terceiro lugares na competição, parece que eram produzidas, por questóes económicas, apenas três comédias. Assim, acredita-se que, durante três dias, eram apresentadas de manhã três tragédias e um drama satírico e à tarde uma comédia. Também das Aves de Aristófanes (vv. 786-789) se conclui esta distribuição: "Está farto dos coros trágicos, dá-lhe a fome, levanta voo e vai até

${ }^{49}$ Cf. Mármore de Paros, FGrHist 239.54-55, 58, 61.

50 Segundo Harsh (1944: 23), no tempo de Ésquilo, parece que era prática comum os poetas relacionarem as três tragédias apresentadas em termos temáticos. Exemplo disso é a Oresteia de Ésquilo - a única trilogia completa preservada, composta pelas peças Agamémnon, Coéforas e Euménides - e a tetralogia das Danaides, constituída pelas Suplicantes, os Egipcios, as Danaides e Amimone.

${ }^{51}$ A lei de Evégoros (cf. supra n. 7) refere que as tragédias eram apresentadas antes das comédias nas Leneias e as comédias antes das tragédias nas Dionísias. No entanto, a ordem podia ser alterada. Quando as peças antigas eram representadas separadamente ou quando o número de peças a concurso variava, naturalmente que o calendário seria também modificado. 
casa almoçar; mais tarde, já com a barriguinha cheia, volta a voar a tempo da nossa comédia." 52

A competição abria com uma série de cerimónias. Primeiramente, tinha lugar um ritual de purificação do teatro, protagonizado por pessoas chamadas peristiarchoi ou periestiarchoi que derramavam o sangue de um leitão ${ }^{53}$ para sacralizar o espaço.

Seguiam-se as libações, executadas pelos dez generais, os oficiais eleitos mais importantes no Estado ateniense ${ }^{54}$. Depois, $\mathrm{o}$ arauto anunciava o nome de cidadãos que se distinguiam e os benfeitores do Estado, os quais eram agraciados com coroas de ouro pela Assembleia. Posteriormente ocorria uma parada, onde se exortavam as crianças órfâs de soldados que haviam perecido em batalhas ao serviço de Atenas ${ }^{55}$. Eram também mencionados os nomes dos escravos que haviam conseguido o estatuto de libertos.

Seguidamente, selecionavam-se os juízes que decidiam entre si a ordem de aparecimento dos concorrentes. A escolha do júri obedecia a critérios rigorosos de forma a assegurar a justiça da competição. Alguns passos de oradores como Isócrates (Trapezitico, 33-34) evidenciam que, antes do festival, a Assembleia apresentava uma lista de nomes selecionados de cada uma das dez tribos ${ }^{56}$, os quais eram depositados em dez urnas, sendo que cada urna correspondia a uma tribo. As urnas, seladas depois pelo prítane, que presidia à assembleia, e pelos coregos, eram guardadas no tesouro público, na Acrópole, sendo considerada uma ofensa capital a sua abertura ilícita. Posteriormente, no início das competiçóes, as dez urnas eram colocadas no teatro e o arconte retirava um nome de cada uma. Os dez eleitos juravam exprimir um veredito imparcial. No final do concurso, cada juiz escrevia numa tabuinha a ordem classificativa. Estas tabuinhas eram depois colocadas dentro de uma urna e o arconte retirava cinco delas, pelo que o veredito resultava, assim, das classificações atribuídas nessas cinco

${ }^{52}$ Tradução de Maria de Fátima Sousa Silva (Lisboa, Ediçôes 70, 1989).

${ }^{53}$ Cf. Pólux, 4.104.

${ }^{54}$ Cf. Plutarco, Vida de Cimon, 8.8.

${ }^{5}$ Cf. Isócrates, Sobre a Paz, 82.

${ }^{56}$ Desconhecem-se os critérios dessa seleção, mas um dos passos que demonstra que o júri era selecionado tendo em conta as dez tribos, está presente em Plutarco (Vida de Cimon, 8.7-9), onde se afirma que os generais eram ótimos candidatos a júri porquanto representavam as dez tribos. 
tabuinhas ${ }^{57}$. Pretendia-se desta maneira, de alguma forma, neutralizar qualquer avaliação mais parcial, já que os juízes eram muitas vezes influenciados pela audiência ${ }^{58}$.

$\mathrm{O}$ arauto proclamava o nome dos poetas vencedores e estes eram coroados pelo arconte com uma grinalda de heras e conduzidos a casa num cortejo vitorioso - komos ${ }^{59}$. Desconhece-se qual o prémio atribuído ao melhor ator.

Náo se sabe se o júri era fixo para os três concursos do festival nem até que ponto os juízes podiam ser influenciados por medo de represálias, mas o grande número de vitórias de Ésquilo e Sófocles é prova evidente de que o júri demonstrava uma grande capacidade crítica.

Aristófanes (Mulheres na Assembleia, 1154-1159) sugere que as hipóteses de vitória de um poeta dependiam também da ordem determinada pela sorte em que o mesmo aparecia em competição. Assim, segundo ele, a expectativa era a de que a última peça a ser representada, a que ficava mais presente na memória dos espectadores e do júri, fosse a que tivesse mais probabilidades de ganhar, e vice-versa.

Durante o século V a.C. e, provavelmente, ainda no século IV, cada poeta trágico a concurso apresentava quatro peças, sendo que uma delas era normalmente um drama satírico. Depois de 341 a.C. havia uma única performance de uma peça satírica e cada poeta apresentava apenas três composiçóes. Por esta altura era também usual a representação de uma tragédia antiga $^{60}$, antes da competição das tragédias novas. Relativamente à comédia, este género só obteve o reconhecimento do Estado mais tarde do que a tragédia, pelo que, até essa altura, eram os próprios poetas a concurso que suportavam todas as despesas inerentes à sua apresentação. A primeira vitória duma comédia

${ }^{57}$ Cf. Zenóbio, 3.64.

${ }^{58}$ Platâo, Leis, 2.659a.

59 Platão (Banquete, 175e) dá-nos o retrato da celebração privada que acompanhou a vitória trágica de Ágaton em 416 a.C.

${ }^{60}$ A primeira performance de uma tragédia antiga nas Grandes Dionísias data de 386 a.C. No século V a.C., as tragédias antigas que eram apresentadas nestes festivais eram aquelas que, depois do fracasso noutras apresentaçóes, tinham já sido revistas. 
apresentada sob a égide desse reconhecimento data de 486 a.C. e foi atribuída a Quiónides ${ }^{61}$.

Cada comediógrafo a concurso apresentava apenas uma peça e sabe-se que eram cinco os poetas em competição, exceto, como já foi dito anteriormente, durante a guerra do Peloponeso, altura em que concorriam apenas três. Tal como aconteceu com a tragédia, também a partir de 339 a.C. começaram a ser representadas comédias antigas e esta prática manteve-se até ao século I da era cristá. No entanto, acredita-se que a partir do século II a sua popularidade começasse a decrescer e certos autores, como Reisch apud Pickard-Cambridge 1953: 84), defendem que a apresentação das comédias passou a ser trienal e não anual, pelo facto de em quatro locais as inscrições omitirem os resultados de dois anos seguidos.

No tempo de Téspis, era o próprio poeta que trabalhava como ator nas peças por si produzidas. Ésquilo terá, provavelmente, atuado antes de ter introduzido um segundo ator. Depois, os poetas começaram a contratar profissionais ${ }^{62}$.

Mais tarde ${ }^{63}$ e possivelmente pelo facto de se ter introduzido a atribuição de prémios aos atores, passou a ser da responsabilidade do Estado, presumivelmente do arconte, a escolha dos três protagonistas de cada uma das tragédias, para evitar a conflituosidade entre poetas que seguramente pretenderiam aquele que melhor os representasse, o que é bastante ilustrativo da importância que os atores começaram a assumir em detrimento dos poetas ${ }^{64}$.

Quem recebia o prémio de melhor ator era convidado a ser um dos protagonistas no ano seguinte. Estes protagonistas passaram, posteriormente, a representar uma tragédia de cada um dos poetas, já que não seria justo que, dado que os poetas passaram a ser menos populares do que os atores, o melhor ator

${ }^{61}$ Cf. Suda, s.v. Chionides.

${ }^{62}$ Ésquilo, por exemplo, contratou Cleandro e depois Minisco como segundo e terceiro atores; Sófocles, Tlepólemo; Eurípides, Cefisofonte; Cratino, Crates; Crates, Ferécrates. Cf. Pickard-Cambridge (1953: 93-94).

${ }^{63}$ Nas Grandes Dionísias, provavelmente, em 449 a.C. e, nas Leneias, talvez em 430 a.C.

${ }^{64}$ Aristóteles, Retórica, 3.1. 
desempenhasse o papel de protagonista nas três tragédias de um só poeta, o que lhe conferiria vantagem sobre os outros ${ }^{65}$.

Apenas aos protagonistas podia ser atribuído o prémio de melhor representação mas, como afirma Pickard-Cambridge (1953: 96), não quer isto dizer que o prémio fosse, necessariamente, atribuído ao ator que representava na peça mais bem sucedida. Por exemplo, quando o prémio de melhor ator foi atribuído a Calípides, a tragédia que alcançou a vitória foi a de Lisícrates, na qual o ator não havia representado ${ }^{66}$. Relativamente à seleção do segundo e terceiro atores, desconhece-se a forma como esta ocorreria, mas sabe-se que estaria a cargo do poeta ${ }^{67}$.

Quanto à comédia, há menos certezas relativamente ao método de seleção dos atores, mas Pickard-Cambridge (1953: 94) sugere que, provavelmente, um dos cinco protagonistas selecionados fosse o vencedor dos Chytroi nas Antestérias. De qualquer forma, cabia aos poetas, no seu conjunto, decidirem qual deles os representaria.

No dia imediatamente a seguir à conclusão do festival (o $14^{\circ}$ dia do mês Elafebólion, o $13^{\circ}$ durante a guerra do Peloponeso), tinha lugar a festividade em honra de Zeus conhecida por Pandia, e no dia subsequente ocorria uma assembleia especial no teatro ${ }^{68}$. O primeiro dever desta assembleia era avaliar a conduta dos oficiais responsáveis pelo festival; seguiam-se as probolai - a citação em tribunal de transgressores da lei ou da santidade dos festivais.

${ }^{65}$ Se consultarmos a inscrição I.G. 2.2320, podemos constatar que no ano 341 a.C., quando Astídamas, Evaresto e Afareu competiram cada um com três tragédias às Grandes Dionísias, todos eles foram representados por três atores (Téssalo, Neoptólemo e Atenodoro) nas suas peças.

${ }^{66}$ Cf. I.G. 2.2319 col. ii (Didaskaliai das tragédias representadas nas Leneias, entre 420-417 a.C.).

${ }^{67}$ Cf. Taylor (1978: 22).

${ }^{68}$ Cf. Demóstenes, Contra Midias, 8-10. 
2 - Edifício Teatral 
(Página deixada propositadamente em branco) 
As origens do teatro, na Grécia, estão intimamente relacionadas com a vertente religiosa tão presente no pensamento grego. Para isso concorre, em primeiro lugar, o facto de os jogos cénicos terem resultado do culto dedicado ao deus Diónisos. Mesmo aquando dos festivais, altura em que a arte da representação estava já amplamente enraizada, ocorriam cerimónias em honra do deus que envolviam, entre outros eventos, rituais de sacrifício em altares próprios. O facto de mesmo nos teatros helenísticos, séculos mais tarde, existir um altar dedicado a Diónisos é um resquício dessa mesma função religiosa que começou por caracterizar o teatro grego.

O mais antigo teatro de pedra conhecido na Ática é o de Tóricos, um dos muitos demos gregos que acolhiam as Dionísias Rurais. Através das ruínas que subsistiram é possível perceber que a linha central dos lugares era reta e curvada nas partes laterais ${ }^{1}$, o que para muitos estudiosos ${ }^{2}$ é uma prova de que, inicialmente, a orquestra, o local destinado às danças, seria retangular e náo circular, como a que se encontra em Atenas, no teatro em pedra de Diónisos do século IV a.C. Esta disposiçáo da orquestra e consequentemente dos lugares, na opiniáo de Wiles (2003: 65), proporcionaria uma visão mais ampla do clímax da procissáo - que saía do porto e terminava no templo de Diónisos - aos cerca de 3.000 espectadores que se sentavam no auditório. Desta forma, era também possível visualizar-se aqueles que apresentavam os seus animais ao deus no templo, que ficava do lado direito da audiência, e os que os sacrificavam, do lado esquerdo, no altar. Por outro lado, o facto de a área de atuação medir cerca de 30 metros causava graves problemas de visualização e, por isso, o mesmo estudioso (Wiles 1997: 33) considera que, apesar de haver vários registos de performances dramáticas neste espaço, a área reservada à

${ }^{1} \mathrm{Na}$ opinião de Wiles (1997: 33), esta configuração proporcionava uma boa acústica.

${ }^{2}$ Camp (2001: 145-146) acrescenta que esta disposição da orquestra seria também a que se poderia encontrar noutros teatros de outros demos gregos. É o caso do teatro de Euónimon, de Ramnos e mesmo de Icárion. Por essa razáo, e pelo facto de os assentos do teatro de Diónisos do século $\mathrm{V}$ a.C. que perduraram serem a direito em vez de arredondados, o autor acredita que as orquestras circulares podem ter resultado de um desenvolvimento tardio e que, originalmente, estas seriam retangulares. 
representação parecia naturalmente mais apropriada a danças corais ou a procissóes.

Para além das performances teatrais, este edifício, tal como acontecia noutros teatros de outros demos gregos, poderia acolher também as assembleias políticas, e de tal forma se desenvolveu esta associação entre teatro e política - que, aliás, sempre se fez sentir em todo o espaço helénico - que, como nos recorda Wiles (1997: 36), situações houve em que foi notória a promiscuidade destes dois mundos. Assim, por exemplo, Demétrio da Macedónia desfilou em palco como se fosse um ator trágico, quando submeteu os Atenienses através de uma exibição parateatral de autoridade, o que levou à alteração, durante alguns anos, do nome de Festival de Diónisos para Festival de Demétrio.

Esta relação político-cultural, visível no teatro de Tóricos, instituiu-se também em Atenas, uma vez que se afigura provável que o teatro terá começado por ter lugar na Ágora ${ }^{3}$, o local que primordialmente servia os interesses públicos, religiosos, culturais e, só numa fase posterior, veio a cumprir também uma função comercial.

Fontes desconhecidas, compiladas por lexicógrafos, explicam o termo grego para lugares sentados $\left(i k r i a^{4}\right)$ como estritamente relacionado com os assentos de madeira existentes na Ágora, de onde, presumivelmente, os espectadores assistiriam aos concursos dramáticos, e identificam a palavra orchestra com o lugar que, no mesmo local, estava destinado às danças. No entanto, sabe-se hoje que a antiga Ágora estaria situada no nordeste da Acrópole e, segundo Wiles (2003: 96), terá sido provavelmente aqui e não no edifício clássico que a comédia e a tragédia começaram por ser representadas 5 .

A transição do espaço de representação da Ágora para o recinto onde estava construído o templo de Diónisos ${ }^{6}$ ter-se-á ficado a dever, segundo fontes antigas ${ }^{7}$, ao facto de os assentos

${ }^{3}$ Segundo Bieber (1961: 54), desde o tempo de Pisístrato e seus filhos, quando Téspis veio para Atenas, em 534 a.C.

${ }^{4}$ Cf. Fócion, s.v. ikria.

5 Bieber (1961: 54) defende que a Ágora situar-se-ia, provavelmente, no local onde mais tarde Agripa mandaria construir o odeon.

${ }^{6}$ Travlos (1971: 537) defende que o recinto de Diónisos foi usado, em primeira instância, para as danças corais e que só posteriormente o drama foi transferido da Ágora para este local.

${ }^{7}$ Suda, s.v. Pratinas. 
de madeira terem ruído, durante uma performance, no início do século V a.C. ${ }^{8}$ Por esta altura, foi também construído um novo espaço para as assembleias políticas - a Pnix - numa colina próxima da Acrópole, verificando-se a partir de então a separação do espaço cívico das outras vertentes sociais, ficando apenas reservado à Ágora o comércio e a política?

Esta separação do teatro e da vida política não foi, no entanto, definitiva, já que mais tarde, com a crescente melhoria das condiçóes acústicas dos teatros, as assembleias passaram a desenrolar-se nestes locais por toda a Grécia.

Com o desmoronamento das bancadas na Ágora, os concursos teatrais passariam, então, a efetuar-se na encosta sul da Acrópole, que proporcionava excelentes condiçôes acústicas, no local onde primordialmente terá existido um altar sacrificial e depois o templo de pedra suavemente porosa dedicado a Diónisos ${ }^{10}$, que albergava a estátua do deus trazida de Eleutherai. Aqui decorreriam as cerimónias que começavam ao pôr do sol e eram dirigidas por um sacerdote que, juntamente com a estátua do deus, se posicionava face ao sol nascente.

A audiência sentava-se na encosta da Acrópole ${ }^{11}$, em bancos de madeira, numa área curva, um pouco maior do que um semicírculo, no local que acabou por ser designado de theatron, para assistir aos sacrifícios e às danças executadas em frente ao altar, na orchestra, que se passou a chamar assim por ser o lugar que permitia ver o coro dançar.

No início do dia das performances espargia-se vinho sobre a orquestra e derramava-se o sangue de um leitáo para sacralizar

${ }^{8}$ Segundo Bieber (1961: 54), aquando da 70a Olimpíada, em 499-496 a.C., a vivacidade dos gestos e dos movimentos entusiásticos dos espectadores em muito terá contribuído para este facto. Pickard-Cambridge (1946: $14)$, no entanto, refere que esta data não é fiável, porquanto a Suda apenas assegura que o espaço ruiu aquando de uma performance de Pratinas, mas não menciona qual. De qualquer forma, o autor defende que esta situação terá ocorrido num dos anos das três primeiras décadas do século $\mathrm{V}$ a.C.

${ }^{9}$ Cf. Wiles (2003: 97).

${ }^{10}$ Segundo Bieber (1961: 54), este templo terá sido erigido em meados do século VI a.C. e seria, presumivelmente, decorado com representaçóes de danças báquicas ou de sátiros. Connor acredita que a estátua do deus terá vindo para Atenas quando Eleutherai passou do domínio tebano para o ateniense, aparentemente nos inícios do século $V$ a.C., e sugere que o templo seja também dessa altura. Apud Wiles (1997: 54).

${ }^{11}$ Mais tarde, os espectadores passaram a dispor-se nas partes laterais da encosta de forma a obterem um melhor ângulo de visão. 
o espaço. A procissão dionisíaca ${ }^{12}$ chegava ao teatro pelo lado esquerdo da audiência, depois de ter passado pela rua das Trípodes - os monumentos comemorativos de vitórias, erigidos a expensas dos coregos vencedores - e culminava, na orquestra, com o desenrolar das danças circulares - os ditirambos - de cada uma das dez tribos.

No centro desta orquestra primitiva, que Dörpfeld ${ }^{13}$ reconstruiu como sendo circular e com um diâmetro de cerca de 27 metros, ficava a thymele $e^{14}$ - o altar sacrificial em pedra - e, próximo dela, estava posicionada a estátua do deus que, tradicionalmente, era retirada do templo para assistir às performances.

Wiles defende que a relação entre o espaço das performances trágicas e o espaço reservado ao sacrifício tinha uma grande importância simbólica, porquanto o sacrifício era também uma outra espécie de realização dramática, e exemplifica com a Oresteia, nomeadamente com o caso de Agamémnon, Cassandra e Clitemnestra, que são vistos, um de cada vez, como vítimas sacrificiais, e cujo morticínio é executado por detrás da skene - um edifício traseiro -, fora do alcance da vista dos espectadores. Como a área de representação ficava entre o templo de Diónisos e o altar a ele dedicado, a passagem das personagens, através da skene - como se fossem dirigir-se a este último local - e o cheiro do sangue dos animais que estavam

${ }^{12}$ Wiles (1997: 26) acredita que esta cerimónia seria o ponto central das Dionísias Rurais e que as performances teatrais, por esta altura, não passariam de uma adenda.

${ }^{13}$ Csapo \& Slater (1994: 79) afirmam que hoje são muitos os que duvidam da configuração proposta por Dörpfeld, até porque são significativas as evidências que vão surgindo e que apontam no sentido de as orquestras clássicas noutros teatros serem retilíneas ou trapezoidais. Assim, e a título de exemplo, Dinsmoor atribui-lhe um diâmetro menor e acredita que a orquestra teria uma forma poligonal; Fiecher considera que o diâmetro do círculo náo seria muito maior do que o dos antigos locais reservados à dança; Anti é de opinião que a orquestra seria retangular. Apud Bieber (1961: 55; 63). Travlos (1971: 361), no entanto, segue a tese defendida por Dörpfeld e advoga a legitimidade da orquestra circular, uma vez que a performance dos ditirambos, conhecidos como coros circulares, era o evento mais tardio e o primeiro das Dionisíacas.

${ }^{14}$ Wiles (1997: 70) considera que a thymele pode ter servido como foco da atividade ritual, nomeadamente, nas danças circulares dos ditirambos, na oferenda de libaçóes e na purificaçáo do teatro pelos periestiarchoi, os encarregados de espargir o sangue do leitão. 
realmente a ser sacrificados conferia mais verosimilhança às mortes encenadas fora do alcance da vista dos espectadores.

Esta skene principiou por ser um edifício em madeira e temporário ${ }^{15}$, que assumia uma dupla função, porquanto, internamente, funcionaria como local de arrumos e como camarim $^{16}$, usado pelos atores para a mudança de vestuário ${ }^{17}$; externamente, servia de estrutura suscetível de representar um determinado cenário que, segundo Bieber (1961: 59), seria facilmente alterado durante as interrupçóes entre as quatro peças de uma tetralogia ou durante a noite, entre os dias de festival ${ }^{18}$. Além disso, proporcionava aos espectadores a ilusão de que a ação podia ocorrer fora do alcance da sua vista.

A primeira produção que necessitou de grandes edifícios, um templo e um palácio, foi a Oresteia de Ésquilo, em 458 a.C. ${ }^{19}$, e é por esta razão que é comummente aceite que a introdução da skene terá ocorrido aquando da apresentação desta tragédia esquiliana ${ }^{20}$.

Sófocles é apresentado por Aristóteles (Poética, 4.1449a 18) como tendo sido o primeiro cenógrafo. Os cenários por

${ }^{15}$ Wiles (1997: 161) acredita que a skene temporária não estaria no local no dia das danças circulares e dos sacrifícios, já que a audiência haveria de querer ter uma visão dos sacrifícios tribais que eram o natural culminar das danças ditirâmbicas.

${ }^{16}$ Acerca da conceção da skene como skenotheke, cf. Bieber (1961: 59). D'Arnott (1989: 3), tendo em conta que literalmente skene significa 'cabana' ou 'tenda', acredita que, nos primeiros tempos do teatro, esta estrutura cumprisse realmente essa função e mais não fosse do que um camarim, um local de onde os atores podiam fazer a sua entrada em cena e, talvez, um espaço onde podiam aquecer a voz.

17 Inicialmente, não existiria qualquer estrutura traseira e os atores vestir-se-iam provavelmente no bosque, uma vez que as longas partes cantadas do coro proporcionavam-lhes tempo suficiente para mudarem de roupa; mas depois houve necessidade de facultar condiçóes para que a execução dessa tarefa fosse mais rápida, já que, nas últimas peças de Ésquilo e em Sófocles, as intervençóes do coro passaram a ser de menor duração e importância.

${ }^{18}$ Pickard-Cambridge (1946: 123) considera que a alteração dos cenários passou a ser vista como uma rotina e que por isso podia ocorrer diante dos olhos dos espectadores, sem que isso lhes ferisse a sensibilidade.

${ }^{19}$ As peças anteriores a esta requeriam simples adereços, como altares, pedras ou túmulos, que podiam facilmente ser colocados na orquestra.

${ }^{20}$ Esta opinião é partilhada por Matino (1998: 150), que afirma que naquele ano a skene assumiu uma forma definitiva e assim se pôde falar em representaçóes dramáticas da vivência humana sobre um fundo cenográfico. 
ele criados e denominados por Pólux (4.126 sqq., 131) de katablemata consistiam em telas, fixadas na skene, e pintadas de forma muito simples, pelo que náo deveriam exibir mais do que o início da perspetiva e da ilusão cénica que se pretende atingir com a conceção de um cenário. No entanto, convém náo esquecer que o teatro grego era o teatro da palavra por excelência e, por isso, na opinião de D’Arnott (1989: 136), o cenário funcionava, tal como as máscaras dos atores, como uma tela em branco onde o poeta desenhava o que pretendia que os espectadores visualizassem, através de uma linguagem evocativa.

Vitrúvio (5.6.9) dá-nos conta da distinção entre cenários trágicos, cómicos e satíricos, e fala-nos da scaena ductilis ${ }^{21}$, que consistia numa larga tela pintada e fixada à skene. Várias scaenae ductiles podiam ser colocadas, umas em cima das outras, na skene, de tal forma que a mudança de cenário requerida por uma outra peça era facilmente executada, porquanto, ao retirar-se a primeira scaena ductilis, de imediato se vislumbraria a outra ${ }^{22}$.

Os katablemata podiam também ser fixados nos flancos da skene e, neste caso, denominavam-se de periaktoi ${ }^{23}$. Segundo Vitrúvio (5.6.8) e Pólux (4.126 sq., 130 sq.), eram de madeira e tinham a forma de prisma, sendo que cada um dos lados

Embora defendam também esta posição, Csapo \& Slater (1994: 79) acreditam, no entanto, que a grande remodelação do teatro só terá ocorrido, provavelmente, na segunda metade do século $\mathrm{V}$ a.C.

${ }^{21}$ Bieber (1961: 74) coloca a hipótese de no período clássico a scaena ductilis ter a designaçáo de proscénio, uma vez que Antífanes (apud Ateneu, Caipnosofistas, $13.587 \mathrm{~b}$ ) compara Nânion a um proscénio porque ela tinha uma cara fabulosa, roupas caras e ouro, mas, quando nua, era invulgarmente feia, ou seja, também o proscénio ou scaena ductilis, ao ser retirado, deixaria à vista o esqueleto de madeira - a skene temporária. Esta situação explicaria a existência do proscénio no século $\mathrm{V}$ a.C. não enquanto palco, mas enquanto adereço imprescindível do cenário.

${ }^{22}$ Segundo Bieber (1961: 74-75), um dos testemunhos que evidencia o uso desta prática no séc. IV a.C. é o teatro de Megalópolis.

${ }^{23}$ Embora não haja vestígios da utilização de periaktoi no período anterior à Época Helenística, Bieber (1961: 75) considera que este parece ser um procedimento tâo simples e apropriado a um teatro ao ar livre que não há qualquer razão para não aceitar como provável a sua ocorrência no teatro clássico. Pickard-Cambridge (1946: 126-7) coloca, no entanto, muitas dúvidas sobre a sua utilização no período clássico. 
representava um cenário diferente. Ao fazer-se rodar o prisma, de imediato se alterava o cenário.

Convencionalmente, quando se pretendia indicar uma localidade diferente na mesma cidade, mudava-se, apenas, o periaktos direito; para alterar toda a cena, eram virados os dois. As entradas laterais do teatro - as parodoi ${ }^{24}$-, que ficavam próximas de cada um dos lados ou em frente dos periaktoi, tinham o mesmo tipo de significado simbólico. Era através das parodoi que os atores e o coro faziam a sua entrada na orquestra. Para além destas duas possibilidades, havia também como alternativa uma porta central na skene e, provavelmente, mais duas pequenas portas de cada um dos $\operatorname{lados}^{25}$. A porta do meio, representativa do edifício mais distinto e importante, era sempre ricamente decorada.

As entradas e saídas de cena das personagens obedeciam a convençóes estipuladas. Joerden argumenta, em concordância com Pólux, que a cidade, na tragédia, devia estar localizada à direita da audiência, e o campo à esquerda ${ }^{26}$.

Do que não há dúvida é de que as duas parodoi funcionavam sempre como oposiçôes binárias, pelo que é evidente a carga analógica, metafórica e simbólica que a entrada das personagens fazia transparecer. Assim, e tendo em conta o pensamento grego da altura ${ }^{27}$, à que conduzia a personagem para a orquestra pela direita da audiência estavam associados símbolos como os de civilização, democracia, deuses olímpicos, enquanto no extremo oposto figuravam as ideias de barbárie, monarquia, deuses ctónicos. De igual forma, privilegiavam o este sobre o oeste.

Wiles (2003: 40) afirma que, na tragédia antiga, dois oponentes entravam normalmente de lados opostos da orquestra e, na comédia helenística, famílias rivais viviam atrás de duas portas do lado esquerdo e direito num longo plano horizontal. Quando a entrada em cena era executada através da porta central

${ }^{24}$ Em Aristófanes, o termo aparece com a forma de eisodoi. Vide Aristófanes, Nuvens, 326; Aves, 296.

${ }^{25}$ Cf. Pólux, 4.124; Vitrúvio, 5.6.8.

${ }^{26}$ Apud Wiles (1997: 33, 35). Bieber (1961: 75) afirma que o porto estava também associado ao lado direito da audiência.

${ }^{27}$ Os Gregos tendiam a ver o lado direito como auspicioso e o esquerdo como desfavorável. Exemplo disso é o facto de considerarem que os presságios eram positivos se apareciam da direita. Cf. Ésquilo, Agamémnon, 116. 
da skene, os atores ascendiam a esta através de uns degraus que existiam no interior.

Era também por esta porta central que surgia o enkyklema, um dos mecanismos usado mais recorrentemente durante a Época Clássica ${ }^{28}$, pelo menos no que parece dizer respeito às peças de Eurípides ${ }^{29}$. Este artefacto, descrito minuciosamente por Pólux (4.128), consistia numa espécie de máquina rolante ou plataforma movível, feita de madeira, que tinha como principal função dar a conhecer as cenas que supostamente decorreriam no interior da skene, nomeadamente quando essas cenas envolviam mortes. No entanto, era também utilizado em situaçóes mais comedidas, como para permitir que se visualizasse o interior do palácio ou para fazer chegar aos olhos dos espectadores objetos ou personagens que se encontravam no interior. Segundo Bieber (1961: 76), tratava-se de uma plataforma circular ou provavelmente semicircular, podendo também ser quadrangular, que seria manipulada através de um pivot, tal como acontece, hoje, com os modernos cenários movíveis. As portas abriam, quando o cenário era rodado para fora, fechando quando este era retirado para o interior.

Pickard-Cambridge (1946: 119-20) defende a existência de dois tipos de enkyklemata: um concebido de forma a permitir que a plataforma deslizasse horizontalmente até ao exterior, outro em que a plataforma surgia descrevendo um movimento circular ou semicircular. O mesmo autor afirma que o enkyklema frequentemente daria acesso ao chão da orquestra, mas, às vezes, também ao proscénio.

À medida que foi crescendo a importância dos atores, em detrimento do coro, também o relevo concedido à skene foi aumentando, já que, sendo este o espaço privilegiado pelos atores, a ação começou cada vez mais a centrar-se aqui. Desta feita, este edifício deixou de ser temporário para se tornar numa estrutura em pedra, permanente, durante o período da Paz de Nícias, entre 421-415 a.C. ${ }^{30}$. Por esta altura, começaram também

${ }^{28} \mathrm{Na}$ opinião de Taplin (1973: 442-3), o enkyklema só deve ter surgido nos finais do século $\mathrm{V}$ a.C.

${ }^{29}$ Aristófanes parodia com frequência, nas suas comédias, o uso exagerado do ekkyklema por Eurípides. Veja-se a este respeito, por exemplo, Acarnenses, 407, obra que testemunha o recurso a este mecanismo por parte do tragediógrafo.

${ }^{30}$ É comummente aceite que a primeira forma fixa da skene data dos finais da Época Clássica, tendo-se verificado o seu grande desenvolvimento 
a surgir alteraçóes naquela que era a estrutura original da skene, decorrentes das necessidades que as tragédias e comédias representadas na altura demandavam, já que, se muitas são as peças que necessitariam apenas de um edifício e de características pouco elaboradas - como o Íon de Eurípides, cujo único requisito pretendido era o templo de Apolo, em Delfos, ou o Agamémnon de Ésquilo, que pressupunha a existência de um palácio - várias são também as tragédias e as comédias que necessitavam de dois edifícios - como sucede com as Euménides de Ésquilo, que exigia o templo de Apolo em Delfos e o de Atena, em Atenas -, ou até mesmo de três - como as Rás de Aristófanes, onde eram precisos a casa de Héracles, a taberna e o palácio de Plutão. Por essa razão surgiram os paraskenia ${ }^{31}$, situados nas partes laterais da skene e projetados cinco metros em relação a esta, que garantiam as condiçóes exigidas para a exibição de mais do que um edifício e se destinavam também à representaçáo dos atores.

O local reservado a cada um dos intervenientes das composiçóes dramáticas - coro e atores - tem sido alvo de grande controvérsia entre estudiosos. Csapo \& Slater afirmam que, pelo menos a partir de 420 a.C., as fontes literárias e iconográficas $^{32}$ atestam a existência de um palco de madeira, ligeiramente elevado, que ficava encostado à skene e interligado com a orquestra através de degraus - o chamado proscénio.

Parece, no entanto, mais razoável a opinião de Wiles (1997: $15,63)$, que defende que a separação do ator, no palco, do coro, na orquestra, data da Época Helenística, quando a democracia perdeu a verdadeira pertinência política e o teatro passou a estar relacionado com seres humanos individuais, cuja existência tinha começado vincadamente a separar-se da pólis e do divino. Assim sendo, o estudioso acredita que só no século IV a.C., com o relegar dos atores para um plano mais elevado, a

apenas na Época Helenística. Bieber considera, no entanto, que pode ter existido uma estrutura anterior a esta. Para mais pormenores sobre a skene em pedra, vide Bieber (1961: 60).

${ }^{31}$ A origem dos paraskenia é atribuída a Eurípides e Aristófanes, que teriam sentido necessidade da existência de outras possibilidades de entrada em cena. Cf. Bieber (1961: 69).

${ }^{32}$ Csapo \& Slater (1994: 80) baseiam-se, por exemplo, num chous ático de figuras vermelhas de cerca de 420 a.C., patente na coleção Vlastos, Atenas (reprod. Csapo \& Slater 1994: Pl. 4B). Este é, no entanto, o único vaso a fazê-lo. 
performance tenha avançado decididamente para o modelo do proscénio, pelo que, segundo ele, a noção de que, no século $\mathrm{V}$ a.C., os atores representavam sobretudo no palco, enquanto o coro o fazia principalmente na orquestra, mais não é do que uma quimera criada no século XX.

Da mesma opinião partilha Pickard-Cambridge (1946: 71), que defende que a existência de um palco implicaria que náo fosse mais o coro, com o seu ritual de solenidade e a sua função profética, o grande interesse da audiência, mas a arte de representação dos atores; por isso o estudioso entende, tendo em conta o testemunho de Aristóteles (Retórica, 3.1.1403b), que a transferência de interesses da religiáo, metaforizada no coro, para a técnica, identificada com os atores, ocorreu em Atenas ou começou por ocorrer apenas no século IV a.C.

Por outro lado, Bieber (1961: 68) defende que o chamado vaso de Ifigénia, interpretado por Lehmann-Hartleben, é uma prova de que, no séc. IV a.C., os atores não representavam no proscénio, um palco entre os dois paraskenia, mas que se situariam em frente à skene, no chão da orquestra, entre estas duas estruturas.

Um outro nível de representação era a plataforma de madeira que se situava no telhado da skene, o local que ficou conhecido como theologeion, por se destinar, essencialmente, às intervençóes dos deuses ${ }^{33}$. Ao theologeion era possível ascender quer através de degraus que existiam no interior da skene, quer através de um mecanismo, uma espécie de grua que levava o ator até este nível e se designava de mechane. Este engenho que permitia o balouçar dos atores no ar e que, por isso, transmitia a sensação de que as personagens estariam a voar, não só tinha uma funcionalidade prática, porquanto facultava a colocação da personagem no seu espaço de ação, como proporcionava imagens avassaladoras e impressionantes. Várias são as evidências que documentam o seu uso no século V a.C., como o párodo da Paz de Aristófanes (vv. 155-179), obra representada em 421 a.C., ou as Mulheres que celebram as Tesmofórias (1098 sqq.) do mesmo autor, que estreou em 411 a.C., produçôes que Pólux (4.128) refere como comédias nas quais os heróis se serviram deste artefacto. Também na tragédia o seu uso se tornou recorrente como forma de permitir que

${ }^{33}$ Os deuses podiam também movimentar-se sobre os paraskenia, quando estes representavam, por exemplo, templos. 
fossem os deuses, através da fácil introdução facultada pela mechane, a resolverem dificuldades aparentemente insolúveis. E de tal forma este procedimento se tornou comum, que o mesmo foi alvo do sarcasmo por exemplo de Platão (Crátilo, $425 \mathrm{~d}$ ), que afirma que, em situaçóes de dilema, os poetas recorriam, frequentemente, ao theos apo mechanes - ou, para se usar a expressão latina mais consagrada, ao deus ex machina. Também Antífanes (frag. 191. 13-16K) critica o seu uso, afirmando que os poetas trágicos faziam aparecer uma máquina voadora quando não tinham mais nada que dizer; e Aristóteles, na Poética (15.1454b), refere-se ao recurso do theos apo mechanes como um artifício menor para encontrar uma solução, uma vez que o autor se recusava a admitir o irracional no mundo da peça. Eurípides é tido como um utilizador recorrente deste recurso, já que era frequente a intervenção dos deuses no final das suas tragédias.

Da mesma forma que o plano superior dos imortais se fazia sentir no espaço do teatro, através da presença dos deuses em lugares de destaque, e o dos mortais através da movimentação das personagens humanas no plano da orquestra ou do pequeno palco elevado, também o submundo dos mortos podia ser representado. Para isso contribuiu de forma acentuada a criação, na Época Helenística, de uma passagem subterrânea que culminava numa escadaria que dava acesso à orquestra e que permitia apariçóes fantasmagóricas ${ }^{34}$ - as denominadas por Pólux (4.132) como 'escadas de Caronte' (Charoneioi klimakes).

De frente para a skene, quer para a direita quer para a esquerda da orquestra, estavam situados os assentos, encrostados no solo, em várias filas. Os lugares de honra - proedriai ${ }^{35}$ - destinados a sacerdotes e a outras figuras de relevo, como sendo os oficiais da cidade, eram em pedra e posicionavam-se na primeira fila. No centro, figurava o lugar concedido ao sacerdote de Diónisos Eleuthereus. A secção central imediatamente a seguir, na opinião de Bieber (1961: 71), estaria reservada aos convidados de honra, enquanto as cinco secçóes de cada um dos lados destinar-se-iam às dez tribos áticas, que concorriam com dez ditirambos ${ }^{36}$.

${ }^{34}$ Bieber (1961: 78), refere que, às vezes, se viam apenas as cabeças ou o busto das personagens.

${ }^{35}$ Cf. Aristófanes, Cavaleiros, 702-4.

${ }^{36}$ Esta situação foi depreendida pelo facto de ter sido encontrado um bilhete com o nome da tribo de Erecteu. 
As duas secçóes das extremidades de cada um dos lados talvez fossem reservadas aos estrangeiros ${ }^{37}$. As filas superiores eram constituídas por assentos com tábuas móveis - os ainda denominados ikria por Aristófanes (Mulheres que celebram as Tesmofórias, 395) - suportadas por pedras embutidas na terra. Os assentos da primeira fila a seguir à passagem entre as duas primeiras galerias eram também destinados a lugares de honra.

Foi nesta estrutura ainda primitiva do edifício teatral de Diónisos Eleuthereus que o povo grego assistiu ao apogeu do teatro, no que concerne nomeadamente aos grandes poetas. Foi, durante o século $\mathrm{V}$ a.C., que os espectadores puderam vibrar com as obras dos três grandes tragediógrafos mais reconhecidos pela humanidade - Ésquilo, Sófocles e Eurípides - bem como do comediógrafo - Aristófanes.

Ainda no decorrer do século $\mathrm{V}$ a.C., mais precisamente na época de Péricles, em 446-442, um novo edifício foi construído do lado este do teatro - o odeon. Esta estrutura, de forma quadrangular, era utilizada para concertos musicais e durante o proagon ${ }^{38}$, a altura em que os poetas, acompanhados dos atores e do coro, informavam os espectadores do assunto das composiçóes a que iam assistir ${ }^{39}$. A sua configuração permitia uma excelente visibilidade, independentemente do lugar onde estivesse posicionado o espectador.

Provavelmente, na mesma altura em que o odeon foi construído, edificou-se também um corredor de colunas - stoa - que passou a separar fisicamente o local destinado à representação e o destinado ao culto - o santuário; e assim, a pouco e pouco, a religiosidade de que o teatro, inicialmente, estava imbuído foi-se desvanecendo.

Mais tarde, no terceiro quartel do século IV a.C., em 338-326, sob a liderança de Licurgo ${ }^{40}$, foi então construída uma estrutura permanente e em pedra no recinto do teatro, o que levou Croiset (apud Bellessort 1934: 31) a ironizar a esse respeito. Segundo ele, foi quando não tinham já poetas

${ }^{37} \mathrm{O}$ facto de existirem lugares reservados aos estrangeiros é atestado no fragmento $41 \mathrm{~K}$ de uma comédia de Aléxis de Túrios, onde uma mulher se queixa de se ter sentado nos lugares das extremidades, tal como os estrangeiros, quando quis assistir às representaçóes. Cf. Bieber (1961: 71).

${ }^{38}$ Cf. Escólio a Aristófanes, Vespas, 1109.

${ }^{39}$ Vitrúvio (5.9.1) refere ainda uma outra funcionalidade - a de proteger os espectadores da chuva.

${ }^{40}$ Vide Pseudo-Plutarco, Vida dos dez Oradores, 852c. 
trágicos que os Atenienses construíram um teatro em pedra e em mármore, exatamente porque esse foi, sem dúvida, o século em que a grande atração passaram a ser os atores e o seu nível de desempenho em detrimento dos responsáveis pela urdidura da trama - os poetas.

Este teatro, com assentos também eles em pedra, tinha capacidade para cerca de 14 mil espectadores ${ }^{41}$ e continuava a reservar, na fila da frente, lugares de honra para personalidades distintas - as proedriai - mas desta vez em mármore e com a configuração de tronos individuais. De qualquer forma, o auditório foi concebido de maneira verdadeiramente democrática, sendo que os lugares eram igualmente bons em qualquer dos lados, o que levou Wiles (1997: 59) a defender que o teatro mudou progressivamente de um local de absoluto teocentrismo orientado por um templo e um altar para o símbolo de uma sociedade perfeitamente plana e democrática.

Ainda assim e segundo Bellessort (1934: 43) a ótica e a acústica do teatro seriam extremamente defeituosas na zona superior. O autor confirma esta ideia, dando voz à opiniáo de Navarre que afirma que no século IV a.C. os cerca de 6.000 ou 8.000 cidadáos que tomavam lugar no teatro de Diónisos para participarem na assembleia percebiam os oradores porque tomavam assento na zona inferior.

O público entrava no edifício através das parodoi, agora ricamente decoradas com estátuas e dedicatórias, entre a skene e o muro que delimitava o auditório. $\mathrm{Na}$ frente da assistência, localizava-se a orquestra circular ${ }^{42}$ com 1961 metros de diâmetro ${ }^{43}$ e, no centro desta, o altar para as oferendas, que funcionava também como ponto central do movimento do coro. Em redor desta, um enorme canal transportava a água

${ }^{41}$ Pickard-Cambridge (1946: 141) refere que podia admitir cerca de 17 mil espectadores, embora considere mais verosímil um total de 14 mil. Quanto à estimativa de Platão (Banquete, 175e), que aponta para uma audiência de 30 mil espectadores, o mesmo estudioso considera-a absolutamente exagerada.

${ }^{42}$ Camp (2001: 145) defende que a primeira orquestra a ser realmente atestada como circular é a do teatro de Diónisos do século IV a.C. Bieber (1961: 54) acredita que a superfície plana e circular da orquestra grega tem origem na configuração do chão eirado que permaneceu o mesmo, na Grécia, desde a antiguidade.

${ }^{43}$ Cf. Pickard-Cambridge (1946: 146). 
da chuva. Do lado oposto, situava-se a skene permanente, em pedra $^{44}$, que tinha cerca de 20 metros de comprimento.

Entretanto e por causa do papel relevante que cada vez mais os atores passaram a desempenhar, a estrutura inicial do teatro sofreu alteraçóes: a orquestra tornou-se mais pequena e um pequeno palco foi erguido e projetado para a frente do auditório, sendo que os atores passaram, então, a representar neste local - o proscénio ${ }^{45}$.

Segundo Csapo \& Slater (1994: 80-81), esta nova configuração do teatro espalhou-se por todo o mundo grego e, assim, os edifícios teatrais passaram a ter palcos elevados, formados pelo acrescento de um segundo edifício à skene e depois ligando outra plataforma com um piso à parte da frente desta. Os atores transferiram-se para a parte superior do proscénio, designado de logeion por ser o local reservado à fala, e o segundo piso da skene passou a servir de cenário, denominando-se episkenion ${ }^{46}$. Exemplo disso é o teatro de Epidauro, considerado, já na antiguidade, como sendo o mais harmonioso e bonito de todos.

Este edifício apresentava a particularidade de ser um espaço reservado apenas a eventos culturais, sem qualquer carga política e com uma arquitetura que se distanciava da consignada aos edifícios sagrados ${ }^{47}$. Esta estrutura, cuja edificação Pausânias (2.27.5) atribui ao arquiteto Policleto, em 330-320 a.C., era constituída por um auditório simetricamente redondo, que proporcionava uma visão igualmente boa das performances, onde quer que o espectador estivesse posicionado, com 12 secçóes e 13 lances de escadas na primeira galeria e com 22 secçóes

${ }^{44}$ A skene em pedra do teatro de Diónisos Eleuthereus do século IV a.C. é, pela primeira vez, mencionada por Demóstenes (Contra Mídias, 17).

${ }^{45}$ Também por esta altura, mais precisamente no final do século IV a.C., um segundo templo consagrado a Diónisos foi construído. Localizava-se ligeiramente a sul do anterior e albergava uma estátua do deus em ouro e mármore, executada, segundo Pausânias (1.20.3), por Alcâmenes. Segundo Camp (2001: 147), e de acordo com o que restou das suas fundaçóes, este templo consistia numa simples cela com um pórtico de colunas na frente. Pickard-Cambridge (1946: 28) afirma que aparentemente o templo data do último terço do século $\mathrm{V}$ a.C., uma vez que o último registo do trabalho de Alcâmenes é de 403 a.C.

${ }^{46}$ Vide a este propósito a reconstituição do teatro helenístico de E. R. Malyon, apud Csapo \& Slater (1994: fig. 15A).

${ }^{47}$ Wiles (1997: 40) refere que as proporçôes deste edifício são calculadas em cúbitos, uma unidade de medida não reportada aos deuses, mas a uma forma humana idealizada. 
e 23 lances de escadas na segunda galeria. A orquestra, que descrevia um círculo completo, era ladeada por um muro de pedra e cal, e, no centro, a pedra circular, ainda hoje existente, indica provavelmente o local onde haveria um pequeno altar. É também considerado como o primeiro teatro a possuir um palco em pedra.

Começou por ter capacidade para 6.200 espectadores mas, na segunda e última fase da sua construção, em 170-160 a.C., com a introdução de mais 21 filas de lugares, passou a admitir cerca de 12.000 pessoas no recinto.

Segundo Wiles (1997: 43), o teatro de Epidauro é exemplificativo do ideal apolíneo, porquanto era um espaço que refletia a ordem e que possuía uma acústica perfeita para os péanes, a lira de Apolo e as recitaçóes de Homero, ao contrário do que se passava nos teatros dos demos onde a desordem dionisíaca e o irracional seriam mais respeitados do que o conceito de harmonia estética. 
(Página deixada propositadamente em branco) 
3 - Máscaras 
(Página deixada propositadamente em branco) 
Associado aos tempos áureos do teatro grego da Época Clássica ${ }^{1}$ e muito provavelmente como resultado de um espaço de performance ao ar livre está, sem dúvida, o uso da máscara.

A tradição ${ }^{2}$ dá-nos conta de que Téspis, o primeiro tragediógrafo, começou por disfarçar a cara, quando representava, com 'alvaiade' sobre o qual, depois, colocou flores, tendo, só mais tarde, recorrido a máscaras de linho. Depois, sabe-se que Quérilo terá feito algo inespecífico às máscaras e ao vestuário e que Frínico terá introduzido as máscaras femininas. Ésquilo terá sido o primeiro a fazer uso de máscaras coloridas e terrífi$\mathrm{cas}^{3}$, contrastando, aparentemente, com as máscaras brancas (en mone othone $)^{4}$ de Téspis.

Várias têm sido as razóes apontadas para justificar este facto, tais como a necessidade de melhorar a projeçáo vocal ${ }^{5}$, a possibilidade de facultar aos espectadores uma visualização mais eficaz das personagen $s^{6}$ ou a exigência do recurso a um adereço imprescindível num teatro onde não representavam mulheres ${ }^{7}$. Certo é que parece legítimo concordar com Marshall (1999: 190) quando afirma que o uso da máscara resulta mais do facto de o espaço de performance ser apropriado para isso do que da ideia de ser essencial representar mascarado para se transmitir a consciência de um outro eu - tese defendida por Green (1994: 79), que sugere que o motivo subliminar que

${ }^{1}$ Pickard-Cambridge (1953: 177) afirma que é muito incerto o uso da máscara no período mais remoto da tragédia ateniense, embora, nas danças satíricas, os dançarinos surgissem mascarados.

${ }^{2}$ Suda, s.v. Aischylos.

${ }^{3}$ A única evidência arqueológica das características da máscara de ator trágico no tempo de Ésquilo é a que está patente nos fragmentos de uma oinochoe ática de figuras vermelhas encontrada na Ágora de Atenas, de cerca de 470 a.C. (reprod. Pickard-Cambridge 1953: 178-179).

${ }^{4}$ Vide Pickard-Cambridge (1953: 177).

${ }^{5}$ Aulo Gélio (Noites Áticas, 5.7) afirma que as máscaras serviam para fazer ressoar a voz dos atores. No entanto, segundo Pickard-Cambridge (1953: 193), algumas experiências modernas com máscaras manufaturadas, dentro do possível, como nos tempos remotos, deixam sérias dúvidas em relação à probabilidade de as mesmas alguma vez terem permitido a ressonância. De qualquer forma, o autor prossegue, afirmando que certamente nenhum efeito de megafone podia ser produzido por uma máscara fabricada em linho, tal como Téspis afirma ter usado; por isso, esse não seria o material usado originalmente e há dúvidas de que esse efeito pudesse ser conseguido satisfatoriamente sem o uso do metal.

${ }^{6}$ Vide Marshall (1999: 191).

${ }^{7}$ Cf. Seale (1982: 15). 
está na base do uso da máscara, nos tempos mais remotos do teatro, prende-se com um assunto sério: deixar para trás, com o deus no santuário, o outro "eu”, criado em sua honra, para que este não fosse transposto para a sociedade real.

O termo grego prosopon $^{8}$, que significa 'face' ou 'máscara', designava este indispensável adereço, confecionado com fino linho estucado ${ }^{\text {, }}$ que era composto por uma peruca, de cabelo natural, que podia ser curto ou comprido e de várias cores, e por um rosto, que se ajustava à cabeça do ator e que possuía apenas uma abertura para os olhos e outra para a boca, bastante alargadas, para facilitar a visibilidade da audiência ${ }^{10}$ e para, obviamente, permitir as condiçóes necessárias ao desempenho do ator: a visão e a emissão vocal.

Alguns estudiosos, como Pickard-Cambridge (1953: 184), Webster (1965: 5-13) ou Seale (1982: 15), defendem que as primeiras máscaras, usadas durante a Época Clássica ${ }^{11}$, se caracterizavam por ser bastante mais individualizadas do que passaram a ser depois, na Época Helenística, altura em que foram estabelecidos tipos convencionais de máscaras. Outros, cuja visão parece mais credível, como Stanford (1983: 83) ${ }^{12}$, Halliwell (1993: 209) ou Marshall (1999: 189) acreditam que, nos tempos mais remotos do seu uso, a grande particularidade das máscaras era o seu caráter minimalista ${ }^{13}$, sendo que, por

${ }^{8}$ Marshall (1999: 188) defende que o facto de etimologicamente o termo grego significar tanto 'face' como 'máscara' é um exemplo claro de como estes dois conceitos se imiscuíam no pensamento grego.

9 Taylor (1978: 24) afirma que, às vezes, também eram usadas cortiça e madeira.

${ }^{10}$ Existem relatos (Cícero, Sobre o orador, 2.46.193) de que era possível a alguns espectadores visualizarem os olhos e a boca do ator por detrás da máscara. Vide Marshall (1999: 188).

${ }^{11}$ Seale (1982: 15-16) sustenta que, neste período, as máscaras tinham a flexibilidade de ajustarem os mais especializados requisitos, como acontece na Helena de Eurípides (v. 1224), quando esta surge de cabelo cortado.

12 Stanford considera que, nos textos literários, as descrições faciais reduzem-se a traços gerais, já que, ocasionalmente, quando se procede à descrição facial de uma personagem na tragédia, apenas uma ou duas características são mencionadas.

13 Rehm (1992: 41) defende que a audiência se identificaria mais facilmente com o caráter representado pela máscara se esta fosse simples e não muito elaborada, o que faria reduzir a importância dos detalhes faciais e privilegiar as palavras. As faces simples tornar-se-iam, assim, mais personalizadas, pessoais e significativas. A este propósito, McCloud (1993: 36) considera que o facto de a máscara ser aparentemente impessoal 
isso, a manipulação coerente dos tipos básicos existentes seria suficiente para representar, na segunda metade do século $\mathrm{V}$ a.C., tudo o que era necessário às máscaras trágicas.

A falta de expressividade ${ }^{14}$ que as feiçôes da máscara assumiam potenciava, no entanto, significados múltiplos quando o seu uso era conjugado com os elementos que constituem o schema - a postura e os movimentos - e com a voz humana, os quais contribuíam de forma contundente para transmitir à audiência sobretudo emoçóes e estados de espírito vividos pelas personagens que o uso da máscara náo permitia que transparecessem.

De qualquer forma, e apesar deste caráter impessoal das máscaras e da distância que separava atores e espectadores, era sempre possível à audiência identificar duas variáveis nos atores mascarados: o sexo e a idade ${ }^{15}$. Assim, para se representar uma personagem feminina, era usada uma máscara branca; para uma masculina, uma escura. ${ }^{16}$ Relativamente à idade, era possível distinguir três geraçôes diferentes: jovens, adultos e velhos ${ }^{17}$.

Da combinação destas duas variáveis resultaram seis tipos convencionais ${ }^{18}$ de máscaras diferentes, usadas tanto na tragédia como na comédia: a de homem velho (geron), cuja face era escura, a barba e os cabelos brancos, e com a particularidade de, possivelmente, ser calvo; a de homem maduro (aner) que

provocava no espectador a identificação desta consigo mesmo, ao contrário do que acontece quando se visiona uma pintura realista de uma face que é identificável com alguém. Vide também Marshall (1999: 189).

${ }^{14}$ Segundo Taplin (1996: 189), as máscaras trágicas eram, de facto, essencialmente inexpressivas, talvez algo solenes, na medida em que viviam da expressividade inerente aos acontecimentos da peça.

15 Jones (1962: 45) acredita que, para além destas duas características, a audiência conseguia determinar também o estatuto social da personagem. Marshall (1999: 191) contrapõe outra visão, afirmando que esse fator era revelado essencialmente pelo vestuário e pela linguagem corporal.

${ }^{16}$ Segundo MacDowell (1994: 258), esta associação cromática reflete, ou melhor, exagera as condiçóes normais da vida da antiguidade, na qual os homens eram geralmente queimados pelo sol porque passavam muito tempo fora de portas, enquanto as mulheres viviam sobretudo no interior da casa e eram, por isso, mais brancas.

${ }^{17} \mathrm{Na}$ opinião de Marshall (1999: 191), não havia gradaçôes subtis da idade e nunca, nem na Oresteia, se via uma personagem a envelhecer.

${ }^{18}$ Independentemente da falta de consenso quanto à fixaçáo da data por parte dos estudiosos, é unanimemente aceite que, a partir de determinada altura, o uso da máscara passou a reger-se por convençóes que estabeleceram determinados tipos de máscaras. 
se distinguia pelo facto de, para além da face escura, possuir barba e cabelo pretos; a de homem jovem (ephebos) semelhante à de (aner), mas, neste caso, sem barba; a de mulher velha, cuja face era pálida e o cabelo branco (graus); a de mulher madura (gyne), cujas características eram ter a face pálida e o cabelo preto, com um penteado apropriado a uma mulher adulta, e ainda a de mulher jovem (kore), que apresentava uma face também pálida, o cabelo preto mas agora com um penteado infantil ${ }^{19}$. De qualquer forma, e segundo Marshall (1999: 191), esta divisão em género e idade não impedia a audiência de visualizar outros detalhes que não o sexo ou a faixa etária, nem obrigava a que cada máscara fosse uma réplica perfeita de um destes tipos.

A lista que Pólux (4.132 sqq.) sugere, tendo em conta também os critérios de sexo e idade, é todavia mais extensa, mas Marshall (1999: 191) considera que as particularidades definidas por este autor já dos tempos do império romano, para fixar um determinado tipo de máscara, não constituíam diferença significativa teatralmente e eram usadas apenas para distinguir duas personagens que, na mesma peça, surgiam com o mesmo tipo de máscara, embora esse efeito fosse mais notório através do vestuário e da linguagem corporal. Um exemplo disso está bem patente no vaso Phlyax de cerca de 375-350 a.C. (no Louvre $^{20}$ ), onde é possível vislumbrar dois atores em interação: o da esquerda segura um cesto, o outro assume um gesto de argumentação. O tipo de máscara usado pelos dois atores é idêntico, exceto num pequeno pormenor - o da esquerda tem na cabeça uma fita.

Por outro lado, Dearden (1975: 78) defende que havia situaçóes em que o poeta náo sentia que as variaçóes entre duas personagens que contracenassem em palco eram suficientes para sugerir um diferente tipo de máscara, pelo que ambas usavam o mesmo.

Vários exemplos podem ser facilmente atestados, se tivermos em conta as próprias contingências de uma determinada peça. Assim, é esta a situação que parece ocorrer no Rei Édipo, no que concerne às personagens do mensageiro e do pastor, já que, como ambos eram velhos, teriam forçosamente de usar a máscara de geron. Também na Antígona ou na Electra de Sófocles, o facto

${ }^{19}$ Vide Marshall (1999: 191).

${ }^{20}$ Vide Bieber (1961: 141), fig. 515. 
de existir um par de irmãs em cena leva-nos a crer que ambas tivessem que ser representadas por uma máscara do tipo kore. Igualmente na comédia, e particularmente em Aristófanes, se terá verificado esta situação, porquanto parece difícil identificar qualquer tipo de diferença entre os dois escravos - Sósia e Xântias - que intervêm nas Vespas.

Por outro lado, dificilmente um mesmo ator usaria o mesmo tipo de máscara para representar personagens diferentes, de forma a evitar a confusão da audiência. Assim, segundo Marshall (1999: 196), se o mesmo ator ${ }^{21}$ representasse, nas Bacantes de Eurípides, Cadmo e os dois mensageiros, então, como Cadmo é um velho, um dos mensageiros seria jovem e o outro um homem maduro. Esta seria também a razão, no entender do estudioso, para que pares do mesmo sexo, nas peças do século $\mathrm{V}$, fossem geralmente de geraçóes diferentes.

Por vezes, conseguiam-se efeitos especiais, introduzindo-se pequenas variaçóes no estabelecido, como sendo a alteração da cor da face, o que proporcionava outras simbologias. Assim, pelo simples facto de uma personagem masculina ser representada com uma máscara pálida, criava-se o efeito desejado ou para se apresentar uma figura fantasmagórica - por exemplo, Dario nos Persas de Ésquilo, - ou para se transmitir à audiência a sugestáo de que determinada personagem tinha traços efeminados ${ }^{22}$ - Ágaton em As mulheres que celebram as Tesmofórias de Aristófanes ou os estudantes nas Nuvens do mesmo dramaturgo - ou ainda para demonstrar o estado moribundo de uma dada personagem - Orestes no início das Euménides de Ésquilo.

Também a cor e o estilo do penteado das perucas podiam ser alterados de forma a criar efeitos especiais. Por exemplo, na Ifigénia em Áulide de Eurípides, diferentes cores de cabelo podem ter sido usadas para distinguir Menelau e Agamémnon ${ }^{23}$, ou

${ }^{21}$ Pelo facto de em cada peça poderem geralmente atuar apenas três atores, estes tinham que se desdobrar de forma a poderem representar todas as personagens.

22 É o que defende MacDowell (1995: 258), por exemplo, no caso concreto das Nuvens. Sommerstein (1996: 47) tem sugerido a provável utilização de máscaras deste tipo por parte de Ésquilo para retratar a figura de Egisto na Oresteia, já que frequentemente o mesmo é apelidado de mulher pelos inimigos.

${ }^{23}$ Marshall (1999: 195) acredita que é natural que, na Ifigénia em Aulide, Eurípides seguisse as orientações de Homero e apresentasse Menelau 
então facilmente se poderia sugerir que uma dada personagem estava na condição de cativa se ela surgisse com uma máscara com o cabelo rapado ${ }^{24}$.

De qualquer forma, Marshall também admite que situaçóes especiais podiam ser representadas por máscaras também elas especiais, embora isso nunca ocorresse sem um aviso prévio do poeta, inserido no próprio texto interpretado pelos atores. Um caso que reflete de forma perentória esta situação é aquele que se depreende ter acontecido aquando da representação da Oresteia, nomeadamente, no que concerne às Erínias. Segundo a tradição ${ }^{25}$, a aparição destes seres terá causado enorme temeridade entre a audiência, tal seria o impacto causado pela sua caracterização nos espectadores. No entanto, Stanford (1983: 79) defende que esta reação terá sido causada, primeiramente, pela força das palavras usadas por Orestes, no momento em que as descreve, antes ainda da própria entrada em cena.

Também para representar a cegueira eram usadas máscaras especiais ${ }^{26}$. Marshall (1999: 192, n. 41) acredita que nas tragédias mais tardias, nomeadamente no caso concreto da tragédia perdida Tâmiras de Sófocles, a máscara usada para traduzir a cegueira apresentasse características peculiares que, mais tarde, se revelariam impraticáveis, porquanto o mesmo autor defende que a máscara estaria dividida a meio, representando uma das partes a personagem enquanto dotada de visão e a outra quando já cega ${ }^{27}$; e isto, obviamente, limitaria os movimentos

com um cabelo mais louro do que Agamémnon, embora ambos usassem máscaras de aner.

${ }^{24}$ Marshall (1999: 195) defende que é o que parece ter acontecido com Hécuba, Cassandra, Andrómaca e o coro de servas nas Troianas de Eurípides. O cabelo rapado servia também para representar uma personagem enlutada. Vide Eurípides, Orestes, 458. O próprio cabelo do ator podia ser rapado durante a performance, porquanto a maioria das peças era representada apenas uma vez e, ainda que houvesse alguma reposiçáo, num outro festival, facilmente se poderia colar o cabelo para ser novamente rapado.

${ }^{25}$ Vida de Ésquilo, p. 4; Pólux, 4.110; Pausânias, 1.28.6.

${ }^{26}$ Walton (1991: 158) duvida que se usassem máscaras de cego.

${ }^{27}$ Lessing acredita que a história de que Tâmiras tinha um olho azul e outro preto surgiu pelo facto de a máscara usada pelo ator ostentar um olho azul, que ele apresentava à audiência antes da cegueira, e outro preto, visível só depois disso. Apud Marshall (1999: 192). 
do ator, uma vez que a audiência estava disposta em três locais diferentes da área de performance.

De qualquer forma, existem outras peças onde a necessidade de uma segunda máscara parece provável quer para representar esta alteração nas características de uma personagem ${ }^{28}$, como tudo indica ter acontecido no Rei Édipo de Sófocles, quer outras. Assim, por exemplo, presume-se que, na Hécuba de Eurípides, o tragediógrafo tenha recorrido a uma segunda máscara para demonstrar as faces arranhadas da heroína de manhã.

Já para se representar a morte, no geral, não haveria necessidade de se recorrer a uma segunda máscara, porquanto as mortes ocorriam, na generalidade, longe dos olhares dos espectadores e, ainda que se pretendesse exibir a personagem morta, através do recurso ao enkyklema, o ator poderia surgir sob a forma de um cadáver ou valendo-se do seu próprio corpo ou servindo-se de um boneco que apareceria munido com a mesma máscara usada pelo ator, quando a personagem por si desempenhada estava ainda viva. Marshall (1999: 193) acredita, inclusivamente, que o uso de uma segunda máscara para demonstrar a morte só serviria para causar confusão na audiência. Outra forma de representar a morte, se esta se concretizasse através da decapitaçáo, como acontece com Penteu nas Bacantes de Eurípides, poderia resultar do simples facto de se exibir a máscara usada pela personagem, que funcionaria, assim, como se fosse a sua própria cabeça cortada.

No que diz respeito às divindades, as máscaras utilizadas não parecem ter diferido das usadas pelos mortais ${ }^{29}$, até porque, geralmente, a aparição do deus fazia-se ex machina e o mesmo assumia a sua aparência antropomórfica.

De qualquer forma, outras máscaras especiais - ekskeua prosopa - usadas na tragédia são descritas por Pólux, tais como a de Actéon a usar cornos, a do cego Fineu, a de Tâmiras, com

${ }^{28}$ Seale (1982: 16) defende que, relativamente ao Rei Édipo, era provável que houvesse uma segunda máscara, manchada de sangue, para ser usada depois da cegueira auto-infligida. Taplin (1978: 89) considera que Édipo terá feito uso de uma segunda máscara com cavidades escuras nos olhos, a partir das quais correria um fluxo de sangue.

${ }^{29}$ Esta é a visão defendida por Dearden (1976: 125), que se baseia no facto de, por um lado, não figurar nenhum dos deuses na lista especial de máscaras e, por outro, de as evidências dos vasos e terracotas demonstrarem que, quando os deuses apareciam em palco, usavam máscaras comuns às dos mortais. 
um olho azul e outro preto, a de Argos, com muitos olhos, a de Evipe quando se transforma em cavalo, a de Tiro, ferida pela mãe, Sidero, a de Aquiles com o cabelo rapado em sinal de luto por Pátroclo, a de Amimone, a de Príamo, as máscaras de Titã, Rio, Tritão, Fúria, Morte e ainda as de personificações como Raiva (Lyssa), Paixão (Oistros), Insolência (Hybris), Engano (Apate), Embriaguez (Methe), Preguiça (Oknos), Inveja (Phthonos), Musas, Ninfas, Horas, Plêiades, etc. No entanto e segundo Pickard-Cambridge (1953: 193), infelizmente, Pólux não apresenta nenhuma indicação de datas e esta lista - baseada provavelmente nos tipos fixados de um período pós-clássico - não pode fornecer muita informação acerca dos períodos mais remotos, nos quais deve ter havido menos exagero e mais liberdade.

Também na comédia, esporadicamente, eram concebidos outros tipos de máscaras para criar efeitos especiais ${ }^{30}$. Um exemplo desta situação é o que Marshall (1999: 195) defende ter ocorrido na versão original das Nuvens, onde acredita que Aristófanes tenha colocado em cena dois galos a discutirem para representar os Raciocínios.

Um outro tipo de máscaras especiais, típicas da comédia, eram as chamadas máscaras-retrato ${ }^{31}$. Através destas, cuja existência é atestada pela tradição ${ }^{32}$, pretendia-se a representação de uma determinada figura pública, recorrendo-se a traços fisionómicos específicos. Pickard-Cambridge (1953: 197) acredita que o seu uso ter-se-á deixado de verificar no final do século $\mathrm{V}$ a.C., altura em que, segundo Platónio (Sobre as diferenças entre comédias, 13), na Comédia de Transição e na Comédia Nova, se começaram a evitar as semelhanças fisionómicas e se

${ }^{30}$ Pickard-Cambridge (1953: 196-197) defende que é evidente que na Comédia Antiga se gozava de plena liberdade na produção de máscaras, de forma a corresponder às exigências de determinados caracteres.

31 Pickard-Cambridge (1953: 197) considera que as representaçóes burlescas de pessoas vivas podiam ser reconhecidas como retratos, com algum grau de caricatura, de figuras públicas. No entanto, Marshall (1999: 194) defende que não há nenhuma evidência certa de que alguma vez este tipo de máscaras tivesse sido usado.

${ }^{32} \mathrm{O}$ exemplo mais famoso prende-se com as Nuvens de Aristófanes, já que, segundo a tradição, a máscara usada por Sócrates era de tal forma associada ao filósofo, que o mesmo terá omitido a sua identidade, quando os estrangeiros que, como ele, em 423 a.C. assistiam à representação da comédia, perguntaram quem era Sócrates. Vide Eliano, História Vária, 2.13. 
passou a recorrer a máscaras com feições tão exageradas que era impossível assemelharem-se a qualquer ser humano real.

Em relação a outras máscaras típicas de um determinado tipo de personagens cómicas, como a da velha enrugada com falhas nos dentes ou a do velho com um bastão ${ }^{33}$, PickardCambridge (1953: 196) defende que talvez tivessem tido uma origem dórica, porquanto foram encontradas, em Esparta, máscaras votivas que correspondem de muito perto às descriçóes de caracteres de Aristófanes. No entanto e segundo o mesmo estudioso, são poucas ou até mesmo nenhumas as representaçóes de cenas ou de personagens da comédia, nos vasos áticos dos séculos V ou IV a.C., pelo que se torna difícil extrair quaisquer conclusóes definitivas.

Quanto à sátira, Pickard-Cambridge (1953: 188), baseado num passo obscuro de Pólux (4.142), no final da sua listagem sobre máscaras trágicas, acredita que, à exceção das máscaras destinadas aos sátiros e ao Sileno, todas as outras em nada pareciam diferir das usadas na tragédia ${ }^{34}$. A máscara de Sileno, considerada a mais antiga versão de máscaras usadas pelos coros satíricos, caracterizava-se por possuir nariz achatado, lábios grossos, olhos empolados, em suma, por representar um semblante feio e devasso. É esta a posiçáo defendida por Marshall (1999: 194), que acredita que Aristófanes se tenha servido de uma máscara com estas características para representar Sócrates, nas Nuvens ${ }^{35}$.

Relativamente aos elementos dos outros tipos de coros, e no que concerne à tragédia, tudo parece convergir para a crença de que as máscaras por si usadas em nada se distinguiam das estabelecidas para os atores trágicos ${ }^{36}$. É esta a opinião de

33 Pólux descreve outras máscaras cómicas. Vide Pickard-Cambrigde (1953: 203-210).

${ }^{34} \mathrm{Um}$ exemplo típico das máscaras utilizadas pelos sátiros é o que figura no vaso Prónomo, um krater de volutas ático de figuras vermelhas, de cerca de 400 a.C., que se encontra no museu de Nápoles (reprod. Pickard-Cambridge 1953: fig. 28).

35 Também Dover (1967: 26) acredita que, neste caso concreto, Aristófanes se tenha servido de uma máscara de Sileno para representar a figura de Sócrates, pelo que esta seria outra alternativa para se criarem efeitos especiais, ou seja, através da importação de uma máscara típica de um dos três géneros para um outro contexto.

36 Exceção já referida é a que se verifica no caso das Erínias, nas Euménides de Ésquilo. 
Marshall, que acredita que, mesmo nos passos em que são sugeridas máscaras especiais, não haveria necessidade de ir além do padronizado iconograficamente.

Parece também provável que os membros do coro na tragédia usassem todos máscaras iguais. Exemplo disso é o vaso Baseleia $^{37}$, de cerca de 500-490 a.C., onde figuram três pares de jovens que se movem, com gestos idênticos, até um altar decorado com ramos e faixas, enquanto cantam. Segundo Csapo \& Slater (1994: 53), esta figuração revela a uniformidade das máscaras usadas pelo semicoro, porquanto o artista representou-o com caras semelhantes, as bocas abertas e os queixos salientes e alinhados. Também numa pelike ática de figuras vermelhas, conservada no Museum of Fine Arts de Boston (reprod. Pickard-Cambridge 1953: fig. 39), é possível verificar a semelhança das máscaras femininas usadas pelos dois coreutas representados.

Já na comédia, não se verificava esta uniformidade. Pelo menos é o que se depreende das Aves de Aristófanes, onde, ao que parece, todo o tipo de aves estaria representado, porquanto, no párodo (vv. 296-306), Aristófanes identifica cada um dos 24 coreutas de forma diferente. A contrariar esta diversidade parece estar o kalyx-krater ático de figuras vermelhas da coleção do J. Paul Getty Museum (reprod. Csapo \& Slater 1994: Pl. 5), tido como uma possível ilustração contemporânea daquela comédia de Aristófanes e onde as personagens representadas parecem ser muito idênticas.

Por outro lado e, segundo Pickard-Cambridge (1953: 195), quando o coro não era estritamente animal mas também não era humano, como acontece nas Nuvens de Aristófanes, eram inventadas máscaras grotescas para satisfazer as fantasias do poeta.

No caso da representação de figuras humanas, não se sabe de que forma estavam mascarados os elementos do coro que as protagonizavam, mas os velhos e as velhas eram representados, sem dúvida, de forma grotesca.

Da mesma forma e segundo Pickard-Cambridge (1953: 195), não é possível saber como os poetas representavam personificaçóes coletivas, como as de Ploutoi de Cratino ou Poleis e Demoi de Êpolis. Apenas se pode assumir que a imaginação

37 Krater de colunas ático de figuras vermelhas, que se encontra no museu de arte antiga de Basileia (reprod. Csapo \& Slater 1994: Pl. 1A). 
do poeta não estava de forma alguma limitada por convençôes estereotipadas e que, tal como parece ter acontecido nas Aves de Aristófanes, os membros do coro não tinham de estar todos caracterizados de forma igual.

Pelo exposto, é pois possível constatar que nos primeiros tempos da Época Clássica, apesar de haver uma certa liberdade na confeção das máscaras, a inclinação geral era para evitar o exagero, situação que deixou de se verificar na Época Helenística, quando a contenção deu lugar à exorbitância e, por isso, a tendência foi para exagerar na expressividade da máscara, quer através da representação excessiva da abertura da boca quer da introdução do onkos, uma elevação da máscara acima da testa ${ }^{38}$. Bulle (apud Pickard-Cambridge 1953: 193-194) defende que esta particularidade das máscaras foi condicionada pela introdução, no edifício teatral, do proscénio, mas PickardCambridge (1953: 194) considera que as mais antigas máscaras com um elevado onkos parecem datar de 300 a.C. e, portanto, afigura-se improvável que tenham decorrido da alteração do espaço de ação, a qual se verificou por volta de 330 a.C. Um exemplo bem nítido do que era o onkos é visível na pintura de Herculano ${ }^{39}$, datada provavelmente de finais do século IV ou princípios do III a.C., e na qual é possível vislumbrar uma máscara colocada num recetáculo sobre um pilar, que ostenta um elevado onkos, um longo cabelo de ambos os lados, a boca amplamente aberta e os olhos arregalados.

A respeito desta evoluçáo, Pickard-Cambridge (1953: 185) refere que o naturalismo das máscaras mais antigas desapareceu e a tragicidade tornou-se exagerada. No entanto, existem outras fontes que atestam que nem sempre o onkos era concebido de forma tão excessiva, como é possível verificar numa estátua, existente nos Museus do Vaticano e datada da segunda metade do século IV a.C., que segura numa das mãos uma máscara

${ }^{38}$ Esta datação cronológica é corroborada pelas fontes iconográficas anteriores a este período, cujas máscaras representadas não revelam a existência destas características. Exemplo disso é o denominado vaso Prónomo, atrás referido, datado de cerca de 400 a.C. (cf. supra cap. 3, n. 34).

${ }^{39}$ Representação votiva dedicada a um ator trágico vitorioso. 
deste tipo, com um onkos, sem dúvida, muito mais contido do que o da máscara visível na pintura de Herculano ${ }^{40}$.

De qualquer forma, torna-se evidente que, tal como aconteceu no que diz respeito ao edifício teatral, também no uso da máscara é possível constatar a existência de um processo evolutivo e, assim, ainda que possa haver alguma disparidade de opinióes em termos cronológicos e no que concerne ao maior ou menor grau de individualização das primeiras máscaras, certo é que com o passar dos séculos e à medida que se foi entrando na Época Helenística e se foram detetando também alteraçôes nas expectativas e no gosto dos espectadores, agora mais vocacionados para performances vincadamente mais espetaculares, houve uma tendência para a excessividade, tendo-se nitidamente acentuado o grau de exagero com que as máscaras passaram a ser exibidas. Para isso terá contribuído também a importância crescente que passou a ser atribuída aos atores e consequentemente a própria evolução do edifício teatral, que, ao conferir um local de destaque a estes últimos elementos através da criação do proscénio, de uma forma mais ou menos evidente, terá também provocado alteraçóes na própria conceção das máscaras.

${ }^{40}$ Wiles (1991: 179) defende que, por esta altura, ter-se-á verificado também um desejo irresistível de representar fatores fisionómicos. 
4 - Vestuário 
(Página deixada propositadamente em branco) 
A par da máscara e dos gestos, o vestuário desempenhava um importante papel (se não mesmo o mais importante) na determinação pelo público do estatuto social representado pelas personagens, cujas características podiam facilmente ser expressas através das cores, texturas e designs ${ }^{1}$. No entanto, é impossível determinar com exatidáo os figurinos usados pelos atores, nos primeiros tempos do teatro. Pondo de parte as fontes literárias, a iconografia de que dispomos náo pode ser tida como um testemunho irrefutável do vestuário teatral usado durante o século V a.C. ${ }^{2}$, porquanto, na sua grande maioria, ela pertence a uma época posterior e, mesmo quando coincidente, não pode ser descurada a ideia de que muitas das figuraçôes eram o resultado do ideal que o artista tinha do mito que estava na base de uma determinada peça e, como tal, essas figuraçóes não podem ser vistas como reprodução explícita e fiel de uma representaçáo concreta. De qualquer forma, da sua análise, parece poder concluir-se que os figurinos trágicos se baseavam no manto com que Diónisos é frequentemente representado ${ }^{3}$.

Esta é a opinião defendida por Taylor (1978: 22), que acredita que o vestuário típico da tragédia era constituído por uma túnica inteiriça até ao chão, coberta por um pequeno manto que ficava acima dos joelhos. As mangas ${ }^{4}$ eram compridas, decoradas ricamente e de variadas formas e, conforme se

${ }^{1}$ Segundo Brooke $(1962: 1,10)$, a eliminação de detalhes desnecessários e um certo exagero em formas mais expressivas era a chave da consecução artística. Assim, a essência do vestuário trágico residia na magnificência das roupagens usadas, no valor a elas associado e no efeito de ondulação que permitiam obter.

${ }^{2}$ Existem, no entanto, três vasos, dois datados da última década do séc.V a.C., um do início do século IV a.C. (o assim designado krater de Andrómeda, um krater ático de figuras vermelhas conservado em Cápua [reprod. Pickard-Cambridge 1953: fig. 164]; o krater de Prónomo [vide supra cap. 3, n. 34] e o fragmento de um krater do estilo Gnatia de Tarento, conservado no Museu Wagner de Würzburg [reprod. Pickard-Cambridge 1953: fig. 34]) que, no entender de Pickard-Cambridge (1953: 217) devem ser tidos em conta, uma vez que representam, de forma muito similar, aquele que seria o típico vestuário trágico do século $\mathrm{V}$ a.C.

${ }^{3}$ Exemplo disso é uma ânfora ática de figuras negras, de cerca de 500 a.C. (reprod. Pickard-Cambridge 1953: fig. 162).

${ }^{4} \mathrm{O}$ uso recorrente das mangas prende-se com um pormenor técnico - evitar a exposição de braços nitidamente masculinos em personagens femininas. $\mathrm{O}$ mesmo se passava relativamente à exibição das pernas e do 
pode ler em Pickard-Cambridge (1953: 212), ora surgiam na túnica (syrma), ora na peça que lhe ficava sobreposta, que se denominava assim de cheiridotos chiton. O manto - himation - podia aparecer disposto de muitas maneiras 5 e era usado indiscriminadamente por homens e por mulheres. Em todas as peças, o recurso a bordados com motivos variados ${ }^{6}$, como espirais ou esfinges, proporcionava padróes múltiplos e uma diversidade de efeitos considerável ${ }^{7}$. Existem, no entanto, duas figuraçóes do século IV a.C. ${ }^{8}$ que representam atores (pelo menos, com toda a certeza, no krater de Tarento) vestidos com túnicas pouco decoradas. Pickard-Cambridge (1953: 225) coloca duas hipóteses para justificar esta situação: ou estas figuraçóes revelam que era possível alguma liberdade na forma de vestir os atores trágicos, sem que houvesse um nível acentuado de decoração nos seus trajes, ou demonstram que, antes do final do século IV a. C., esta última conceção da forma de vestir caiu em desuso.

Por outro lado, Brooke (1962: 64-65)9 defende que o vestuário trágico se baseava no peplos e não no chiton, de origem dórica ou iónica, usado na vida civil, já que, da análise dos vasos, parece evidente o uso de um determinado tipo de

pescoço e daí o uso, muito frequente, de túnicas até ao chão e de colarinhos fechados.

5 Segundo Brooke (1962: 27-8), existem, literalmente, dúzias de formas diferentes de dispor o himation.

${ }^{6}$ Brooke (1962: 13) estabelece uma analogia entre os motivos decorativos usados no vestuário e na arquitetura, ao afirmar que as figuras e as linhas corridas dos padróes eram semelhantes tanto nas roupas como nos edifícios arquitetónicos. Muitos dos ornamentos tinham como único propósito a mera decoração e podiam surgir na forma de quadrados, discos, em formatos ovais ou em forma de flores.

7 Seale (1982: 15) defende que o vestuário, no século V a.C., era colorido e as túnicas e os mantos compridos e flutuantes.

${ }^{8}$ As figuraçóes em questão correspondem a uma escultura em relevo oriunda do Pireu e atualmente conservada no Museu Arqueológico de Atenas (reprod. Pickard-Cambridge 1953: fig. 26) e ao já referido krater de Tarento (vide supra cap. 4, n. 2). Relativamente a este último vaso, Bulle classifica o ator como estando a representar um rei no exílio, enquanto Rumpf considera que se trata do figurino típico do ator trágico no período alexandrino. Apud Pickard-Cambridge (1953: 226).

${ }^{9}$ Segundo o estudioso, o chiton fixava-se nos ombros por intermédio de alfinetes e por isso o peplos permitia mais facilmente que a peça ficasse corretamente colocada, sem restringir os movimentos e evitando que a mesma se deslocasse da sua posição. 
túnica presa aos ombros não por intermédio de alfinetes, mas de um colarinho quadrangular, sendo que a peça caía depois ao longo do corpo e ficava ajustada à cintura através de um cinto largo, forte e ornamentado ${ }^{10}$. Há, no entanto, situaçôes em que se depreende o uso dos alfinetes, o que poderá indicar a influência do chiton no vestuário teatral. Exemplo disso é o que deve ter acontecido na exibição da Hécuba de Eurípides, onde Marshall (2001: 127) acredita que o didaskalos se tenha socorrido de peplos com alfinetes ${ }^{11}$ para vestir as mulheres, já que este tipo de vestuário serviria assim três propósitos: por um lado, viabilizar a utilização dos alfinetes, não apenas por uma questão estética, mas como arma usada para provocar a cegueira de Polimestor $^{12}$; depois, transmitir à audiência a vulnerabilidade sexual a que as mulheres estavam sujeitas ${ }^{13}$; por último, aproximá-las mais da forma tradicional de vestir grega, já que estas mulheres não só tinham sofrido a influência

${ }^{10}$ De qualquer forma, no entender do estudioso (1962: 66-7), o uso do peplos como vestuário típico da tragédia não invalidava o facto de se poder usar outro tipo de túnica ou de chiton, embora o peplos servisse na perfeição os interesses teatrais, porquanto permitia que os atores mudassem de roupa rapidamente e, numa altura em que apenas três atores desempenhavam o papel de todas as personagens presentes numa tragédia, a celeridade com que trocavam de figurino era, sem dúvida, uma condiçáo sine qua non para a escolha de um determinado tipo de vestuário.

${ }^{11}$ Esta forma de fixar a peça com o recurso a alfinetes, a broches ou fíbulas, podia ocorrer quer no chiton, quer no himation.

12 Vide Eurípides, Hécuba, 1053. Este adereço foi também utilizado para provocar a cegueira de Édipo na peça homónima de Sófocles (Édipo arranca os alfinetes que prendiam o vestido de Jocasta e crava-os nas órbitas).

${ }^{13}$ A carga erótica associada a este figurino resultava do facto de o peplos ser aberto de um dos lados para expor mais o corpo. Na Andrómaca, 598, Eurípides torna essa conotação sexual explícita através das palavras proferidas por Peleu, na descrição do traje único usado pelas donzelas espartanas, que era aberto dos lados de forma a mostrar as suas coxas, quando estas se moviam. Obviamente que, neste caso concreto, é maior a força das palavras do que a concretização prática desta situação, porquanto qualquer personagem feminina era desempenhada por um homem e, por isso, a carga erótica pretendida dificilmente poderia ser representada. Uma outra consequência resultante do uso deste tipo de vestuário era que, ao remover os alfinetes, o peplos caía, expondo o peito, tal como se depreende ter acontecido nas Traquinias, 923-26, de Sófocles, embora, mais uma vez, houvesse alguma dificuldade prática na representação desta situação. 
de Helena, uma espartana, como também estavam agora na condição de cativas dos vitoriosos gregos.

Por outro lado e quanto às personagens gregas presentes na tragédia, o mesmo estudioso (2001: 136) acredita que é possível que Eurípides as tenha colocado em cena com um tipo de vestuário que refletisse o interesse contemporâneo dos atenienses pelo estilo persa. Sobre a forma de vestir dos Persas, existem fontes literárias e iconográficas que nos permitem ter uma visão aproximada da realidade. Nos Persas de Ésquilo, por exemplo, parece provável que a rainha ${ }^{14}$ e o fantasma de Dario usassem um vestuário exuberante, como forma de transmitir a hybris cometida. Nesse sentido Hall (1989: 70) acredita que esta forma de vestir funcionasse como uma metáfora da saúde do império que há de ser destruído, tal como as roupas de Xerxes rasgadas e conspurcadas. Da mesma opiniáo partilha Pickard-Cambridge (1953: 224), que acredita que o coro dos Persas deve ter sido caracterizado à maneira dos antigos nobres persas, ou seja, de uma forma luxuosa e a usarem calças ${ }^{15}$, peça de vestuário, aliás, regularmente associada a este povo e aos orientais em geral na arte grega.

Outros exemplos de figurinos usados pelo coro podem ser facilmente encontrados, porquanto este estava sempre vestido de acordo com a sua nacionalidade e com o seu estatuto ${ }^{16}$. Assim, as Fenícias de Eurípides terão sido caracterizadas com um vestuário oriental (ou à maneira asiática ou à maneira egípcia), e as Suplicantes de Ésquilo segundo um estilo bárbaro, com roupagens seguras por um cinto, cujo tecido seria riquíssimo e majestoso ${ }^{17}$. Já nas Suplicantes de Eurípides, o tragediógrafo

${ }^{14} \mathrm{O}$ coro (vv. 150-8) compara a sua aparência à luz que erradia dos olhos dos deuses..

${ }^{15}$ No krater de Andrómeda oriundo de Cápua, geralmente datado do final do século $\mathrm{V}$ a.C., é possível vislumbrar um etíope a usar calças (vide supra cap. 4, n. 2).

16 Uma das particularidades da forma de caracterizar os elementos do coro, nas peças do século V a.C., era a existência de uma certa uniformidade nos figurinos, com vista a acentuar a sua dimensão coletiva, diluindo assim os elementos que apontavam no sentido da individualidade.

17 Segundo Bellessort (1934: 40), quando, nas Suplicantes 234-6, o coro das Danaides chegou do Egito, vários espectadores ter-se-ão sentido tentados a gritar como o rei dos Argivos: "De onde chega esta multidão, de aspeto tão pouco grego, faustosamente equipada com vestes e bárbaras cintas no cabelo, a quem dirijo a palavra?”. Tradução de Carlos A. Martins de Jesus (no prelo). 
terá optado por representá-las de luto (v. 97), com vestes negras $^{18}$, portanto. De luto, estariam também caracterizadas as Coéforas e, nas Euménides, os elementos do coro terão surgido com a pele negra, sem que, contudo, se saiba o que trariam vestido $^{19}$. Essa informação existe somente em relação à parte final da tragédia, altura em que é feita referência aos mantos escarlates (v. 1028) que, entretanto, terão passado a envergar e que refletiriam a mudança, entrementes operada. Brooke (1962: 101) defende que Ésquilo as deve ter caracterizado de uma forma horrífica e repulsiva, já que, na tragédia, elas são descritas como Harpias, sem asas, negras, inteiramente repugnantes e com serpentes nas suas vestes (vv. 48-56).

Há, no entanto, visões muito diferentes das Fúrias nas representaçóes dos vasos, sendo que, muitas vezes, figuram ora como divindades positivas ora negativas, de pele branca ou escura, rodeadas ou não de serpentes. Exemplo dessas visóes antagónicas é bem evidente na comparação do krater de sino de figuras vermelhas de Armento, dos inícios do séc. IV, conservado no Museu do Louvre (reprod. Pickard-Cambridge 1953: fig. 175) e de um vaso Pestense com a mesma configuração, de meados desse século, atribuído ao Pintor de Píton e patente no British Museum (reprod. Pickard-Cambridge 1953: fig. 176). Relativamente às Bacantes, é seguro que as seguidoras de Diónisos tivessem usado peles de cervo $^{20}$ e, segundo Brooke (1962: 102-3), a sua aparição em cena terá causado tanto ou mais impacto do que a visualização das Fúrias, até porque, para além das peles, estas mulheres transportariam serpentes e heras nos cabelos e tirsos nas mãos ${ }^{21}$. Além disso, existiria também uma grande variedade de vestimentas, porquanto entre as Bacantes estavam mulheres novas e velhas, autóctones

18 Taylor (1978: 22) acredita que esta era a cor usada também para representar personagens pobres ou melancólicas.

${ }^{19}$ Esta forma de apresentar os elementos do coro estaria em consonância com o facto de as Fúrias serem divindades primitivas, provavelmente com uma caracterização claramente menos antropomórfica do que Apolo e Atena.

${ }^{20}$ Quanto a Cadmo e a Tirésias, Marshal (1999: 196) defende que terão usado um vestuário báquico semelhante, ao passo que Diónisos e Penteu estariam caracterizados com um trajo de traços femininos.

${ }^{21}$ Vide Eurípides, Bacantes, 105 sqq., 695 sqq. 
e estrangeiras, o que, neste último caso, pressuporia o uso de um vestuário mais exótico.

Existem, ainda, exemplos de coros de marinheiros ${ }^{22}$, de guerreiros $^{23}$ e de anciãos ${ }^{24}$.

Relativamente às personagens individuais, o vestuário por elas usado podia também, muitas vezes, ser representativo do respetivo estado de espírito e/ ou condição. Assim, era frequente a exibição do luto através de vestes negras, como acontece, por exemplo, com Electra, nas Coéforas, ou a revelação da condição de cativa de uma personagem pelo facto de a mesma surgir vestida com trapos ${ }^{25}$. Também a desgraça de Filoctetes ${ }^{26}$ e de Édipo $^{27}$, a condição de náufrago de Menelau ${ }^{28}$ e a loucura de Orestes $^{29}$ podem ter sido expressas e reforçadas, no entender de Pickard-Cambridge (1953: 225), pelas roupas usadas.

Por tudo isto, pode concluir-se que quer os elementos do coro quer os atores apareciam não só vestidos de acordo com a natureza das personagens que representavam como também refletiam o estilo próprio de cada tragediógrafo.

Assim, embora seja duvidosa a atribuição que a tradição outorga a Ésquilo da invenção do vestuário trágico ${ }^{30}$, é possível estabelecer, através do recurso às fontes literárias, nome-

${ }^{22}$ Ajax e Filoctetes de Sófocles. Embora não se saiba como seria o vestuário típico dos marinheiros, Brooke (1962: 102) considera que o mesmo se caracterizaria por ser prático e simples e que consistiria numa túnica curta, presa por um cinto.

${ }^{23}$ Vide Eurípides, Reso. O vaso de Basileia (vide supra cap. 3, n. 37) sugere um coro de guerreiros que, em vez de usarem elmos, usam diademas, o que constitui uma prova de que as figuras representadas estáo em contexto teatral. Csapo \& Slater (1994: 57) afirmam que uma das versóes mais correntes é a de que o vaso retrata os Persas de Esquilo.

${ }^{24}$ No Agamémnon de Ésquilo (vv. 75, 1651), os anciãos fazem-se acompanhar de bastóes e de espadas.

${ }^{25}$ Aristófanes, (Acarnenses, 412 sqq.); Rãs, 1063 sqq., atribui a Eurípides esta inovação do vestuário.

${ }^{26}$ Vide peça homónima de Sófocles, 161 sqq.

${ }^{27}$ Vide Sófocles, Édipo em Colono, 3-6.

${ }^{28}$ Vide Eurípides, Helena, 421, 554, 1079, 1204.

${ }^{29}$ Vide Eurípides, Orestes, 390-1.

${ }^{30}$ Entre outras razóes, Pickard-Cambridge (1953: 215-216) chama a atenção para o facto de Aristóteles, na enumeração das inovações preconizadas por Ésquilo, não mencionar esta. Assim, no entender do autor, o que terá acontecido é que, 50 anos depois da morte de Ésquilo, ter-se-á acreditado que o tragediógrafo teria vestido os reis e os heróis da tragédia com o syrma, um vestuário mais distinto do que o usado até então, e que 
adamente as Râs de Aristófanes (vv. 1060 sqq.), que o herói trágico esquiliano envergava túnicas majestáticas ${ }^{31}$, ao passo que, em Eurípides, o vestuário se caracterizava por uma maior simplicidade e uma maior aproximação à vida do quotidiano.

Para além das peças de vestuário já referenciadas, outras ainda podiam ocorrer, como a chlamys - usada sobretudo por soldados e mensageiros, e que consistia numa túnica relativamente curta e que ora surgia amarrada à volta do corpo por baixo de um dos braços e da cintura ora era fixada por um alfinete no ombro, caindo depois a direito ${ }^{32}$ - ou o kandys - que aparece nos vasos como sendo uma túnica, curta ou comprida, e que podia surgir com ou sem mangas ${ }^{33}$.

Outros efeitos podiam ainda ser conseguidos através da combinação de várias peças de vestuário com padrôes diferentes, como era comum acontecer, quando, por exemplo, sobre o chiton era usado o peplos ${ }^{34}$ com ou sem mangas. Pólux (4.116-7) refere-se, ainda, a outras peças de vestuário, infelizmente sem clarificar a que data é que pertencem, embora defenda que os figurinos usados no século $\mathrm{V}$ a.C. se mantiveram inalteráveis nos séculos seguintes. Esta opinião é, no entanto, contestada por Brooke (1962: 7), que advoga que basta comparar as figuras representadas no krater Prónomo de cerca de 400 a.C. ${ }^{35}$ e no mosaico dos ensaios, em Pompeios, para se ter uma noção das alteraçóes de estilo ocorridas ao longo de setecentos anos de performances teatrais, quer do mundo helénico quer do romano. Além disso, é evidente que, à medida que o drama grego foi evoluindo, da mesma forma que nas máscaras se acentuou o

por isso, mais tarde, foi entendido pelos autores que ele era o responsável pela invenção do figurino.

${ }^{31}$ Outros vasos mais tardios revelam o mesmo tipo de vestuário, como sendo o usado por reis, rainhas, príncipes e princesas, sacerdotes, profetas e mesmo pelos tocadores de flauta, que, a partir do século IV a.C., passaram a assumir um papel de destaque nas performances dramáticas.

${ }^{32} \mathrm{Na}$ opinião de Pickard-Cambridge (1953: 212), este era o vestuário que melhor se adequava a personagens a quem eram exigidos movimentos rápidos, como guerreiros ou caçadores.

33 Pickard-Cambridge (1953: 219) defende que o kandys, de origem persa, passou a ser usado como peça de vestuário típica das mulheres em Atenas, no século IV a.C., e que, por essa altura, os poetas trágicos o terão adotado ao teatro.

${ }^{34}$ Brooke (1962: 29) acredita que a conjugação destas duas peças era usada quer para proteger do frio quer como forma de acentuar a decoração.

${ }^{35}$ Cf. supra cap. 3 , n. 34. 
exagero, também o nível de decoração e o impacto visual do vestuário se foram salientando cada vez mais.

A par das roupas usadas ${ }^{36}$, os atores serviam-se também na sua indumentária de um sem número de outros acessórios, cada um dos quais com uma determinada simbologia. Para além do já referenciado recurso aos alfinetes, com todas as implicaçóes e funcionalidades já atrás descritas, era recorrente o uso de brincos, anéis e braceletes ${ }^{37}$, sobretudo por parte de rainhas ou de mulheres nobres, bem como de coroas e diademas, que não só serviam o propósito de distinguir personagens reais como de permitir, no caso das mulheres, segurar os véus por vezes também colocados. Outros adereços como escudos podiam igualmente ser apreciados no contexto teatral, quando, na peça em questáo, os atores ou elementos do coro representavam guerreiros, conforme acontece, por exemplo, nos Sete contra Tebas de Ésquilo ${ }^{38}$.

No que concerne à comédia, o vestuário típico usado caracterizava-se pela carga grotesca acentuada, visível quer na forma como o corpo aparecia enchumaçado quer no uso de uma túnica - chiton - justa e curta o suficiente para exibir o phallos ${ }^{39}$. Esta forma típica de vestir manteve-se durante a Comédia de Transição, pelo menos assim o demonstram várias estatuetas do século IV a.C. ${ }^{40}$, e, provavelmente, ter-se-á esbatido com Menandro e os seus sucessores, altura em que as personagens seriam representadas com trajes da vida quotidiana, apenas se mantendo algum grau de caricatura em determinadas figuras como escravos ou pais enfurecidos. Da mesma opiniáo partilham Csapo \& Slater (1994: 54), que defendem que, no período

${ }^{36}$ No entender de Brooke (1962: 18), de uma forma geral, o vestuário típico do teatro, desde o período ático até ao fim do império romano, caracterizava-se por ser relativamente simples, embora existisse uma grande variedade de adereços suplementares que tendiam a complicar o efeito geral.

${ }^{37}$ Cobras de ouro ou de bronze eram um dos motivos mais familiares das braceletes. Vide Brooke (1962: 61).

${ }^{38}$ Brooke (1962: 33) defende que, na peça referenciada, Ésquilo descreve os escudos à maneira homérica, principalmente como são apresentados no canto II da Ilíada.

${ }^{39}$ São inúmeros os passos que testemunham o uso deste figurino típico da comédia: Aristófanes, Acarnenses, 158, 592, 1216; Paz, 1349; Lisistrata, 982 sqq., 1073 sqq.; Mulheres que celebram as Tesmofórias, 62, 643 sqq.

${ }^{40}$ Exemplo disso é a estatueta em terracota, representativa de Héracles, que se encontra em Nova Iorque, no Metropolitan Museum of Fine Art (Reprod. Pickard-Cambridge 1953: fig. 84) 
da Comédia Nova, cerca de 320 a.C., o phallos e o pequeno chiton desapareceram e as roupas enchumaçadas passaram a ser usadas apenas por escravos.

Pólux (4.119-20) deixa-nos também testemunho dos figurinos cómicos, mas, mais uma vez, sem qualquer indicação cronológica, pelo que se desconhece a que época concreta o autor se refere ${ }^{41}$. De qualquer forma é possível estabelecer algumas peculiaridades na forma de vestir de determinadas personagens. Assim, segundo o autor, os homens velhos usavam um himation branco, os jovens um vermelho ou púrpura, enquanto os parasitas envergavam um preto ou cinzento. Quanto aos escravos, sobre a exomis - uma veste branca e inteiriça com nenhum tipo de costuras do lado esquerdo - traziam um himation branco e curto. Algumas mulheres vestiam um chiton com uma bainha púrpura que chegava ao chão, ao passo que as jovens trajavam de branco. Quanto aos pornoboskoi ou 'proxenetas', usavam uma túnica colorida com um manto florido por cima.

Outro tipo de figurinos podia ainda surgir na comédia, tendo em conta as personagens representadas pelos elementos do coro. Assim terá existido um figurino específico para caracterizar as Vespas $^{42}$ de Aristófanes ou as Aves ${ }^{43}$ do mesmo comediógrafo.

Relativamente ao drama satírico, o vaso Prónomo ${ }^{44}$ dá-nos conta da forma típica como os elementos do coro se caracterizavam, já que no mesmo se representa um coro satírico, vestindo calçóes de pelo ${ }^{45}$ com rabos de cavalo e ostentando falos de couro. O seu líder, Sileno, enverga uma vestimenta de lá ou de pelo, com uma pele de leopardo por cima do ombro.

${ }^{41}$ Pickard-Cambridge (1953: 235) acredita que, provavelmente, estes figurinos dizem respeito à fase mais convencional do teatro.

42 Vide Aristófanes, Vespas, 1071-3; 1104-5.

${ }^{43}$ Cada um dos elementos tinha que representar um tipo diferente de ave. Cf. supra cap. 3, 60.

${ }^{44}$ Cf. supra cap. 3, n. 34.

${ }^{4}$ Existe, no entanto, alguma individualidade na caracterização dos vários elementos, porquanto os padróes e os materiais utilizados na feitura dos calçóes diferem ligeiramente. 


\section{1 - CalÇAdo}

A encerrar esta abordagem do vestuário teatral, impóe-se ainda uma breve reflexão sobre um aspeto que o completava: o calçado usado nas representaçóes. A grande dificuldade a este respeito reside no caso dos atores trágicos, em especial no que diz respeito à correta identificação do coturno - termo que, por sinédoque, passou à linguagem corrente para designar assuntos de natureza trágica ou que exigem uma particular seriedade no tratamento. Durante anos ${ }^{46}$, acreditou-se que o calçado usado pelos atores trágicos se caracterizava pelo uso de solas extremamente elevadas (entre dez e vinte e cinco centímetros), o chamado kothornos, aparentemente visível na conhecida estatueta de Rieti, um marfim conservado no Museu du Petit Palais (reprod. Csapo \& Slater 1994: Pl. 10D) ${ }^{47}$.

Mas hoje sabe-se que esta especificidade do calçado vigorou apenas no período helenístico, no seguimento da introdução do proscénio e de edifícios teatrais com maior capacidade, já que, para atenuar o acentuar da distância entre audiência e atores, foi necessário conferir a estes altura e majestade extra. Assim, no século $\mathrm{V}$ a.C., parece provável que os atores usassem um tipo de calçado simples e maleável que chegava a uma determinada altura da perna e cuja biqueira ficava relativamente levantada. A sola, no entender de Brooke, fazia parte da mesma peça com que se fabricava a bota e era fina o suficiente, de forma a não impedir os movimentos. É com este tipo de calçado que os membros de um coro feminino aparecem representados nos

${ }^{46}$ Para esta teoria contribui também o facto de a tradição, baseada numa passagem corrupta da Vida de Ésquilo, ter atribuído a este tragediógrafo a criação dos kothornoi.

47 Segundo Pickard-Cambridge (1953: 228), essa teoria resultou da análise indiscriminada, em termos cronológicos, das fontes. O mesmo estudioso defende, inclusive, que existem determinadas cenas trágicas, como a da passagem sobre o tapete purpúreo de Agamémnon ou cenas que exigiam movimentos rápidos e/ ou violentos dos atores, que seriam impraticáveis com este tipo de calçado tâo excêntrico. Além disso, hoje em dia, existem inclusivamente teses sobre a estátua de Rieti que apontam no sentido de considerar como pegas para manter a estátua em pé aquilo que parece ser a sola do calçado. 
fragmentos de um vaso de cerca de 470 a.C. ${ }^{48}$ e também na pelike ática de Boston ${ }^{49}$.

Outras botas eram atadas à frente, deixando, às vezes, os dedos de fora, e distinguiam-se por serem ornamentadas no topo com a pele de algum animal. Existem, ainda, vários va$\operatorname{sos}^{50}$, onde é possível observar outros tipos de calçado: alguns fechados e ajustados, outros mais largos e folgados em cima, sendo uns mais decorados do que outros.

Quanto à comédia, é sabido que o calçado usado eram as embades - o calçado de todos os dias, salientando-se também, por esta via, a natureza menos elevada do assunto tratado.

${ }^{48}$ Cf. supra cap. 3, n. 3.

${ }^{49}$ Cf. supra cap. 3, 60. Diónisos é frequentemente representado a usar este calçado tipicamente feminino.

${ }^{50}$ Exemplo disso é uma ânfora ática de figuras vermelhas do séc. VI a.C., conservada no British Museum (reprod. Pickard-Cambridge 1953: fig. 197), que representa Diónisos, e um psykter ático pelo pintor Dúris de c. 490-480 a.C., patente no mesmo museu (reprod. Pickard-Cambridge 1953: fig. 199), onde figuram Hermes e os sátiros. 
(Página deixada propositadamente em branco) 
5 - Atores 
(Página deixada propositadamente em branco) 


\section{1 - NÚMERO}

A origem dos atores na Antiguidade Clássica está intimamente associada às origens do próprio teatro. Segundo a tradição, terá sido Téspis o primeiro a distanciar-se do coro e a individualizar-se como ator ${ }^{1}$. Ésquilo terá introduzido o segundo e Sófocles o terceiro ator ${ }^{2}$, número que se fixou como limite e que náo mais seria ultrapassado, durante a vigência do teatro na antiga Grécia $^{3}$. Assim, é notório que a maior parte das tragédias de Ésquilo foram concebidas de forma a que apenas dois atores surgissem como intervenientes ${ }^{4}$, ao passo que, em Sófocles, é visível a necessidade de três.

Segundo D’Arnott (1989: 45), esta limitação do número de atores poderá advir de várias razões: das próprias origens do drama e do facto de inicialmente o coro ter um papel preponderante, pelo que o número de atores terá sido reduzido ao indispensável; do facto de o apogeu do teatro ter sido relativamente curto para permitir grandes inovações, já que, falecidos Sófocles e Eurípides, assistiu-se essencialmente no século IV a.C. à reposiçáo de peças dos grandes tragediógrafos do século $\mathrm{V}$ a.C.; de ser um fator importante para promover a competição; do facto de os festivais acarretarem despesas avultadas e de, assim, poder evitar-se, de alguma forma, uma sobrecarga de custos e, acima de tudo, por uma questão estética, já que os Gregos pareciam reconhecer grandes virtudes dramáticas na economia e, por essa razáo, ainda que tendo disponíveis três atores, em muitas peças, predominam as estruturas binárias de intervenção 5 .

A imposição de três como número máximo de atores implicava que os mesmos se tivessem de desdobrar, de forma a poderem corresponder ao número de personagens existentes em cada peça ${ }^{6}$ e, assim, suprir todas as necessidades e, por

${ }^{1}$ A situação remonta a 534 a.C., altura em que Atenas se encontrava sob a liderança de Pisístrato.

${ }^{2}$ Cf. Aristóteles, Poética, 4.1449a16.

${ }^{3}$ Cf. Bieber (1961: 37-8).

${ }^{4}$ Por exemplo, os Sete Contra Tebas. Há, no entanto, exceçóes como o Agamémnon, onde Ésquilo recorre à introdução de um terceiro ator, para desempenhar o papel de Cassandra, como forma de criar um efeito especial.

5 São disso exemplo Alceste e Medeia de Eurípides.

${ }^{6}$ Esta situação era facilitada pelo facto de os atores usarem máscara e, por isso, alterando a mesma, terem a possibilidade de desempenhar vários papéis de forma verosímil. Segundo Rehm (1992: 27), por exemplo, 
isso, por vezes, a mesma personagem podia também ser desempenhada por vários atores. Pickard-Cambridge (1953: 143) defende que foi o que aconteceu no Édipo em Colono, no que concerne à figura de Teseu, ao contrário de outros estudiosos ${ }^{7}$ que reclamam a presença de pelo menos mais um ator, para facultar o desempenho de todas as personagens. De qualquer forma, a ser assim, o autor acredita que, do verso 1096 ao 1555, Ismena tenha sido representada por aquilo a que hoje denominamos de figurante, e que não era mais do que uma personagem muda $^{8}$, vestida com a sua roupa. Outros exemplos do recurso a estes elementos por parte de Sófocles podem ser encontrados, quer no final do Rei Édipo, no que diz respeito às filhas do mesmo, quer no Ájax (vv. 1168 sqq.), relativamente à personagem Tecmessa. No entanto, terá sido Eurípides $^{9}$ o tragediógrafo a fazer maior uso deste expediente, nomeadamente no que diz respeito à representação de crianças, já que, como não podiam ser adultos a interpretar estas personagens, eram no entanto eles que emprestavam a voz aos rapazinhos que, como figurantes, desempenhavam estes papéis ${ }^{10}$. De qualquer forma, em cena, podiam apenas contracenar tantas personagens quantos atores, sem englobar as personagens mudas e, por isso, em Sófocles, são reconhecidas como triangulares as cenas-chave onde, geralmente, são apresentadas três perspetivas distintas ${ }^{11}$.

Relativamente ao drama satírico, presume-se, tendo em conta o Ciclope de Eurípides, o único texto deste género

nos Persas, a mais antiga tragédia subsistente, eram necessários apenas dois atores e, assim, provavelmente Ésquilo terá desempenhado o papel de Mensageiro (pelo menos a maior parte dele) e do fantasma de Dario, enquanto o outro ator terá assumido as personagens da rainha e do filho, Xerxes. Sobre a distribuição de papéis nas peças dos maiores tragediógrafos, vide Pickard-Cambridge (1953: 139-147).

7 Entre eles está Rees (1907: 79), que, ao não aceitar a imposição do limite de três atores por peça, defende a impressionante conclusão de que o Édipo em Colono terá sido representado por seis atores.

${ }^{8}$ Segundo Csapo \& Slater (1994: 221), o número de figurantes que podia surgir em cada peça era, em princípio, ilimitado.

${ }^{9}$ Vide Alceste, 393-415, Andrómaca, 494-545 e Suplicantes, 1114-64.

${ }^{10}$ Pickard-Cambridge (1953: 144) coloca também a hipótese de ser o próprio rapaz a emprestar a voz à personagem, por exemplo na Alceste, 393-415, de Eurípides.

${ }^{11}$ Vide Filoctetes (o debate sobre o corpo de Ájax pressupunha um proponente, um oponente e um mediador), ou a cena onde o mensageiro 
sobrevivente na íntegra, que também o limite de atores fosse três. Já na comédia, não há tantas certezas de que esta regra se aplicasse, porquanto algumas peças de Aristófanes apresentam dificuldades relativamente à distribuição de papéis apenas por três elementos. De qualquer forma, Pickard-Cambridge (1953: $138,158)$ admite que havia sempre a possibilidade de complementar a disponibilidade de apenas três atores, com o recurso a personagens mudas, e sugere que Aristófanes usufruiria de liberdade suficiente para introduzir um outro ator, como, por exemplo, nas Vespas, onde são necessários pelo menos quatro ${ }^{12}$. A mesma situação é visível também na comédia nova, com Menandro ${ }^{13}$.

\section{2 - DesignaÇáo}

Nos primeiros tempos de vida dos atores, desconhece-se de que forma estes seriam designados, até porque o seu papel era pouco relevante ${ }^{14}$, sendo que parece que funcionariam, meramente, como veículo transmissor da mensagem do poeta, sem que tivessem a oportunidade de contribuir com algo original ${ }^{15}$. Em meados do século $\mathrm{V}$ a.C., quando o ator deixou de desempenhar apenas o papel de um mero declamador, passando a contracenar e a dialogar com outros atores e provavelmente com o coro, a palavra usada regularmente para o designar, fosse trágico ou cómico, protagonista ou não, era hypokrites, vocábulo que veio a dar origem, em português, ao termo hipócrita ${ }^{16}$. O ator era pois aquele que fingia ser a personagem que a peça retratava e a audiência tinha consciên-

conta a verdadeira história a Jocasta e a Édipo, da qual cada um retira diferentes ilaçôes, no Rei Édipo de Sófocles.

${ }^{12}$ Sobre a distribuição dos papéis na comédia, vide Pickard-Cambridge (1953: 148-151).

${ }^{13}$ Csapo \& Slater (1994: 222) não partilham desta opinião, já que advogam que a regra dos três atores era cumprida nas peças de Menandro, situação que terá resultado do facto de se ter instituído o concurso de atores cómicos, nas Grandes Dionísias, cerca de 328-312 a.C.

${ }^{14}$ Segundo Capone (1935: 11), a evolução do ator foi-se desenvolvendo de forma gradual - de interlocutor do coro, na pessoa do corifeu, a elemento indispensável do diálogo.

15 Vide D’Arnott (1989: 48).

${ }^{16}$ Ghiron-Bistagne (1976: 116) defende que no século IV a.C. a tragédia era vista pelos seus intérpretes como um exercício de estilo e, sem dúvida, por essa razão o vocábulo veio a significar hipócrita, já que o ator representava sob uma máscara e a sua arte consistia essencialmente, como 
cia de que assim era, já que, no dizer de Johnson (apud Bain 1977: 6), é falso que qualquer representação fosse confundida com a realidade, uma vez que os espectadores tinham sempre a noção, do princípio até ao fim, de que o palco era apenas o palco e os atores apenas atores. Da mesma opiniáo partilha Capone (1935: 26), que defende que o ator tinha o ofício e a obrigação de interpretar e recriar, e de dar uma nova vida, sob a forma dramática e representativa, à visão do poeta. Daí que exatamente por esta razão as qualidades e o talento dos atores fossem apreciados e julgados e, deste reconhecimento, resultasse a designação dos vencedores.

A forma verbal hypokrinomai começou por significar, na Iliada (e.g. 7.407; 12.228) e na Odisseia (e.g. 19.535, 555), 'interpretar sonhos' ou 'responder a questóes'. Com o significado de 'representar', o verbo aparece pela primeira vez, na literatura conservada, em meados do século IV a.C. ${ }^{17}$, mas Pickard-Cambridge (1953: 127) acredita que a designaçáo de ator como hypokrites seria já usada no século $\mathrm{V}$ a.C. e que não haveria nenhum outro termo para denominar atores, em geral, incluindo os protagonistas. A atestá-lo está o facto de ser com este sentido que a palavra é usada por Platão (Banquete, 194b) e outros autores, sendo também sob esta forma que aparecem mencionados os protagonistas vitoriosos (e.g. I.G. II ${ }^{2}$. 2318), depois que se instituiu a competição dos atores trágicos, cerca de 449 a.C.

Durante o século IV a.C., outros vocábulos são utilizados como o de tragodos e komodos para designar, respetivamente, ator trágico e ator cómico. No entanto, nessa altura o significado mais recorrente destas palavras era o da tragédia e comédia ${ }^{18}$, coreuta trágico e cómico, ou mesmo, tragediógrafo e comediógrafo $^{19}$. Só a partir de 280 a.C. os termos começam a ser usados regularmente para denominar atores, sobretudo os protagonistas das peças antigas, nomeadamente nos registos dos vencedores, quer nos festivais de Delfos e Delos, quer noutros locais, sendo

demonstra Diderot no Paradoxo sobre a Comédia, em representar algo que não tinha em conta o gosto dos espectadores.

${ }_{17}$ Demóstenes, Sobre a falsa embaixada, 246; Aristóteles, Ética a Nicómaco, 7.1147a23; Retórica, 3.1403b26-33.

${ }^{18}$ Vide Ésquines, Contra Ctesifonte, 34, 41, 45, 154.

${ }^{19}$ Ghiron-Bistagne (1976: 124) defende, no entanto, que no século IV a.C. estas palavras eram usadas mais recorrentemente para designar ator trágico e ator cómico. 
que continuou a utilizar-se o substantivo hypokrites quando o objetivo era mencionar os outros atores, inclusivamente o protagonista de peças novas. Segundo Ghiron-Bistagne (1976: 123), a diferença de apelidaçôes resultava do facto de os atores das peças antigas terem sido, muitas vezes, simultaneamente encenadores, já que, nos primeiros tempos do teatro, era comum os tragediógrafos participarem nas peças como atores, inclusivamente desempenhando os papéis principais. Assim procedeu Ésquilo. Já Sófocles não o terá feito, à exceção de pequenos quadros, onde terá surgido como figurante - a tocar cítara, por exemplo na tragédia Tâmiras - por causa, segundo a tradição, da sua débil voz ${ }^{20}$. Também de Eurípides não há sinais de que tivesse representado ${ }^{21}$, e acredita-se que apenas ocasionalmente tenha dirigido peças da sua autoria.

Outros termos, embora pouco frequentes, podiam ainda ser utilizados para designar os atores, como os vocábulos protagonistes, deuteragonistes e tritagonistes, ainda que, no caso de protagonistes e deuteragonistes, apareçam registos do seu uso noutro tipo de concursos. E embora seja comum associar-se estes termos ao significado que hoje eles possuem ('protagonista', 'deuteragonista' e 'tritagonista'), Pickard-Cambridge (1953: 136), baseado em Plotino (3.2.484), aventa a hipótese de estas palavras terem começado por ser usadas para mencionarem a divisão da profissão de ator em três classes, que terá ocorrido durante o século III d.C., e não para designarem a importância relativa de cada ator numa determinada peça, como geralmente se crê.

Quanto aos figurantes, eram designados de kopha prosopa ${ }^{22}$, por serem considerados acessórios (parachoregemata), enquanto, no dizer de Ghiron-Bistagne (1976: 117), o hypokrites era o ator que fazia uso ativo da voz e dos gestos.

${ }^{20}$ Vide Vida de Sófocles, 4.

${ }^{21}$ A primeira vez que Eurípides concorreu às Grandes Dionísias, em 455 a.C., foi apenas cinco anos antes de deixar de ser possível os poetas desempenharem o papel de protagonistas nas suas próprias composiçóes.

22 Cf. Cícero, Cartas a Atico, 13.19.3. 


\section{$5.3-\mathrm{Voz}$}

A voz era, sem dúvida, um dos maiores requisitos do ator ${ }^{23}$ e o seu melhor veículo de transmissão de mensagens, emoções, sentimentos. Num espaço que ditava a distância física, por vezes acentuada, entre atores e espectadores, e onde o uso da máscara impedia a visualização de expressóes faciais, o ator tinha de se servir das palavras para transmitir o seu estado de espírito e era também por intermédio dessas palavras que o espectador vivia o momento e criava o ambiente intrínseco à peça a que assistia ${ }^{24}$; daí que o maior critério para julgar o talento de um ator fosse, sem dúvida, a qualidade da $\operatorname{voz}^{25}$, que se pretendia com características de megalophonia, euphonia e lamprotes. Assim, e segundo D’Arnott (1989: 79), tanto no século IV como no $\mathrm{V}$ a.C., boa projeção vocal, eufonia e limpidez na voz eram os grandes atributos de um ator ${ }^{26}$ e, por esta razão também, qualquer falha cometida por este era severamente condenada pela audiência. Pólux (4.114) lista um conjunto de falhas em que, em termos vocais, um ator podia incorrer ${ }^{27}$.

Esta importância extrema da voz levava a que houvesse certos cuidados ${ }^{28}$ com a mesma e exigia treinos constantes.

${ }^{23}$ Cf. Rehm (1992: 50); Rispoli (1998: 56). Pickard-Cambridge (1953: 165) acrescenta que era igualmente importante a beleza da tonalidade e a adaptação à personalidade da personagem representada, daí que Aristóteles reforçasse a importância para o ator das figuras de estilo bem como colocasse alguma ênfase na capacidade que este devia possuir de repetir o mesmo em tonalidades diferentes. Vide Aristóteles, Poética, 19. 1456b; Retórica, 3.12.

${ }^{24}$ D’Arnott (1989: 93) acrescenta que, na tragédia, a linguagem definia e coloria a imaginação da audiência, pintando imagens na fachada em branco da skene, tal como acontecia com as máscaras que, através das palavras, ganhavam novas expressōes. Sobre a importância das palavras no teatro grego, vide cap. 7, 135-136.

${ }^{25}$ A importância da voz é defendida por autores como Aristóteles (Ética a Nicómaco, 3.1118a), Pseudo-Plutarco (Vida dos Dez Oradores, 848b) ou Zenão (apud Diógenes Laércio, Vidas e opiniōes de filósofos eminentes, 7.20).

${ }^{26}$ As qualidades da voz passavam também, no entender de Rispoli (1998: 56), não só pela correta dicção como também pela capacidade de produzir sons inarticulados e mecânicos, como acontece no lamento de Ájax, na peça homónima de Sófocles (vv. 305 sqq.).

27 Entre elas conta-se a de falar com voz de mulher, e terá sido por isso que Sófocles não teve uma grande intervenção como ator.

${ }^{28}$ Aristótles (Problemas, 11.901b5-16), refere a necessidade de se fazer dieta para não arruinar a voz. Por exemplo, a carne assada náo era considerada um alimento adequado para quem tinha de falar em público. 
De entre estes, conta-se, por exemplo, o exercício de subir e descer escadas, bem como a prática de dietas. Além disso, antes do início das performances e durante os intervalos, os atores tinham a preocupação constante de aquecer a voz. É bastante conhecida a este respeito a tradição (Pólux, 4.88) que dá conta do facto de o ator Hérmon ter falhado a sua entrada em cena, exatamente porque estava a aquecer a voz no exterior do teatro e não se apercebeu de que tinha chegado a sua vez de intervir.

Infelizmente, não se sabe exatamente de que forma o ator fazia uso da sua voz, mas é certo que, para além de ter que a projetar bem e de ter a obrigação de garantir uma boa dicção, tinha também de saber cantar, algo que fazia quer a solo ${ }^{29}$ quer em conjunto com o coro, uma vez que a prestação dos atores gregos incluía trechos sem acompanhamento musical - kata$\log e^{30}$ - trechos com acompanhamento musical - recitativos - parakataloge ${ }^{31}$ - e partes cantadas - melos ${ }^{32}$ - existentes sobretudo em momentos reflexivos e de grande emoção.

Conforme se depreende, a música era pois um dos requisitos fundamentais do espetáculo. Aristóteles (Poética, 6.1450a8) considera-a um elemento constitutivo da tragédia, a par do mito, do caráter, da linguagem, do pensamento e do espetáculo, mas de todos eles o mais agradável (Poética, 6.1450b16). Com o passar do tempo, e pelo facto de o destaque ter sido transferido para os atores, as partes cantadas passaram a estar mais associadas a estes elementos, nomeadamente através da interpretação de árias, e menos ao coro, cujas manifestações, na Época Helenística, subsistiam apenas nos interlúdios. É também por esta altura que os músicos veem a sua importância crescer, de tal forma que se acredita que, quando no século IV a.C. se instituíram as companhias profissionais, estas eram também constituídas por flautistas, já que a flauta era o instrumento de eleição ${ }^{33}$, quer da tragédia ${ }^{34}$ quer da comédia, e, segundo

${ }^{29}$ Por exemplo, Íon e Electra, nas peças de Eurípides a que emprestam o nome, entram em cena, cantando uma monódia, à semelhança da entrada do coro nos párodos.

${ }^{30}$ Hesíquio, s.v. kataloge.

${ }^{31}$ Aristóteles, Problemas, 19.918a10-13.

${ }^{32}$ Aristóteles, Poética, 1.1447b25.

${ }^{33}$ Cf. Plutarco, Sobre o E de Delfos, 394c; Escólio a Aristófanes, Nuvens, 313.

${ }^{34}$ Vide Eurípides, Bacantes, 117. 
Aristóteles (Problemas, 19.922a1-20), o que melhor se adequava à voz por esta ser também um instrumento de sopro.

De facto, a importância de que este elemento se revestia para os Gregos ditou a longa carreira, por exemplo, de Sátiro, não só por ser um dos melhores flautistas do seu tempo (entre os séculos III - II a.C.), mas também por ser um músico completo, capaz de tocar outros instrumentos, incluindo a cítara ${ }^{35}$, instrumento muito menos recorrente, mas que também podia surgir para criar um efeito especial ${ }^{36}$, como aconteceu na obra Tâmiras de Sófocles, onde terá sido tocada pelo próprio. Há ainda referência a outros ${ }^{37}$ tais como a syrinx - um tipo específico de flauta ${ }^{38}$-, ou o trigonos - um instrumento de forma triangular, semelhante à harpa.

Para além do melos, constituído por metros líricos, é possível ainda distinguir, como modos de elocução, a parakataloge, cujo metro utilizado variava entre os tetrâmetros iâmbicos, os tetrâmetros trocaicos e os tetrâmetros anapésticos, e a kataloge, sendo que neste caso o metro empregado era o trímetro iâmbico ${ }^{39}$ (metro constituído por seis iambos), por ser aquele que mais se aproximava do usado na linguagem coloquial e por isso o que melhores condiçóes tinha de garantir maior verosimilhança. No que concerne à parakataloge, D'Arnott (1989: 84) considera que a sua presença era uma constante, uma vez que defende que muitos dos diálogos gregos podem muito bem ter sido musicados, de forma a assemelharem-se mais ao recitativo da ópera do que ao que hoje concebemos como diálogo falado, ao passo que Pickard-Cambridge (1953: 162) é mais comedido, ao afirmar que não se deve ter a veleidade de considerar que todos os metros iâmbicos encontrados em combinação com metros líricos estavam ao serviço do recitativo; antes deve ter-se presente que os poetas usufruiriam de

35 Segundo Chanzedon (1998: 44), estas qualidades de músico, principalmente de flautista, permitiram-lhe não só obter glória e prestígio, mas também simplesmente viver.

36 Pickard-Cambridge (1953: 163) acredita que o seu uso estivesse confinado ao acompanhamento de monódias.

37 Vide Comotti (1989: 52).

${ }^{38}$ E.g. Eurípides, Alceste, 576; Ín, 498; Ifigénia em Táuride, 1125; Helena, 1482.

39 Por vezes, em momentos de particular intensidade, outros metros podiam ser usados, como acontece, por exemplo, com Eurípides ao usar o tetrâmetro trocaico. Vide Eurípides, Bacantes, 604 sqq. 
liberdade suficiente para decidir que modalidade melhor se adequaria a determinada parte.

A kataloge podia ainda categorizar-se em discursos, diálogos e debates. Relativamente aos primeiros, visíveis frequentemente na tragédia e na comédia, resultavam da ligaçáo intrínseca entre o teatro e a vida pública e política. Assim, apresentavam a mesma estrutura dos proferidos quer na assembleia quer nos tribunais ${ }^{40}$. Em relação ao diálogo, este seguia uma estrutura rígida, muito diferente dos diálogos reais, designada de stichomythia - o que literalmente significava contar uma história linha a linha - e que consistia na alternância de emissor verso a verso ${ }^{41}$. Este facto permitia que o espectador, familiarizado com este esquema, facilmente se apercebesse de qual a personagem que falava. É neste sentido que D’Arnott (1989: 99) concebe esta rigidez, já que não seria entendível que os Gregos tivessem preocupaçôes de verosimilhança com a realidade na escolha do metro a usar nestas circunstâncias - o trímetro iâmbico - e não as tivessem ao recorrerem a um esquema rítmico tão artificial. Há, no entanto, outras visôes, como a de Thomson (1941: 189-91), que acredita que a stichomythia era o resultado da influência de alguma liturgia pré-dramática, já que o estudioso defende que esta estrutura passou intacta para as composiçôes dramáticas, sendo que coro e atores assumiam os papéis de sacerdote e iniciado, colocando as questóes e dando as respostas no mesmo ritmo.

Na comédia, ao contrário da tragédia, haveria pausas entre a alternância dos emissores, para permitir que os espectadores se pudessem rir.

No que concerne ao debate (agon), que constituía também um testemunho da natureza política da tragédia, já que, ao servirem-se dele, as personagens defendiam os seus pontos de vista como se estivessem perante um tribunal, argumentando e contra-argumentando, este desempenhava um papel preponderante quer em tragédias ${ }^{42}$ quer em comédias, sendo que

${ }^{40}$ Vide o discurso do sacerdote de Zeus, no prólogo do Rei Édipo de Sófocles.

${ }^{41}$ Este era o esquema mais comum. Há, no entanto, situações em que a alternância de emissor se dava de dois em dois versos (dístico). Outras vezes, mais raramente ainda, e de forma a proporcionar um ritmo mais acelerado, a alternância ocorria de meio em meio verso (hemistíquio).

${ }^{42}$ Vide Euménides, o debate entre Atena, Apolo e as Fúrias. 
nestas últimas podia, inclusivamente, fazer-se acompanhar de violência física.

Uma outra particularidade do discurso dos atores é que não havia grandes diferenças de vocabulário e de dicção entre homens velhos, novos, mulheres, escravos e guerreiros ${ }^{43}$, o que estava em consonância e em concordância com o facto de serem homens a representar mulheres e, desta forma, evitava-se alguma descaracterização que podia decorrer da diferença existente entre a tonalidade masculina e a feminina. Segundo D’Arnott (1989: 87), esta proeminência da masculinidade terá influenciado a escrita e daí muitas personagens femininas, como Clitemnestra, revelarem características próprias do sexo masculino, até porque, como Zeitlin (1990: 65) afirma, pelo facto de qualquer personagem feminina ser representada por um homem, nunca era uma mulher que falava ou agia mas sempre o homem que a personificava. Além disso, os atores trágicos não falavam com dialetos ${ }^{44}$, mesmo quando as personagens existentes na peça a isso obrigavam. Já na comédia, género pautado por um maior realismo, Aristófanes recorreu várias vezes ao seu uso ${ }^{45}$, como forma de provocar o riso.

Com o passar do tempo, a tendência foi para exagerar nas capacidades vocais e no próprio uso da voz, conforme pode ser atestado por várias histórias, como a de Parménon, que imitava na perfeição porcos ${ }^{46}$, e foi exatamente esta vulgarização que levou Platão (República, 3.397a), no século IV a.C., a afirmar que tudo era imitado através da voz e dos gestos, sendo que à narrativa cabia apenas uma pequena parte. De qualquer forma, a imitação de toda a espécie de animais era típica da comédia, como o pio das corujas, na Lisístrata (v. 761), ou o latir de um cão, nas Vespas (v. 903), ambas peças de Aristófanes.

${ }^{43}$ Cf. Rehm (1992: 50).

${ }^{4}$ Segundo D’Arnott (1989: 88), nas Troianas de Eurípides, Menelau, um espartano, Hécuba, uma troiana e Agamémnon, um argivo, falavam todos com o mesmo grego ático-iónico.

${ }^{45}$ Por exemplo, nos Acarnenses, o Megarense e o Beócio falavam com o acento típico da sua região de origem. Também na Lisístrata, havia distinção de pronúncia entre Atenienses e Espartanos.

${ }^{46}$ Vide Plutarco, No Banquete, 674b. 


\section{4 - Gestos}

A voz era realmente o atributo mais importante do ator, mas outros havia também importantes como o schema, e é neste sentido que Gigante (1989: 19) defende que, apesar de a palavra ser insubstituível, a ação dramática não podia resultar só dessa mesma palavra, mas de uma série de outros elementos que a reforçavam: a voz, a máscara, o gesto, a melodia e a dança. Na mesma esteira, Zeitlin (1990: 71-2) sustenta que a ênfase do teatro devia recair inevitavelmente sobre o corpo humano e sobre a forma como este representava a personagem que encarnava, com poses estilizadas, gestos e atitudes.

Assim, e apesar da quase inexistência de didascálias ${ }^{47}$, uma vez que as mais das vezes eram os próprios poetas que encenavam a peça, é possível reconstruir a movimentação cénica dos atores a partir de indicaçóes dadas pelos próprios ${ }^{48}$, de referências presentes em escólios, das representaçóes dos vasos e ainda tendo em conta uma forma de arte muito semelhante, a oratória ${ }^{49}$, já que parece ser comum a ambas as artes, por exemplo, falar com determinado tipo de poses, colocando a máo por baixo da túnica - como era típico da oratória e como se pode visualizar em vasos gregos de representaçóes teatrais - ou executar movimentos circulares - situação que se depreende ter acontecido não só no contexto teatral como também na realidade dos tribunais. Além disso e, segundo D’Arnott (1989: 55), os gestos típicos da oratória romana, descritos por Quintiliano, parecem ter uma correspondência direta com gestos das máos (cheironomia) representados em vasos gregos que, no entender de Capone (1935: 34), constituíam uma arte por si só.

De qualquer forma, fosse qual fosse a natureza dos gestos, estes necessitavam de ser executados em grande escala, de forma a serem percetíveis pelos espectadores mais distantes e, por isso, é expectável, na opinião de D’Arnott (1989: 59), que eles tivessem mais um cariz funcional do que legitimidade teatral, até porque eram resultado de um sem número de convençóes.

${ }^{47}$ Existem apenas cinco exemplos na tragédia, todos das Euménides de Ésquilo; dois em dramas-satíricos, os Batedores de Sófocles e o Ciclope de Eurípides; e sete na comédia, todos dos Acarnenses de Aristófanes. A maior parte destes exemplos são de caráter sonoplástico.

${ }^{48}$ Sobre a importância da palavra no teatro grego, vide cap. 7, 135-136.

49 Segundo D'Arnott (1989: 51), para os Gregos a oratória e a representação teatral resultavam de perspetivas diferentes de abordagem da mesma arte, perante um tipo de audiência também ele diferente. 
Assim, e segundo Stanford (1983: 85-87), os gestos convencionais para traduzir a dor extrema eram: esconder a cara, bater com a máo na cabeça e no corpo, arrancar ou cortar o cabelo $^{50}$, arranhar a cara e rasgar as próprias roupas ${ }^{51}$. Noutras ocasióes, como acontece com a heroína da Hécuba de Eurípides (vv. 486-7), este sentimento podia também ser representado através da queda da personagem no chão ou simplesmente com a personagem prostrada, com olhar cabisbaixo ${ }^{52}$.

Para demonstrar uma atitude de súplica, as mulheres e crianças, angustiadas, ajoelhavam-se e tocavam as faces ou a barba daqueles a quem suplicavam, ou então puxavam-lhes as vestes ${ }^{53}$. $\mathrm{Na}$ súplica extrema por piedade, as mulheres desnudavam os seios ${ }^{54}$, embora não pareça credível que esta situação ocorresse no teatro, porquanto os atores eram homens e a maior parte da audiência não poderia visualizar este pormenor, à distância que se encontrava. Daí que Stanford (1983: 86) sugira que devia apenas ser simulado o gesto de despir. Quanto à forma de transmitir que uma determinada personagem estava a chorar ${ }^{55}$, era possível fazê-lo apenas por palavras, uma vez que a máscara impedia a visualização dessa e de qualquer outra expressão facial. Já para evidenciar que a personagem estava a rezar, um dos gestos mais comuns consistia nos braços esticados para a frente e para cima, com as palmas da mão voltadas também para cima. No entanto, quando as palavras eram dirigidas a um deus ctónico, o gesto convencional consistia no bater do pé no chão por parte da personagem ${ }^{56}$.

No que respeita ao medo e ao terror, era frequente traduzir estas emoções colocando o braço a meia distância, com a mão de lado a revelar uma atitude de repulsa em relação ao elemento terrífico, como se pode visualizar no kalyx krater do estilo Gnatia, de Ruvo, conservado em Leninegrado (reprod. Pickard-Cambridge 1953: fig. 177) que representa a Pítia

${ }^{50}$ Esta atitude era assumida, principalmente, para revelar o luto que a personagem vivia. Havia, no entanto, outras formas de o demonstrar, como sendo esconder a cara. Vide Eurípides, Orestes, 280-1; 294-5, quando o herói pergunta à irmá por que razáo ela chora e encobre a cabeça.

51 Vide Ésquilo, Coéforas, 22-31; Eurípides, Electra, 146-50.

52 Vide Sófocles, Antígona, 441.

${ }^{53}$ Vide Antígona, no Édipo em Colono de Sófocles, 1414.

${ }^{54}$ Vide Hermíone, na Andrómaca de Eurípides, 822-3.

55 Vide Ésquilo, Coéforas, 185-6.

56 Vide Eurípides, Medeia, 1056 sqq. 
a assumir esta atitude em relação às Fúrias, no início das Euménides de Ésquilo.

Quanto à alegria, geralmente era expressa através de largos passos de dança ou saltos, como acontece com o coro na Electra de Eurípides (vv. 859-61), quando proclama que vai demonstrar a sua alegria, dando saltos até ao céu. Os movimentos frenéticos serviam também para demonstrar pânico, doença ${ }^{57}$ ou loucura ${ }^{58}$. Outros gestos convencionais eram ainda usados, como apertar as mãos em sinal de juramento ${ }^{59}$, abraçar ou acariciar, para demonstrar afeto ou amizade ${ }^{60}$, ou recuar para expressar o desgosto ou repulsa ${ }^{61}$.

A comédia pautava-se por uma maior liberdade nas marcaçóes cénicas, nos movimentos e nos gestos, e por uma maior verosimilhança com a realidade, embora houvesse também alguns gestos típicos - como o gesto chamado de "ganso", executado através das máos e que simulava o bico de um ganso, usado para indicar que estavam a ser proferidas palavras sem sentido. Era também comum assistir-se, nas comédias, a gestos praticados na tragédia, mas sob a forma de paródia.

Com a evolução dos tempos e com a importância cada vez mais acentuada dos atores, tal como aconteceu com a voz, também os gestos passaram a ser executados de forma mais exagerada e inflacionada, acentuando-se o caráter realista dos mesmos, situação que, segundo Aristóteles (Poética, 26.1461b 29 sqq.), terá levado Minisco ${ }^{62}$ a apelidar o jovem seu contemporâneo, Calípides ${ }^{63}$, de macaco, por considerar o seu estilo exageradamente mimético e semelhante a este animal. O Estagirita (Poética, 26.1461b33-4; 26.1462a1-11) estabelece assim a comparação entre os atores antigos e os do seu tempo,

${ }^{57}$ Nas Traquinias de Sófocles, Héracles é envenenado e sofre, por isso, uma terrível agonia a ponto de náo conseguir controlar os membros, o que faz com que o velho e Hilo tenham de se debater para conseguirem segurá-lo no chão.

${ }_{58}$ Vide Orestes, no início das Euménides de Ésquilo.

${ }^{59}$ Vide Sófocles, Traquinias, 1181 sqq.

${ }^{60}$ Vide Sófocles, Édipo em Colono, quando o herói abraça a filha (vv. 1104-5) e tem o desejo de beijar as mãos e a face de Teseu (vv. 1130-1).

${ }^{61}$ Vide Cassandra, no Agamémnon, 1306, de Ésquilo.

${ }^{62}$ Este ator representou para Ésquilo e ganhou o prémio de melhor ator, em 420 a.C., já ao serviço de Eurípides.

${ }^{63}$ Vencedor das Leneias em 418 a.C. 
afirmando que os primeiros tiravam partido apenas da sua voz, sem recorrerem aos gestos exagerados, típicos dos segundos.

\section{5 - DANÇA}

A par dos gestos, a dança tinha também uma parcela muito importante no conjunto do espetáculo teatral e, por isso, as capacidades do ator clássico passavam também por saber dançar.

A presença deste elemento nas performances teatrais é algo que remonta às origens do teatro, situaçáo comprovada não só porque na base do mesmo estão as danças corais, como também pelo facto de os primeiros poetas gregos - Téspis, Frínico, Pratinas, Quérilo - serem apelidados pelos seus contemporâneos de dançarinos ${ }^{64}$, já que, nos primeiros tempos, o poeta era simultaneamente ator e coreógrafo de si próprio.

Segundo D' Arnott (1989: 56), a dança grega era extremamente mimética, sendo que o principal objetivo não era o de executar um movimento rítmico, mas o de 'imitar' pessoas e atividades de todos os dias. Plutarco (No Banquete, 9.747a-748e) assim o defende quando afirma que aos dançarinos era exigido não apenas que ostentassem posiçóes graciosas como também que representassem determinadas personagens ou emoçóes e, neste seguimento, distingue, na dança, três elementos ou fases - phora (movimento), schema (combinação de passos e atitudes) e deixis (exibição ou demonstração), sendo que este último, no entanto e segundo Capone (1935: 31), não era imitativo porque era um gesto puramente indicativo que náo traduzia qualquer tipo de imagem.

Existiam vários tipos de danças, representativos de uma variedade de temas: a pyrriche, uma dança guerreira; a dança dos Ciclopes; uma dança que representava a marcha dos velhos; o skops ou skopeuma, uma dança que traduzia a procura de algo; o knismos, ao que parece uma espécie de dança exótica, originária da Pérsia; uma dança só de mulheres, que aparentemente traduziria alguma espécie de abandono, muito semelhante ao can-can; o apokinos, supostamente uma dança lasciva e que é mencionada por Cratino e Aristófanes, e ainda outras danças, cujo nome se desconhece ${ }^{65}$, como uma referida por Xenofonte

${ }^{64}$ Vide Ateneu, Deipnosofistas, 1.22a.

${ }^{65}$ Em contrapartida, existem outras danças de que dispomos apenas do nome, sem que saibamos que tipo de movimentos implicavam, tais como a dipodia, o krinon e a igdis. 
(Banquete, 2.15-17), que envolveria a movimentação de todo o corpo. De qualquer forma e no entender de D'Arnott (1989: 56), sobressaem três grandes tipos de danças dramáticas: a emmeleia, uma dança contida, típica da tragédia, o kordax, associado à comédia, e o sikkinis, típico dos dramas satíricos. Obviamente que estas duas últimas eram, convenientemente, mais frenéticas ${ }^{66}$.

Pólux (4.103-5) especifica o schema da dança trágica, distinguindo os seguintes elementos: a máo virada para cima e para baixo, gesto tipicamente assumido para manifestar uma prece; o kalathiskos ou gesto cesta, que consistia em colocar as mãos em forma côncava acima da cabeça; o gesto designado de 'percorrer o tronco', em que as mãos eram colocadas de forma equidistante uma da outra, sendo que depois se movimentavam ao longo do corpo; o 'salto mortal' que, segundo D'Arnott (1989: 58) pode parecer um gesto incongruente aos olhos da modernidade, já que a tragédia é tida como um género solene e dignificante; as 'tenazes', que presumivelmente eram um gesto executado cruzando-se as pernas, e o parabenai tettara, um gesto que continua por esclarecer mas que, na opiniáo de D’Arnott (1989: 58), se significar 'cair de quatro', pode ter sido o realizado pela sacerdotisa de Delfos, no início das Euménides (vv. 34 sqq.) ${ }^{67}$, quando confrontada com a imagem terrífica das Fúrias. Ateneu (Deipnosofistas, 14.629) acrescenta à lista de Pólux outros movimentos ${ }^{68}$, mas não especifica se fazem parte do schema trágico.

De qualquer forma, segundo Capone (1935: 35), a dança, no período clássico, estava subordinada à poesia e à música, sendo que devia acompanhá-las, interpretá-las e traduzir em açóes as palavras, o que é indicativo da existência de alguma liberdade nos movimentos corporais executados na dança.

As partes dançáveis podiam ser executadas pelo coro ou por apenas um ator, tal como acontece com o bêbado Filócleon, que parodia vários estilos de dança, nas Vespas (vv. 1485 sqq.) de Aristófanes, ou com Jocasta, nas Fenícias (vv. 310 sqq.) de Eurípides que, apesar de ser velha, não estaria impedida de

${ }^{66}$ Para mais informaçóes sobre a dança, nomeadamente a pyrriche, vide Carlos Jesus, apud J. R. Ferreira et alii (2009: 403-414).

${ }^{67}$ Vide também a posição de Polimestor, na Hécuba 1056 sqq. de Eurípides.

${ }^{68}$ Uma das danças listadas por Ateneu é a pirueta. 
executar uma dança estática que, para os Gregos, não era mais do que outro modo de expressáo.

\section{6 - ENSAIOS}

Para além de terem de possuir boas capacidades vocais, quer no discurso quer no canto, destreza e harmonia nos movimentos quer gestuais quer de dança, os atores necessitavam também de ser dotados de grande capacidade de resistência. As performances obrigavam-nos a um grande dispêndio de energia e, por isso, os atores eram constantemente preparados para a disciplina. Assim, tinham de se sujeitar a dietas rigorosas, abstendo-se de certos tipos de comida, bebida e até sexo ${ }^{69}$. No entanto, durante os ensaios, os atores tinham condiçôes luxuosas e comiam do bom e do melhor ${ }^{70}$. Plutarco (Sobre a glória dos Atenienses, 349a) dá-nos conta da crítica de um espartano anónimo que refere que os Atenienses procediam mal ao gastarem somas avultadas com o teatro, em vez de disponibilizarem essa quantia para apoio da sua frota e exército.

Uma outra circunstância que implicava grande desgaste físico e uma sobrecarga de calor era, sem dúvida, o uso de máscaras e de um vestuário que, por si só, era extremamente pesado. Acresce ainda o facto de os atores terem de se desdobrar em várias personagens, pelo que o tempo de descanso durante as performances não era muito, e de muito raramente se sentarem, quando estavam em cena ${ }^{71}$; daí que seja considerado um esforço admirável que um ator, Pólo, tenha representado oito tragédias, em quatro dias, com setenta anos de idade.

E exatamente pelo esforço a que estavam sujeitos e pela versatilidade que lhes era exigida, os atores despendiam bastante tempo em ensaios, sendo que o espaço onde os mesmos se desenrolavam era um local privado, longe do olhar dos futuros espectadores. Há razóes para acreditar que os atores decorariam

${ }^{69}$ Plutarco (No Banquete, 737b) dá-nos conta da tradição sobre o ator Teodoro, que estando proibido de dormir com a mulher por causa da proximidade dos festivais, ao voltar a casa vitorioso, foi abraçado pela esposa, numa atitude verdadeiramente trágica, e foi abordado por esta com as seguintes palavras: "Filho de Agamémnon, agora já podes".

${ }^{70}$ Enguias, legumes frescos, carne de bovino, entre outros alimentos.

${ }^{71}$ Uma das poucas exceçôes surge no início do Édipo em Colono de Sófocles, 14 sqq., quando o protagonista, conduzido por Antígona, encontra um local para descansar. 
o texto, ouvindo-o recitado, já que não há indícios de que alguma vez tenham tido acesso ao texto escrito. Esta tarefa da leitura em voz alta era, por vezes, assumida pelo próprio poeta $^{72}$; noutras ocasióes, estaria a cargo de um subordinado, designado de hypoboleus ${ }^{73}$.

\section{7 - Concursos}

O esforço e o tempo dispendidos tinham, no entanto, um grande objetivo - alcançar o primeiro lugar nos concursos honrando, antes de mais, o poeta e a peça, já que inicialmente a competição era apenas entre estes elementos e os coregos, e depois, tendo em vista a sua própria vitória, quando se instituiu o prémio do melhor ator.

Inicialmente, o Estado, na pessoa do arconte, atribuía à sorte os atores a cada um dos poetas, tal como acontecia relativamente aos coregos; mas à medida que a importância dos atores se foi acentuando, de forma a evitar que alguns poetas pudessem beneficiar da participaçáo de um ator mais consagrado do que outro, o Estado determinou que cada um dos protagonistas a concurso no respetivo ano representasse uma das peças da trilogia de cada um dos poetas participantes nos festivais. Quanto ao deuteragonista e ao tritagonista, porque não almejavam alcançar os lugares vencedores ${ }^{74}$, cabia a cada um dos poetas a sua seleção ${ }^{75}$.

A maior parte dos atores da Época Clássica era de origem ateniense e, ao contrário dos elementos do coro que, com a participação ativa nos festivais, cumpriam um dever cívico e religioso, aqueles faziam-no por opção e por ser uma atividade que podia ser exercida por um homem livre sem que este incorresse na infâmia. Segundo Ghiron-Bistagne (1976: 174), a marca mais evidente desta situação decorria do facto de o nome dos atores, na lista de concorrentes e de vencedores dos festivais, não se fazer acompanhar nem de patronímico nem

${ }^{72}$ Plutarco (Sobre a forma correta de escutar, 46b) dá-nos conta de uma situaçáo que pode refletir esta prática: Eurípides a cantar para o seu coro.

${ }^{73}$ Vide Plutarco, Preceitos sobre a forma de conduzir o governo, 813e-f.

${ }^{74}$ Os concursos destinavam-se apenas aos protagonistas. Desconhece-se se o prémio do vencedor era atribuído ao ator que melhor desempenho tivesse no conjunto das peças de uma trilogia, como parece mais razoável, ou se distinguia o melhor em cada uma das performances.

${ }^{75}$ Cf. Taylor (1978: 22). 
de qualquer referência étnica, pelo que se depreende que a arte dramática era um dos poucos domínios onde tinha peso apenas a personalidade e o talento dos artistas. Por essa mesma razão, apesar de a maior parte ser ateniense, havia, no entanto, atores de outras origens ${ }^{76}$, sobretudo na Época Helenística, embora, por exemplo, fosse natural que a associação de Atenas se compusesse maioritariamente de cidadãos atenienses. De qualquer forma, aos olhos dos espectadores, os cidadãos saíam beneficiados ${ }^{77}$.

Um outro fator importante que podia favorecer um determinado ator em detrimento de outro e, por isso, pesar na decisão do júri, era a ordem pela qual os mesmos entravam em cena, já que os Gregos acreditavam que os primeiros beneficiavam de uma maior simpatia por parte dos espectadores. Esta crença era de tal forma sentida, que Aristóteles (Politica, 7.1336b) conta a história de um certo Teodoro que, em vez de optar pelos papéis principais, preferia o que correspondesse à primeira personagem a entrar em cena, ainda que o papel fosse menor. D’Arnott considera que, embora este facto pareça estranho (já que é sabido que Teodoro chegou a desempenhar papéis cuja intervenção não era a inicial), a situação poder-se-á ter verificado, se os textos tivessem sido alterados de forma a satisfazer este capricho do ator. Assim, e embora fosse imprevisível qual seria a primeira peça a ser representada, já que era algo ditado pela sorte, no caso dos atores e ainda que esta situação lhes fosse também extensível, o facto é que, dentro da mesma peça, o encenador tinha liberdade para decidir qual o primeiro ator a entrar em cena e, desta forma, favorecer a sua atuação.

$\mathrm{O}$ protagonista que alcançasse o primeiro lugar ${ }^{78}$ via o seu nome inscrito na lista oficial dos vencedores, a mesma onde constavam os poetas e os coregos vitoriosos, tinha lugar assegurado nas Dionísias do ano seguinte e, de alguma forma, garantia o seu futuro a curto prazo, já que no século V a.C. as solicitaçóes para este tipo de atividade não eram muitas, pelo

${ }^{76}$ Assim o defende Ghiron-Bistagne (1976: 174), que advoga que a expressão usada para definir os membros da associação - hoi technitai hoi en Athenais ("os artistas residentes em Atenas") não excluía os metecos. Já Sifakis (1967: 143) defende que essa mesma associação era composta exclusivamente por cidadãos atenienses.

77 Vide Aristófanes, Aves, 30-36.

${ }^{78} \mathrm{O}$ protagonista que alcançava o primeiro lugar não tinha de ser forçosamente o protagonista da peça vencedora. 
que por esta altura a classe não era nem muito numerosa ${ }^{79}$ nem profissional a tempo inteiro. Quanto à escolha dos outros protagonistas, Rehm (1992: 28) acredita que ela se baseasse em atuaçóes anteriores dos mesmos quer em festivais maiores quer em menores e, quando necessário, em audições perante o arconte epónimo. De qualquer forma, por altura dos festivais, os atores protagonistas eram pagos pelo desempenho do seu trabalho e esse pagamento era feito pelo arconte. Segundo Ghiron-Bistagne (1976: 180), o montante dos salários era fixado por decisáo da Assembleia ${ }^{80}$ e o pagamento era feito da mesma forma em todas as cidades, através de um contrato estabelecido entre o Estado e os atores selecionados para os festivais. No tempo de Aristófanes, o salário dos protagonistas podia chegar aos três óbolos por dia e, no século III a.C., aos nove. ${ }^{81}$. Era o protagonista que pagava aos outros atores, pelo menos ao tritagonista que dependia diretamente da sorte do ator principal. Quanto aos deuteragonistas, Ghiron-Bistagne (1976: 185) acredita que estes atores fossem também eles associados de uma determinada companhia e, por isso, recebessem um salário já estipulado e inferior ao do protagonista, como é o caso de Símilo e Sócrates ${ }^{82}$; daí que, por vezes, os atores tivessem de recorrer a outros expedientes, como viver sobre a proteção de um mecenas ou dar liçóes de dicção a oradores ${ }^{83}$

${ }^{79}$ Para este facto contribuía, por um lado, o reduzido número de atores exigido em cada performance (máximo três atores) e, por outro, a escassez de acontecimentos em que podiam participar. Recorde-se que os grandes festivais dramáticos, em Atenas, decorriam apenas durante três semanas. Segundo D'Arnott (1989: 44), ainda que houvesse outros eventos menores, o certo é que, em grande parte do ano, provavelmente estes homens desempenhariam outras funçôes, como por exemplo ensinar a falar em público.

${ }^{80}$ Vide Aristófanes, Rãs, 367-8.

${ }^{81}$ Para se ter uma noção do quanto os atores ganhavam, nesta altura, um ourives ou um artesáo tinham de trabalhar entre dois e seis meses para ganhar aquilo que um ator trágico arrebatava numa representação. Cf. Ghiron-Bistagne (1976: 184).

${ }^{82}$ Cf. Demóstenes, Sobre a Coroa, 262.

${ }^{83} \mathrm{O}$ exemplo mais famoso desta situação é o de Ésquines. Demóstenes terá aprendido a falar em público com o ator Andronico ou, segundo uma outra versão, com o grande Pólo. Existem também notícias de que terá aprendido a controlar a respiração com Neoptólemo. 
- phonaskia -, situação que fez com que alguns atores, na Época Helenística, fizessem fortuna.

Os atores recebiam ainda outras honrarias, como uma coroa de hera, ao que parece conferida apenas aos vencedores pelo arconte $^{84}$. Na Época Helenística, há relatos que indiciam que, muitas vezes, esta coroa foi substituída por uma de ouro.

\section{8 - EvoluÇấo}

A partir do século IV a.C., a classe profissionalizou-se na sequência da projeção que os atores passaram a ter, em detrimento do coro, que foi relegado para segundo plano. Daqui resultou não só a já falada instituição de prémios $^{85}$ para o melhor ator, como também a própria evolução do edifício teatral que, com a introdução do proscénio $^{86}$, sublinhou a importância destes elementos.

Por esta altura também começaram a surgir pequenas companhias em volta de um determinado ator protagonista. De cada companhia faziam parte, além deste último elemento mencionado, dois atores capazes de interpretar uma variedade de papéis e, provavelmente, um outro elemento, responsável pelo desempenho de personagens mudas. Desta forma, as companhias tinham todas as condiçóes necessárias para corresponder às necessidades do poeta cuja obra lhes fosse destinada representar. De igual modo, neste período são visíveis também famílias de atores, o que revela a existência de um certo caráter hereditário dentro da profissão.

O papel dos atores foi sendo de tal forma preponderante ${ }^{87}$ que se acredita que, nos finais do século IV a.C., reposiçóes de

${ }^{84}$ Plutarco, Sobre se os velhos devem tomar parte na condução do governo, $785 \mathrm{~b}$.

${ }^{85}$ A data dos primeiros concursos de atores trágicos remonta a 449 a.C. Já no que diz respeito aos concursos cómicos, estes terão começado por ocorrer, nas Leneias, cerca do ano 400 a.C. Vide Csapo \& Slater (1994: 222). Segundo Rehm (1992: 27), em 450-49 a.C., o Estado assumiu a responsabilidade do pagamento aos atores, instituindo um prémio para o melhor, nas Grandes Dionísias. Seguiu-se, em 432 a.C., a realização dos concursos trágicos também nas Leneias. Em relação à comédia, e porque os atores só podiam competir num dos géneros, estabeleceu-se a atribuição de prémios, primeiro nas Leneias, no século $V$ a.C., e depois nas Grandes Dionísias, no século IV a.C.

${ }^{86}$ Sobre as alterações do edifício teatral, vide cap. 2.

${ }^{87}$ Aristóteles, (Retórica, 3.1403b31-35), lamenta que o teatro, que em tempos pertenceu aos poetas, pertencesse, nos dias dele, aos atores. 
Ésquilo, Sófocles e Eurípides tenham sido bastante adulteradas com o objetivo de serem destacadas as intervençôes dos atores, havendo inclusivamente indícios de que muitas delas possam ter sido apresentadas sem coro. Por esta razão, Licurgo, em 330 a.C., promulgou uma lei que estabelecia que as peças dos três grandes tragediógrafos fossem representadas na íntegra e que os textos originais fossem respeitados, em qualquer um dos locais responsáveis pela organização dos concursos dramáticos ${ }^{88}$.

No decorrer da Época Helenística, os privilégios dos atores foram aumentando, sendo que, por exemplo, passaram a estar dispensados do serviço militar, a ter garantias de livre-trânsito ${ }^{89}$ de cidade em cidade e a estar isentos do pagamento de impostos ${ }^{90}$. Csapo \& Slater (1995: 40) acrescentam ainda que passaram a ter o direito de usar coroas e de se vestirem de púrpura e ouro; e, de tal forma começaram a ser caprichosos, que D’Arnott (1989: 84) chega mesmo a considerá-los verdadeiras prime donne.

No entanto, também por esta altura, a reputação dos atores começou a degradar-se, sendo que até os censores políticos começaram a colocar em causa a lealdade dos mesmos. Platão, Demóstenes e Aristóteles não tiveram pejo em demonstrar a sua antipatia por estes elementos, acusando-os, entre outras coisas, de serem gente depravada ${ }^{91}$.

A este respeito, Duncan (2006: 91) defende que a personagem do alazon na comédia representa a perceção que o mundo grego tinha dos atores, já que, por esta altura, os mesmos aspiravam alcançar uma posição elevada na sociedade grega e passaram a ser catalogados de gananciosos e arrogantes. Esta arrogância é alvo de ridicularização pela tradição, que nos dá conta de histórias ${ }^{92}$ como a do ator Calípides que, julgando ser facilmente reconhecido pelo rei espartano Agesilau, foi apelidado de palhaço.

Apesar de serem fruto da democracia, com o passar do tempo, os atores passaram a ser apadrinhados pelas monarquias

${ }^{88}$ Vide Pseudo-Plutarco, Vida dos Dez Oradores, 841.

${ }^{89}$ Cf. Duncan (2006: 122).

${ }^{90}$ De qualquer forma, não chegariam a ser convidados para o banquete de homenagem nem do corego vencedor nem do poeta. Vide Platão, Banquete, 194a-b.

${ }^{91}$ Vide Aristóteles, Problemas, 956b11-12.

92 E.g. Plutarco, Vida de Agesilau, 21. 
e a viver majestosamente sob a sua alçada. Assim aconteceu com os protegidos de Alexandre-o-Grande, que passaram por isso a deter o epíteto de aduladores de Alexandre ${ }^{93}$. Outros fizeram fortunas consideráveis e outros ainda enveredaram por carreiras políticas, tornando-se embaixadores proeminentes.

${ }^{93}$ A piada resulta do facto de a partir de determinada altura se ter passado a apelidar os atores de aduladores de Diónisos (dionysokolakes). Vide Ateneu, Deipnosofistas, 12.539; Aristóteles, Retórica, 3.1405a20-4. 


$$
\text { 6 - Coro }
$$


(Página deixada propositadamente em branco) 


\section{1 - Participação}

Desde as origens do teatro até à Época Helenística, o papel do coro nas performances foi sofrendo alteraçóes, de tal forma que passou, em menos de dois séculos, de elemento primordial da ação dramática a mero acessório, destinado mais a entreter o público do que propriamente a contribuir para o desenrolar da ação ${ }^{1}$.

Assim, antes ainda da instituição do teatro, o papel do coro era extremamente relevante, porquanto era ele o responsável pelos ditirambos, os quais estarão possivelmente na origem da própria arte de representação. Estes coros, um de homens, outro de rapazes, num total de vinte, eram constituídos por cinquenta elementos, selecionados de entre as dez tribos atenienses e, por isso, representavam cada uma delas. Desconhecem-se os critérios que presidiam a esta seleção, mas sabe-se que apenas os cidadãos ${ }^{2}$ eram alvo de escolha por parte do corego ${ }^{3} \mathrm{e}$ que a sua participação era um dever cívico e religioso. Por esta razão, não lhes era atribuído nenhum salário, mas acredita-se que lhes fosse paga, na pessoa do corego ${ }^{4}$, uma espécie de indemnização pelos dias dedicados aos ensaios e à participação nos festivais ${ }^{5}$. O corego suportava ainda todos os gastos inerentes ao ensaio dos coros, ao cenário, aos figurinos e, inclusivamente, ao banquete que oferecia ao poeta, em caso de vitória, sendo que, por isso, a escolha desta figura recaía sobre um cidadão

${ }^{1}$ Wiles (1997: 77) refere que, neste período mais recente, a esfera da razáo e da moralidade pertencia aos atores, enquanto ao coro sobejava a expressão física.

2 Segundo Csapo \& Slater (1994: 352), o facto de a iconografia ática, de que é exemplo o vaso Prónomo (cf. supra cap. 3, n. 34), geralmente representar os coreutas como sendo jovens e imberbes, normalmente o símbolo da adolescência, deu recentemente azo à teoria de que os coros eram compostos por epheboi, jovens submetidos a treinos militares; mas, do ponto de vista dos estudiosos, as fontes não suportam a interpretação de que a participação em coros fosse um dever oficial dos epheboi.

${ }^{3}$ Cada poeta que pretendesse concorrer aos festivais solicitava um coro ao arconte, sendo que o mesmo lhe era atribuído, mas somente no caso de o poeta ser selecionado para participar nos concursos.

${ }^{4}$ Há ainda relatos que dão conta da forma como, depois das performances, alguns coreutas eram protegidos, bem tratados e bem alimentados pelo corego, razáo que levou Wilson (1997: 95) a considerar que a relaçáo entre corego e coreutas era mais pessoal que outras relaçóes que envolviam pagamentos.

${ }^{5}$ Cf. Ghiron-Bistagne (1976: 179); Rehm (1992: 25). 
rico que, no desempenho desta função, poderia pagar os seus impostos ${ }^{6}$, já que, segundo Zimmermann (1991: 10), a coregia era uma forma de tributação indireta, as denominadas liturgias ou deveres públicos, a que os ricos estavam sujeitos. Para as Grandes Dionísias, eram necessários vinte e oito coregos - vinte para os ditirambos, um por cada um dos três poetas trágicos a concurso e um por cada um dos cinco cómicos.

Em relação à tragédia, e ao contrário do que acontecia com os ditirambos, os coros não tinham qualquer representatividade tribal e, inicialmente, eram compostos por doze elementos ${ }^{7}$, tendo passado depois a quinze, com Sófocles ${ }^{8}$, número que náo mais se alterou ${ }^{9}$, ainda que as personagens que o coro representava pudessem ter um número diferente do de coreutas, como acontece, por exemplo, nas Suplicantes de Ésquilo (v. 321$)^{10}$, que o poeta caracteriza como sendo cinquenta, ou

${ }^{6}$ Para mais informaçôes sobre a coregia, vide cap. 1, 20-22.

7 Um dos passos mais advogados para justificar esta situação, por exemplo por Csapo \& Slater (1994: 353), é o facto de, no Agamémnon de Ésquilo, depois da morte do rei, os elementos do coro intervirem individualmente, sendo que, realmente, o texto parece poder dividir-se em doze partes, cabendo cada uma delas a um dos elementos. Este passo é também um exemplo de que, esporadicamente, a coletividade do coro se podia transformar em individualidade. Há, no entanto, quem defenda também, como Haigh (1907: 289), que o coro no Agamémnon seria constituído por quinze elementos, tendo em conta náo só este passo como os três versos que o antecedem; mas Pickard-Cambridge (1953: 242) é de opiniáo que os três versos em causa terão sido proferidos pelo corifeu. Wiles (2000: 133) advoga que o número doze significava um completo círculo cósmico e, por isso, o estudioso acredita que, nesta altura, a futura função do corifeu pertencia ainda ao ator principal.

${ }^{8}$ Vide Vida de Sófocles, 4; Suda, s.v. Sophokles. Rehm (1992: 25) acredita que efetivamente a inovação se tenha devido a um dos três grandes tragediógrafos e, embora se desconheça a data e a razão que esteve na base da alteração, ela possa ter decorrido do desejo de fazer representar um maior número de cidadãos nas produçôes trágicas.

${ }^{9}$ Haigh (1907: 290) acredita no entanto que, depois de os coros dramáticos terem sido reduzidos à insignificância, tendo ficado responsáveis apenas pelos interlúdios musicais, o número de elementos tenha também diminuído, pelo menos em alguns teatros, já que, por exemplo, os coros cómicos nas Sotérias de Delfos eram constituídos somente por sete elementos. Vide Lista de Vencedores das Sotérias ( $\left.S I G^{3} 424 \mathrm{~A}\right)$.

${ }^{10}$ Harsh (1944: 17) acredita que, neste caso concreto, o coro era mesmo constituído por cinquenta elementos, mas Pickard-Cambridge (1953: 241) defende que este ponto de vista é o resultado de uma provável confusão, decorrente do facto de, por um lado, a tragédia derivar dos 
na tragédia homónima de Eurípides (v. 100), onde são descritas como sete. Quinze era também o número de elementos que compunham os coros dos dramas satíricos ${ }^{11}$. Quanto à comédia, eram necessários vinte e quatro coreutas ${ }^{12}$, os quais, segundo sustenta Wiles (2000: 135), seriam provenientes de duas tribos, doze de cada, de forma a que, no conjunto das comédias a concurso (cinco), todas as tribos fossem representadas. Acredita-se também que, inicialmente, esta fosse uma função desempenhada de forma voluntária, sem qualquer compensação, dado que, só muito mais tarde do que aconteceu em relação à tragédia, o Estado assumiu também os encargos desta competição.

\section{2 - EvoluÇáo}

Quando, segundo a tradição, Téspis se distanciou do coro e deu origem ao primeiro ator, aquele continuou a deter um papel preponderante face a este, situação que se manteve mesmo com a introdução do segundo e terceiro atores por Ésquilo ${ }^{13}$ e Sófocles, ainda que no caso deste último tragediógrafo a participação do coro fosse já mais diminuta. É com Eurípides que a figura do coro começa a perder a sua relevância ${ }^{14}$, já que é notório que este lhe confere um papel menor, parecendo,

coros ditirâmbicos, compostos por cinquenta elementos, e, por outro, de a tradição atribuir a Dânao cinquenta filhas. Acresce ainda o facto de existir um relato, improvável, por parte de Pólux, de que os coros deixaram de ser constituídos por cinquenta elementos depois de a entrada em cena das Fúrias, nas Euménides de Ésquilo, ter causado tanto pânico na audiência.

${ }^{11}$ Exemplo disso parece ser o vaso Prónomo (supra cap. 3, n. 34). Cf. Csapo \& Slater (1994: 69-70); Wiles (2000: 130).

${ }^{12}$ Vide Aristófanes, Aves, 296 sqq. Aristóteles (Politica, 1276b1-9) sugere que os coros trágicos e cómicos eram compostos pelos mesmos cidadãos.

${ }^{13}$ No entanto, nas últimas peças deste tragediógrafo, é visível uma maior semelhança do papel do coro com o que lhe é conferido por Sófocles e Eurípides, uma vez que o mesmo acabou também por ser relegado para segundo plano, surgindo não como participante na ação, mas apenas como empenhada testemunha, que seguia atentamente os diálogos, retirando depois ilações morais.

${ }^{14}$ Haigh (1907: 285) defende que, na maior parte das peças esquilianas, o coro intervinha em cerca de $50 \%$ de toda a composição; em Sófocles, variava entre um quarto, no Ájax e na Antígona, e um sétimo, na Electra e no Filoctetes; em Eurípides, entre um quarto, nas Bacantes e na Alceste, e um nono, por exemplo, no Orestes. A diminuição das intervençôes do coro foi acompanhada também pela diminuição da sua importância. $\mathrm{Na}$ mesma esteira, Csapo \& Slater (1994: 349) defendem que, nas últimas 
inclusivamente, haver indícios de que, se pudesse ${ }^{15}$, o tragediógrafo talvez tivesse abdicado dele ${ }^{16}$. Assim, e como poeta realista que é, o coro era para Eurípides um estorvo e, por isso, na maioria das suas peças, o tragediógrafo optou por uma de duas situaçóes: ou elevá-lo à categoria de personagem, sem a qual a ação não se desenrolaria, tal como é visível na Medeia, na Hécuba ou no Íon, ou reduzir o seu papel quase à nulidade, como acontece, por exemplo, no Hipólito ou na Ifigénia em Aulide. Nesta última tragédia é, aliás, evidente a existência de um interlúdio lírico (vv. 1036-1097) que, embora permita criar suspense antes do grande clímax, não apresenta uma relação direta com o desenvolvimento da ação. Na sua última produção, As Bacantes, e ainda que o coro tenha ocupado o espaço que lhe era habitual nos primeiros tempos do teatro, na opinião de Zimmermann (1991: 24), longe de moldar ativamente os acontecimentos do jogo, o coro funciona mais como pano de fundo contra o qual esses eventos são projetados.

Assim, e na perspetiva deste autor (Zimmermann 1991: 24-5), em geral, o coro de Eurípides não tinha uma participação ativa nas tragédias, sendo que, inclusivamente, quer o interesse por si demonstrado em relação aos factos retratados na ação quer do público em relação a si mesmo passou a ser muito diminuto, tendo-lhe ficado reservado, apenas, o canto de odes de caráter mitológico, nas pausas entre os diálogos, cujo conteúdo não contribuía diretamente para o desenrolar dos acontecimentos vividos no enredo, ao contrário do que acontecia em Ésquilo, cujo coro era o veículo da ação dramática, e, em Sófocles, onde, apesar de lhe ser conferido um papel menor, se mantinha como uma persona dramatica distinta.

De qualquer forma, é na viragem do século $\mathrm{V}$ para o IV a.C., nomeadamente com a figura de Ágaton ${ }^{17}$, que se assiste de uma forma mais evidente ao relegar do papel do coro para

peças de Eurípides, os seus comentários e mesmo a sua presença eram muitas vezes ignorados pelas outras personagens.

${ }^{15} \mathrm{O}$ impedimento resultava do facto de a organização dos festivais apresentar como obrigatória a participação dos coros.

${ }^{16}$ Segundo D’Arnott (1989: 37), há indicaçóes de que alguns dos seus trabalhos foram dados a conhecer, primeiramente, em espetáculos privados, fora do contexto dos festivais, e que, nesses casos, o tragediógrafo ter-se-ia servido de um número mínimo de coreutas ou até mesmo de nenhum.

${ }^{17}$ Vide Aristóteles, Poética, 18.1456a29-30. 
segundo plano $^{18}$, já que, por esta altura, o enfoque passou a ser atribuído aos atores, sendo que a participaçáo do coro passou a ser escassa, cabendo-lhe quase exclusivamente a intervenção em interlúdios ${ }^{19}$ - embolima - entre as peças, que mais não eram do que cânticos com pouca ou sem qualquer relaçáo com os acontecimentos representados no espaço cénico, passando, desta forma e definitivamente, a estar afastado da ação dramática. Para esta situação, para além da preponderância do papel dos atores, terá contribuído também a separação física entre estes, uma vez que, a partir do século IV a. C., e como já referido anteriormente, os atores passaram a atuar num plano superior diante da skene e o coro manteve-se confinado à orchestra, o que, na opinião de Centanni (1995: 126), terá tido implicações na assunção, por parte deste último, de uma atitude passiva em relação à ação cénica. É também por esta altura que se assiste, na representação de peças antigas, à deturpação dos textos originais, nomeadamente no que concerne ao papel do coro, o qual foi, muitas vezes, totalmente omitido. Acresce ainda o facto de, neste período, ser constrangedora a diferença existente entre o profissionalismo dos atores e o amadorismo do coro, cujos elementos continuavam a ser selecionados de entre os cidadáos, pelo menos até à abolição da coregia, no final do século IV a.C., altura em que aparecem registos de coros profissionais nas inscriçóes dos festivais.

Depois do século IV a.C., e segundo Haigh (1907: 287), muito pouco se sabe sobre a história do coro, mas as evidências parecem apontar para a sua total ausência, na tragédia, já durante o século III a.C., situação que com o passar do tempo se veio cada vez mais a acentuar.

Na comédia assistiu-se à mesma perda de importância do papel do coro, pelo que é notório que, a partir das Mulheres na Assembleia, estreada em 392 a.C., Aristófanes tende a diminuir as suas intervençóes ${ }^{20} \mathrm{e}$, apesar de a sua ainda participação na

${ }^{18}$ Esta tendência acentuar-se-á ainda mais na Época Helenística.

${ }^{19}$ Aristóteles, que viveu num tempo em que esta prática se tinha generalizado, condenava duramente esta situação, sugerindo que o coro tivesse o mesmo estatuto que os atores e que, por isso, interviesse de forma incisiva na ação. Vide Aristóteles, Poética, 18.1456a26sqq. Cf. Aristóteles, Problemas, 19.922b10-27.

${ }^{20}$ Segundo Csapo \& Slater (1994: 349), na primeira comédia de Aristófanes, os Acarnenses (425 a.C.), a percentagem da participação do coro ascende aos 24\%, ao passo que, no Pluto (388 a.C.), náo passa de $3.2 \%$. 
Comédia de Transição e Nova, ela restringia-se apenas aos interlúdios. Nos finais do século IV a.C., começam a existir cada vez menos vestígios da sua presença nas performances e, em meados do século III a.C., há, inclusivamente, registos de coros cómicos, como nas Sotérias de Delfos, constituídos por oito ou sete elementos ${ }^{21}$.

\section{3 - Ensaios}

Nos primeiros tempos, eram os próprios poetas que ensaiavam os seus $\operatorname{coros}^{22}$. Frínico e Ésquilo ficaram famosos pelo desempenho desta tarefa e Sófocles é tido, pela tradição, como um grande ensaiador de $\operatorname{coros}^{23}$. Depois, e a partir do final do século $\mathrm{V}$ a.C. ${ }^{24}$, assistiu-se à profissionalização dos diretores de coros - chorodidaskaloi -, mais exactamente por volta de 412, altura em que se acredita que o Estado, assumindo todas as despesas inerentes aos encargos previstos para esta função, atribuísse a cada corego um chorodidaskalos, que, segundo Capone (1935: 27), instruía o coro, organizava a representação, tratava da cenografia, distribuía as partes e dirigia a interpretação dramática. Acredita-se que, tal como com os atores, o ensaio dos coros não ocorresse no recinto destinado aos festivais, já que, atraindo curiosos, todo o efeito surpresa nos concursos se perderia. A atestá-lo está um passo de Antifonte (Sobre o coreuta, 11), onde o diretor de um coro de rapazes para as Targélias (um festival de caráter não dramático) refere que converteu um dos quartos de sua casa em sala de ensaios, tal como havia feito quando fora corego nas Dionísias.

Como a escolha do corego decorria no verão, isso significava que todos os elementos envolvidos na performance tinham cerca de oito meses para ensaiar. No caso do coro trágico, as exigências de ensaios eram maiores do que para qualquer um dos outros intervenientes, porquanto aquele tinha de atuar em quatro peças diferentes ${ }^{25}$, o que pressupunha inúmeros e variados movimentos, danças e cânticos, os quais tinham que

${ }^{21}$ Vide Lista de Vencedores das Sotérias $\left(S I G^{3} 424 \mathrm{~A}\right)$.

${ }^{22}$ Vide Plutarco, Sobre a forma correta de escutar, 46b.

${ }^{23}$ Cf. Pickard-Cambridge (1953: 91-92).

${ }^{24}$ Cf. Demóstenes, Contra Midias, 14-18.

${ }^{25}$ Cada coro representava um poeta, que competia nos festivais com uma trilogia e um drama satírico. Segundo Wiles (2000: 128), no final da representação do drama satírico, o coro, liberto de um longo período 
ser executados, as mais das vezes, em uníssono ${ }^{26}$, de acordo com a coletividade que lhe era inerente.

Já na comédia, o período destinado aos ensaios não necessitava de ser tão extenso, porquanto os seus intervenientes atuavam em apenas uma composição.

\section{4 - FunÇốES}

Independentemente da evolução verificada no que respeita ao papel do coro, o facto é que a pertinência da sua presença ao longo dos anos, de uma forma mais ou menos acentuada, é inquestionável, porquanto muitas são as funçôes que se lhe podem atribuir. Uma das mais importantes é, sem dúvida, a de narrador, função que o coro, desde os primórdios da sua existência, sempre foi desempenhando, nessa fase duma forma ainda mais incisiva, porquanto os ditirambos não eram mais do que narraçóes cantadas de acontecimentos. Assim, à luz da nomenclatura moderna, poder-se-á dizer que ocasióes houve em que o coro foi um narrador omnisciente, que demonstrava saber mais do que o comum dos espectadores, pelos indícios que frequentemente ia fornecendo, sob a forma de prolepses ${ }^{27}$; outras, em que sabia tanto como o público, e outras ainda em que revelava ter um conhecimento menor do que a audiência, na medida em que vaticinava situaçóes que náo se vinham depois a comprovar com o desenrolar da peça ${ }^{28}$. Esta ausência de conhecimento sobre o desenrolar intrínseco da ação, evidente em bastantes peças, levou a que muitos estudiosos atribuíssem ao coro o epíteto de "espectador ideal”, já que este reagia, muitas vezes, aos acontecimentos dramáticos como se eles constituíssem novidade e, por isso, como se os coreutas soubessem tanto como o comum dos espectadores, e porque comummente reinterpretavam a mensagem veiculada na peça conferindo-lhe um estatuto universal - objetivo último que os poetas perseguiam. Um desses estudiosos é Zimmermann

de ensaios e da prestaçáo oficial nos festivais, bebia vinho copiosamente para celebrar a sua participação e regressava à vida de todos os dias.

${ }^{26}$ Wiles (2000: 132) defende que a uniformidade exigida aos coros só era possível porque os jovens que os constituíam praticavam, desde tenra idade, danças corais e cânticos no contexto de diferentes festivais religiosos.

${ }^{27}$ É o que acontece, por exemplo, no Agamémnon de Ésquilo (vv. 5559) quando o coro, no párodo, afirma que a ira não esquecerá a vingança de uma filha e cairá sobre o rei argivo.

${ }^{28}$ Vide Ésquilo, Coéforas, 931 sqq.; Eurípides, Medeia, 282 sqq. 
(1991: 21) que lhe confere esta função, ao defender que o coro devia ser entendido como a personificação de uma meditação sobre a ação da peça, a encarnação do poeta como voz da humanidade, a figura que atenuava os acontecimentos chocantes da ação, evidenciando, através da música, as próprias emoçóes da audiência e conduzindo-a ao domínio contemplativo. De igual forma, Rehm (1992: 60-61) ${ }^{29}$ atribui-lhe o mesmo papel, ao conceber que o coro era livre para apoiar, ignorar, questionar ou rejeitar as atitudes das personagens centrais. Acresce ainda o facto de, enquanto espectador ideal, o coro cumprir também a função catártica da tragédia, como é visível, por exemplo, quando, ao perscrutar as palavras agoirentas de Cassandra, no Agamémnon de Ésquilo, e ao apiedar-se da personagem, afirma: "O teu destino cruel fere-me como uma mordedura mortal, quando te ouço gritar as notas lamentosas que me partem o coração" (vv. 1164-66) ${ }^{30}$.

O coro era também um intermediário entre o mundo ficcional da peça e a realidade da audiência, já que por natureza, composição e colocação física, pertencia simultaneamente ao mundo da peça e ao mundo da audiência ${ }^{31}$ e, por isso, são muitas as situaçóes em que, como mediador entre estes dois mundos, nos deparamos com o coro a relatar e a relembrar à audiência acontecimentos vários. Além disso, funcionava como veículo para a universalização da história, já que, enquanto comentador, transcendia regularmente os limites da sua caracterização, estabelecendo a relação entre a ação em concreto, que os espectadores presenciavam, e um sem número de outras histórias e situaçóes ocorridas noutras épocas e noutros contextos, de forma a evidenciar a atemporalidade dos princípios defendidos e dos temas retratados. É neste sentido que Zimmermann (1991: 21) advoga que vê no coro não a individualidade, mas um conceito geral, representado materialmente e cuja presença corporal afetava profundamente os sentidos. Assim, este mesmo coro, variadas vezes, abandonava a ação central para meditar no passado e no futuro, em tempos e povos distantes, na própria humanidade, de forma a concluir grandes verdades

${ }^{29}$ Para além de espectador ideal, Rehm afirma ainda que o coro representava a cidade, o comum dos homens e das mulheres, a visão do século $\mathrm{V}$ a.C., por oposição ao ethos arcaico dos heróis retratados.

30 Tradução de Manuel de Oliveira Pulquério (Lisboa, Edições 70, 1998).

31 Vide Wiles (1997: 123). 
sobre a experiência humana e a transmitir grandes liçóes de sabedoria. Da mesma opiniáo partilha Calame (2005: 216), que define o coro como um conceito geral, empiricamente representado por uma multidão poderosa e que se fazia sentir ${ }^{32}$. A função do coro trágico, enquanto entidade real e ideal, seria a de acompanhar e comentar a ação dramática e daí extrair liçôes de universal importância.

Outra das funçôes do coro, na opinião de Harsh (1944: 21), era a de servir de interlocutor do ator, nomeadamente no que concerne ao corifeu, já que, obviamente, resultava num melhor efeito dramático para o ator dirigir um discurso informativo diretamente ao coro em vez de à audiência, até porque, principalmente na tragédia, os apartes rareavam ${ }^{33}$.

Muitas vezes, o coro era também a voz da consciência, porquanto, frequentemente, tecia juízos de valor, tornando-se numa espécie de voz da Moira, que ataca todos aqueles que são insolentes ${ }^{34}$, sendo que, por vezes, o coro agia de acordo com a sua perspetiva pessoal, como acontece nas Bacantes de Eurípides, e, outras vezes, assumia uma voz política e social, em concordância com a ideologia do poeta, como se constata ter acontecido relativamente ao famoso coro da Necessidade na Alceste de Eurípides (vv. 962-983), cujo discurso era nitidamente o do poeta e não o dos velhos anciãos de Tessália. De qualquer forma, é difícil avaliar quando é que o coro agia de acordo com uma ou a outra forma.

Os coros ajudariam também a identificar as novas figuras que entravam em cena ou a que estava a fazer uso da palavra, através da apresentação da personagem e do olhar direcionado para a mesma. A ele competia também, variadas vezes, a caracterização de personagens e o comando ou a antecipação da ação, como acontece, por exemplo, ao longo do quarto episódio do Agamémnon de Ésquilo (vv. 1072-1342), já que é através das questôes que o coro vai colocando a Cassandra que é possível ao espectador ter conhecimento dos antecedentes desta mulher,

${ }^{32}$ A importância da coletividade do coro refletia-se também no efeito em grande escala que este podia proporcionar, não só em termos visuais como vocais.

${ }^{33}$ Um dos poucos está presente na Hécuba, 736-51, de Eurípides.

${ }^{34}$ Exemplo disso é o que acontece no primeiro estásimo do Agamémnon de Ésquilo (vv. 385-402), quando Páris é comparado a todo e qualquer homem que incorreu em culpa e que, por isso mesmo, é ignorado pelos deuses. 
nomeadamente no que diz respeito às suas profecias e à forma como estas são interpretadas pelos cidadãos comuns.

Por vezes, era também o veículo de transmissão de acontecimentos decorridos nos bastidores, como acontece nas Bacantes de Eurípides (vv. 862 sqq.), quando, depois de Penteu ter sido conduzido por Diónisos ao monte Citéron, o coro relata à audiência como Agave o descobriu e o confundiu com um leão.

$\mathrm{O}$ coro desempenhava também a função de representar um grupo específico e, nesse sentido, um conjunto de personagens - como por exemplo, de velhos, no Agamémnon e nos Persas de Ésquilo, de mulheres estrangeiras, nas Suplicantes, ou de Fúrias, nas Euménides do mesmo tragediógrafo - sendo que, às vezes, as personagens por si representadas constituíam as figuras centrais da ação, como acontece nas Suplicantes quer de Ésquilo quer de Eurípides, ainda que, na opinião de Harsh (1944: 21), a sua ação tendesse a ser mais passiva do que ativa, o que não impedia, na visão de Wiles (2000: 142), que o coro se envolvesse na ação, aconselhando as personagens ou sendo seu cúmplice no silêncio. De qualquer forma, a relação do coro com a ação era bastante flexível, sendo que podia variar, de acordo com as necessidades intrínsecas à peça ${ }^{35}$ e, por isso mesmo, já nas Euménides de Ésquilo o seu papel é extremamente ativo.

Belessort (1934: 33-34) define ainda o coro como a testemunha, o confidente, o que se associa à dor, o conselheiro, o juiz, o intérprete lírico do poeta, o eco do senso popular e aquele que nos adverte para o facto de as personagens da peça não se moverem no mesmo plano que nós, mas num plano que é um legado da religião, já que o coro é um sobrevivente do culto de Diónisos.

Também Horácio, na Arte Poética (vv. 193-201), ao comentar o estatuto conferido ao coro no seu tempo, demonstra de uma forma exímia aquelas que terão sido as grandes funçôes e características dos coros gregos: "Que o coro defenda a sua individualidade recitando o seu papel como um ator, e não cante, no meio dos atos, o que náo se relacionar nem se adaptar intimamente ao argumento. Que ele seja propício aos bons e, com palavras amigas, os aconselhe, aos irados insuflando calma e aos que temem pecar, concedendo amor. Que louve as iguarias da mesa frugal e assim também a justiça saneadora e as leis, tal como a paz que se goza de porta aberta. Que náo

${ }^{35}$ Cf. D’Arnott (1989: 28). 
revele os segredos confiados e peça aos deuses e lhes suplique que a Fortuna volte aos desgraçados e abandone os soberbos" ${ }^{36}$.

Outra das funçóes do coro consistia em personificar a sabedoria coletiva da comunidade, já que frequentemente aludia nas suas odes a um corpus mitológico familiar aos espectadores. Era também o coro que 'emprestava' ao espetáculo a sua componente musical.

\section{5 - Voz}

Nas intervençôes do coro, que se pautavam também tal como os atores pelo uso dos três modos de elocução, predominavam as partes cantadas, visivelmente influenciadas pelos ditirambos, até porque o papel da música era, nos primeiros tempos, de tal maneira relevante, que Aristóteles (Poética, 12.1452b19-22) define as partes constitutivas da tragédia de acordo com as intervençôes cantadas do coro. Assim, e de acordo com o Estagirita, o prólogo é a parte da tragédia que precede a entrada do coro, os episódios, as partes entre as músicas corais e o êxodo, a parte que se segue à última intervenção coral. Daqui se constata que as partes cantadas ocorriam, sobretudo, entre os episódios, nos estásimos ${ }^{37}$, sob a forma de odes corais que, na maior parte das vezes, eram compostas por estrofes - voltas - e antístrofes - contra-voltas ${ }^{38}$.

Segundo Rhem (1992: 53), nesta estrutura, o esquema métrico de uma estrofe era repetido na antístrofe seguinte, depois um esquema métrico diferente era introduzido numa nova estrofe e respetiva antístrofe e assim sucessivamente, obtendo-se a configuração $a-a^{\prime} / b-b^{\prime} / c-c^{\prime}$. Por vezes, entre a estrofe e a antístrofe, surgia uma passagem independente, designada de mesodos (mesodo), que significava, literalmente, 'cântico do meio' e que marcava um ritmo diferente em relação à estrofe $\mathrm{e}$ antístrofe ( $\mathrm{a}-$ mesodo $1-\mathrm{a}^{\prime} / \mathrm{b}-$ mesodo $\left.2-\mathrm{b}^{\prime}\right)$. A finalizar a intervenção do coro, ocasionalmente, o poeta servia-se de uma epode (epodo), que significava, à letra, 'depois do cântico'

36 Tradução de R. M. Rosado Fernandes (Lisboa, Editorial Inquérito, 1984).

$37 \mathrm{O}$ nome atribuído a estas partes não pretendia significar que, enquanto o coro cantava, assumia uma postura estática, mas antes que o coro estava já na orquestra, quando o fazia, na sua posição habitual - stasis.

${ }^{38}$ Há situaçóes em que as odes não tinham responso, pelo que se designavam por astróficas. 
e cujo esquema métrico não correspondia a nenhum dos usados nos pares estróficos.

Estas odes corais não proporcionavam simplesmente momentos reflexivos, mas funcionavam como partes integrantes e correlacionadas com a ação, porquanto, as mais das vezes, retomavam os assuntos retratados nos episódios, acrescentando-lhes outros pormenores, refletindo sobre eles e antecipando circunstâncias ou figuras relevantes para o desenrolar da ação. Além disso, ajudavam a reforçar a mensagem veiculada e a ação ocorrida nos episódios, ainda que D’Arnott (1989: 27) defenda que elas não acrescentavam, no entanto, nada de novo à ação ou, se acrescentassem, essa informação seria repetida novamente, até porque é impossível precisar até que ponto a audiência acompanharia toda a mensagem difundida pelos cânticos. Por outro lado, na visão de Harsh (1944: 18-19), os cantos líricos podiam propiciar uma atmosfera trágica, como acontece no Agamémnon de Ésquilo, ou possibilitar uma pausa de índole poética na turbulência das emoçóes vividas na ação. De qualquer forma, o seu conteúdo estaria sempre diretamente relacionado com o contexto dramático, já que, variadas vezes, generalizavam os acontecimentos particularmente apresentados e interpretavam a ação como o próprio tragediógrafo o teria feito; daí que, também por ser o emissor destas odes, fosse atribuído ao coro o epíteto de espectador ideal. Exemplo disso é o que acontece no final do Rei Édipo de Sófocles (vv. 15241531), quando o coro relembra que nenhum homem se pode considerar feliz até terem terminado os seus dias, enfatizando a ironia do destino, talvez o tema central da peça.

Segundo Calame (2005: 222), porque uma das características essenciais da ação trágica consistia num conjunto de viragens, o sentimento que as odes corais mais frequentemente transmitiam era o de dor psicológica e, assim, a expressão de luto podia geralmente decorrer de diferentes formas ritualizadas de cânticos de lamento, que evidenciavam sobretudo sentimentos de terror, piedade, aflição e misericórdia. Desta forma, a notícia de uma morte violenta ou o confronto com personagens já cadáveres, geralmente, despoletava um canto de lamento ${ }^{39}$, a threnodia, ou

${ }^{39}$ Outras vezes, a morte despoletava um canto de regozijo, tal como se vislumbra, nas Coéforas de Ésquilo (vv. 935-971), em relação a Egisto. 
mais genericamente um $k_{0 m m o s^{40}}$, que literalmente significava 'bater com as máos no peito' em sinal de luto e que ocorria exatamente para sublinhar este tipo de situação, como é visível depois da morte de Agamémnon na peça homónima de Ésquilo (vv. 1448-1496), ou depois da morte de Jocasta e da cegueira de Édipo, no Rei Édipo de Sófocles (vv. 1186-1223). Também no Édipo em Colono de Sófocles, e na opiniáo de Dale (1965: 21), a primeira confrontação de Édipo com o coro é tão carregada de emoçóes - como raiva, medo, terror e piedade - que se torna impreterível o recurso ao kommos. Segundo Murnaghan (2005: 248-249), este tipo de canto estava muito relacionado com as mulheres, sendo que são muitas as tragédias que contêm um amplo número de lamentos, nos quais a expressão de perda das personagens femininas levanta questóes profundas e difíceis ou precipita novas catástrofes, como acontece nas Coéforas de Ésquilo (vv. 84 sqq.), quando o coro e Electra partilham um longo kommos sobre o túmulo de Agamémnon que ajuda a desencadear a vingança de Orestes sobre Clitemnestra; ou então no Agamémnon do mesmo tragediógrafo (vv. 1071 sqq.), quando Cassandra se serve de um cântico de lamento para evocar toda a sequência passada e futura da casa de Atreu, incluindo a sua eminente morte às mãos de Clitemnestra.

São ainda visíveis nas peças trágicas exemplos de diálogos cantados ou cânticos alternados - amoibaios (canto amebeu) - como acontece no Agamémnon de Ésquilo (vv. 1073-1176) entre os velhos e Cassandra, onde esta descreve os horrores passados e futuros; de epinícios ou odes vitoriosas - epinikia - que invocavam o mundo das competiçóes atléticas e do ideal aristocrata do belo e nobre vencedor, como é visível na Electra de Eurípides (vv. 880-889) e de péanes - paianes - como acontece nas Traquinias de Sófocles (vv. 947-970), quando o coro entoa uma destas composiçóes para celebrar o regresso de Héracles a casa, depois dos seus inúmeros trabalhos.

Estas partes cantadas, ainda que frequentemente fossem executadas em uníssono ${ }^{41}$, podiam também ocorrer a solo, na

${ }^{40}$ Segundo Aristóteles (Poética, 12.1452b24), o kommos era um cântico executado simultaneamente pelo coro e pelos atores, ou seja, por toda a cena.

${ }^{41}$ Segundo Pickard-Cambridge (1953: 250), na tragédia, o párodo e os estásimos geralmente eram executados em uníssono. Calame (2005: 230) defende que as prestaçóes dos coros trágicos se caracterizavam pela existência de uma notável polifonia. 
pessoa do corifeu. Outras vezes, o coro desdobrava-se em dois e, enquanto uma das partes cantava, a outra movimentava-se, executando gestos exemplificativos do que estava a ser cantado $^{42}$, embora a imaginação tivesse uma intervenção muito importante aqui, porquanto nem tudo podia ser ilustrado ${ }^{43}$ nem há evidências seguras relativas ao grau de mímica de que os elementos do coro se serviriam quando os atores falavam ou quando eles próprios cantavam.

Esta divisão do coro em dois semi-coros, também no que concerne à repartição das estrofes e antístrofes dos estásimos, ainda que não constituísse uma prática comum, ocorreu contudo, no entender de Pickard-Cambridge (1953: 250), algumas vezes, como se pode comprovar, ainda que por breves instantes, no párodo da Alceste de Eurípides (vv. 77-140) ou ao longo de toda a Lisístrata de Aristófanes, o mesmo sucedendo, ainda na opiniáo do mesmo estudioso, relativamente à parábase da generalidade das comédias, nomeadamente no que concerne à estrofe e à antístrofe.

A divisão do coro em dois semi-coros podia manter-se ao longo de toda a peça ou ocorrer, apenas, em momentos específicos. Em certas peças não há dúvida de que o dramaturgo tenha optado por colocar dois coros distintos a contracenar, como se verifica no final das Euménides de Ésquilo (vv. 1032-1046), quando estas são acompanhadas em cortejo pelos cidadãos até ao seu santuário, ou nas Fenícias de Frínico, representadas em 476 a.C., onde se afigura muito provável a existência de um coro de conselheiros e outro das próprias mulheres fenícias (frs. 8-12 Nauck $^{2}$ ). Segundo Pickard-Cambridge (1953: 242244), também nas Suplicantes de Ésquilo as serviçais devem ter formado um grupo separado das Danaides e, na Lisistrata de Aristófanes, o coro estaria dividido em homens e mulheres.

Noutras ocasióes, atores e coro podiam interagir através de um diálogo lírico, onde cada qual mantinha o seu respetivo modo de elocução - o retórico e o lírico -, como acontece nas Coéforas de Ésquilo, com o coro, Electra e Orestes, e no Agamémnon do mesmo tragediógrafo em relação às figuras de Cassandra e do coro, embora aqui, segundo Rehm (1992: 57),

${ }^{42}$ Segundo Rehm (1992: 54), em termos modernos, a dança dos coros gregos aproximava-se mais da dança sincronizada do que do ballet, recorrendo-se mais a movimentos expressivos do que a abstratos.

43 Sobre a importância das palavras no teatro grego, vide cap. 7, 135-136. 
seja Cassandra a cantar e o coro a falar, até a profetisa arrastar o grupo na sua dança e juntos partilharem o kommos. O diálogo cantado podia também ocorrer entre corifeu e ator ${ }^{44}$.

Relativamente às partes faladas do coro, estas são, frequentemente, atribuídas exclusivamente ao corifeu que incitava ao diálogo, a bem da clareza, como acontece nas Euménides de Ésquilo, quando este elemento assume a representatividade de todas as Fúrias e dialoga com Apolo e Atena. Havia, no entanto, situaçóes em que nos deparamos com variadas vozes do coro, como acontece depois da morte de Agamémnon, na peça homónima de Ésquilo (vv. 1348-1371). Diferentes vozes podiam também ser ouvidas, na identificação de personagens que entravam ou saíam de cena, nas pausas entre longos discursos ou, ainda, quando os elementos do coro serviam de intermediários numa contenda, ajudando o público a perceber que personagem falava, já que o uso da máscara e a distância entre espectadores e performers impedia que aqueles tivessem essa perceção.

Há também exemplos de discursos proferidos por elementos do coro, como o pronunciado pelo corifeu, no Héracles de Eurípides (vv. 252-274), mais extenso do que o papel conferido a algumas personagens, como, por exemplo, a Egisto, nas Coéforas (vv. 838-869) de Ésquilo.

Quando o coro falava com os atores, fazia-o à maneira destes, servindo-se do trímetro iâmbico, metro também usado na comédia, nomeadamente na parábase. Outras vezes, servia-se do tetrâmetro trocaico, mas, nesses casos, quando o modo de elocução era o recitativo, que geralmente estava associado a cenas de grande tensão e suspense e também à entrada do coro em cena. Esta, por norma, ocorria no início das peças ${ }^{45}$ e era feita através de uma ou de ambas as entradas laterais do teatro - as parodoi - nome por que ficou também conhecida, em termos estruturais, a primeira intervenção do coro, exatamente por, em geral, coincidir com este movimento.

${ }^{44}$ Cf. Belessort (1934: 39).

45 Seale (1982: 14) defende que, convencionalmente, o coro entrava muito antes de a peça começar e só saía, com raras exceçóes, no final. 


\section{6 - Movimento}

Embora a tradição aponte para a entrada do coro em marcha militar coordenada com os anapestos, a verdade é que são escassas as tragédias onde realmente isso acontece ${ }^{46}$, sendo que, no entender de Herington (1985: 121), o movimento associado aos anapestos não era obrigatoriamente o de marcha, já que, inclusivamente, este metro podia ser utilizado estando o coro em posição estática ${ }^{47}$. Já Pickard-Cambridge (1953: 248) defende que a entrada em marcha é visível em muitas das primeiras tragédias, nas quais a estrofe e a antístrofe são precedidas de cerca de quarenta a sessenta e cinco dímetros anapésticos que, provavelmente, eram enunciados em recitativo. Nesta situação estariam as Suplicantes, os Persas e o Agamémnon de Ésquilo, o Ájax de Sófocles, e a Alceste, o Reso e a Hécuba de Eurípides.

De qualquer forma, embora sejam escassos os testemunhos sobre a movimentação do coro, a verdade é que, segundo a tradição, do movimento circular, típico dos coros ditirâmbicos, ter-se-á evoluído para uma formação triangular de cariz militar ${ }^{48}$, porquanto os movimentos eram executados unissonamente e de forma compassada. No entanto, na opinião de Calame (1977: 79-86) e exatamente por causa da relação direta entre danças corais e dramáticas, esta evolução não terá ocorrido de uma forma abrupta e muito acentuada. Assim sendo, parece plausível, até pelo número de coreutas que integravam as primeiras tragédias, que, inicialmente, quando a interação entre coro e atores era plena, o movimento dos primeiros

${ }^{46}$ Entre os poucos exemplos, contam-se os Persas e o Agamémnon de Ésquilo. Segundo Herington (1985: 113), todas as evidências parecem apontar para a origem desta formação em Esparta, pelo menos a partir do século VII a.C., sendo que, desde essa altura, não há registos do seu uso em qualquer outra circunstância, até ao seu reaparecimento nas tragédias gregas. De qualquer forma, desconhece-se em que data a marcha anapéstica passou a estar incorporada nos dramas.

${ }^{4}$ Da mesma opinião partilha Rehm (1992: 27), que defende que, da análise de cenas como o kommos entre o coro, Orestes e Electra, nas Coéforas, o cântico das Fúrias à volta de Orestes ou os seus vaticínios sobre a cidade de Atenas, no final das Euménides de Ésquilo, se constata que a tese de que o coro apresentava geralmente uma configuração militar não se verifica nos momentos mais intensos da performance.

${ }^{48}$ Prova disso é que o esquema métrico utilizado nas partes correspondentes ao coro estava mais vocacionado para o recitativo e, por conseguinte, para uma movimentação em marcha lenta. 
tendesse a ser circular ${ }^{49}$, tendo evoluído para retangular e depois para triangular, quando o ator assumiu um papel de relevo face ao coro e quando este passou a ser constituído por quinze elementos, número que permitiu a formação do coro em triângulo ou retângulo e simultaneamente o destaque da figura do corifeu ${ }^{50}$, que desempenhava um papel de extrema importância não só porque oralmente era, muitas vezes, o seu porta-voz ${ }^{51}$, mas também porque se distinguia na liderança da movimentação do coro.

Segundo Csapo \& Slater (1994: 353), o coro estava organizado numa hierarquia rígida, análoga à formação em linha dos hoplitas, quando se preparavam para uma batalha ${ }^{52}$. Esta formação retangular consistia na distribuição dos quinze elementos por três filas (zyga) com uma linha de cinco coreutas cada (stoichoi $)^{53}$, sendo que, quando o coro marchava, a sua organização podia ser a de uma frente com três elementos - kata zyga - ou com cinco - kata stoichous ${ }^{54}$. Geralmente a entrada do coro ocorria na formação kata zyga, sendo que os elementos do coro que mais se destacavam posicionavam-se na fila mais à esquerda (aristerostata), que ficava mais próxima da audiência, ladeando o corifeu, situado no centro da fila ${ }^{55}$. Os elementos menos capazes surgiam na fila central (laurostata ou deuterostata), de forma a passarem mais despercebidos aos

${ }^{49}$ A confirmá-lo parece estar o verso 309 das Euménides de Ésquilo, onde se evoca a dança em roda. Além disso, um escólio à Hécuba de Eurípides, 647, atribui um movimento rotativo simétrico, à direita, à estrofe, e um, à esquerda, à antístrofe que, juntamente com o epodo, altura em que não havia movimentação, constituíam os estásimos. Vide ainda Aristófanes, Mulheres que celebram as Tesmofórias, 953 sqq.; 966 sqq.; Eurípides, Ifigénia em Aulide, 1480-1; Héracles, 987-93.

${ }^{50}$ Segundo Wiles (2000: 135), há relatos que evidenciam que este papel de elevada importância chegou a ser desempenhado por cidadãos que acumulavam quer as funçôes de corego quer de chorodidaskalos.

${ }^{51}$ Wiles (2000: 135) discorda que somente o corifeu tomasse a palavra nas partes dialogadas que se destinavam ao coro e que não eram dançáveis, já que, como os atores usavam máscaras, uma voz a solo que emanasse de uma multidão não seria identificada.

52 Da mesma opinião partilha Stanford (1983: 88), que defende que as danças corais se caracterizavam por um certo caráter geométrico, quando os elementos tomavam a sua posição em filas organizadas.

53 Vide Pólux, 4.108-9.

${ }^{54}$ Segundo Hesíquio (s.v. grammai), havia linhas marcadas no chão, de forma a permitir que o coro ficasse alinhado e a frente retilínea.

55 Vide Fócio, s.v. tritos aristerou. 
espectadores. Os coreutas que ladeavam o corifeu, no centro da primeira fila, designavam-se por parastatai, e vinham logo a seguir a este em termos de importância. Num conjunto de outras tragédias que não se iniciavam com anapestos, como a Antígona, o Rei Édipo, as Traquinias, o Filoctetes de Sófocles, o Hipólito, a Andrómaca, o Héracles, o Ín, a Electra e a Ifigénia em Áulide de Eurípides, Pickard-Cambridge (1953: 248-249) defende que o coro deve ter entrado em cena a entoar o párodo, como parece mais provável, ou numa marcha silenciosa, em formação kata zyga, ao som do tocador de flauta ${ }^{56}$, até encarar a audiência, altura em que começaria a cantar.

De qualquer forma, não era forçoso que a entrada do coro ocorresse nesta formação kata zyga, sendo que podia ocorrer também em formação kata stoichous, ou então numa única fila, inclusivamente de forma desorganizada ${ }^{57}$, ou ainda numa variedade de outras formas. Assim, embora houvesse realmente entradas em procissóes formais, como no início das Coéforas de Ésquilo ${ }^{58}$, quando as cativas se preparam para prestar libaçôes sobre o túmulo de Agamémnon, outras há, como as Euménides de Ésquilo, onde se vislumbra, tendo em conta a tradição, que o aparecimento do coro terá ocorrido de forma desordenada, sem qualquer caráter militar, já que, segundo a tradição, os elementos ter-se-ão deslocado em grupos de dois e três, ao mesmo tempo que se faria ouvir um rugido hediondo, fora de cena ${ }^{59}$.

D'Arnott (1989: 24) sugere ainda que o coro do Prometeu Agrilhoado de Ésquilo terá feito a sua entrada em cena num nível superior ao da skene, provavelmente executando uma dança ilustrativa de um voo, já que este coro aparece caracterizado como constituído por Oceânides, ninfas aquáticas, aladas, filhas do deus do mar, Oceano, e só depois terá tomado a posição acostumada na orquestra. Há ainda exemplos de peças em que se pressupóe a presença do coro logo desde o início, sem que a sua entrada em cena fosse grandemente notada, como nas

56 O acompanhamento da flauta quer nas entradas quer nas saídas de cena do coro era recorrente, pelo menos nas tragédias. Vide escólio a Aristófanes, Vespas, 582.

${ }^{57}$ Pickard-Cambridge (1953: 246) defende que era o que, geralmente, acontecia na comédia.

58 Segundo Pickard-Cambridge (1953: 249), esta entrada ter-se-á desenrolado de forma silenciosa.

${ }^{59}$ Vide Rehm (1992: 53). 
Suplicantes de Eurípides, ou cuja entrada tenha ocorrido em simultâneo com a personagem principal, como nas Bacantes do mesmo tragediógrafo.

Em relação à comédia, Pickard-Cambridge (1953: 246) defende que a formação retangular vulgarmente usada na entrada em cena por parte do coro era a que consistia na distribuiçáo dos vinte e quatro elementos por quatro filas, cada uma das quais composta por seis coreutas. No entanto, a entrada em marcha não era obrigatória e assim, por exemplo, segundo Csapo \& Slater (1994: 353), ela não ocorreria nas Aves de Aristófanes.

Geralmente, o coro mantinha-se em cena durante toda a peça ${ }^{60}$ e, no final da maioria dos dramas, abandonava a orquestra através das parodoi, naquilo que constituía a saída ou exodos $^{61}$. Havia, no entanto, outras peças, como as Euménides de Ésquilo, o Ajax de Sófocles ou a Helena de Eurípides, em que o coro abandonava por momentos a orquestra, antes ainda de a peça acabar - operando uma 'deslocação' ou 'mudança' (metastasis) $^{62}$ e protagonizando um segundo párodo quando voltava a entrar em cena. Segundo Pickard-Cambridge (1953: 246), a sua reentrada em cena (epiparodos) podia ocorrer de variadas formas e assim, por exemplo, nas Euménides de Ésquilo (v. 243), as Fúrias terão entrado novamente em cena de forma dispersa; no Ájax de Sófocles (v. 866), os dois semi-coros terão reentrado através das duas parodoi, ao passo que, na Alceste de Eurípides (v. 861), o coro parece ter recorrido à formação kata zyga. Estas ausências temporárias de cena podiam servir para indicar uma importante mudança de cenário, como acontece, por exemplo, nas Euménides de Ésquilo (v. 235 sqq.) do templo de Apolo para Atenas. Fosse como fosse, o facto é que, geralmente, as últimas palavras que a audiência ouvia, antes do final das peças, eram sob a forma de cântico, ainda que,

${ }^{60}$ Wiles (2000: 143) acrescenta que não havia conversas privadas nas tragédias gregas, porque o coro estava sempre presente como uma espécie de assembleia ou júri, julgando como justas ou injustas as palavras que iam sendo proferidas. Este facto criava no entanto, no dizer de Harsh (1994: 21), situaçóes por vezes constrangedoras. Por exemplo, no Hipólito de Eurípides, o coro poderia ter salvado a vida de Hipólito revelando a verdade, mas não o faz.

${ }^{61}$ Por exemplo, no final dos Persas de Ésquilo, o coro acompanha Xerxes derrotado de regresso a casa; no final das Traquinias de Sófocles, o coro toma parte no cortejo fúnebre de Héracles.

${ }^{62}$ Vide Pólux, 4.108. 
habitualmente, os mesmos fossem breves e muito sumários. Em Eurípides, a exodos parecia não ser muito importante, já que existem pelo menos três peças - a Alceste, a Medeia e as Bacantes- que terminam praticamente da mesma forma.

Na comédia, e nomeadamente em Aristófanes, era frequente as peças terminarem de uma forma hilariante, tal como também geralmente começavam, através de um festejo ou de uma espécie de orgia, típicos do komos, que conjugava coro e atores. Exemplos disso são os Acarnenses, os Cavaleiros, as Vespas, a Paz, a Lisistrata, as Mulheres na Assembleia e as Rãs. Segundo D’Arnott (1989: 39), há algumas evidências relativas à existência de um komos pré-dramático, até pela possível origem etimológica da palavra 'comédia', proveniente da junção dos vocábulos, komos e ode 'cançáo'. De qualquer forma, e ainda na opiniáo do autor, esses finais festivos serviam sobretudo para marcar o termo das peças, de uma forma apoteótica, já que náo se podia recorrer a mecanismos modernos, como baixar o pano ou apagar as luzes, para indicar essa situação.

\subsection{1 - DANÇA}

Ainda que se desconheça a natureza precisa da dança dos coros gregos, é no entanto possível retirarem-se algumas conclusóes a partir da substância da música, da observação de vasos gregos que contêm representaçóes de danças corais ${ }^{63} \mathrm{e}$ dos próprios esquemas métricos, embora seja difícil associar esquemas métricos específicos a determinados movimentos.

Assim, há indícios que permitem afirmar que, tal como os atores, o coro executava também danças miméticas e expressivas e, por isso, é expectável que quando o coro, cantando, se referisse, por exemplo, a rituais de luto ou a forças da natureza, os coreutas realizassem gestos identificativos e ilustrativos dessas realidades. Tal como acontecia com o canto, o movimento do coro ocorria, geralmente, em uníssono, embora fosse provável existirem também danças a solo, enquanto os outros elementos permaneceriam com um ritmo base. Quando, como era frequente, o coro se desdobrava em dois e metade cantava e a outra dançava, estes últimos executavam um conjunto de

${ }^{63}$ Exemplo disso é o vaso Basileia. Vide supra cap. 3, n. 37. 
movimentos, designados de marcha, e de pausas, designadas de figuras, as quais pretendiam retratar situaçóes.

Enquanto, na tragédia, era uma honra dançar e era expectável que fosse algo que fizesse parte da educação de um jovem, na comédia, a responsabilidade era menor e os movimentos que os coreutas tinham de executar tinham muito pouco de honroso, porquanto as mais das vezes evidenciavam posturas disformes. Daí Platão (Leis, 816-7) considerar que os coros cómicos eram compostos por pessoas defeituosas com um aspeto degradado e que, por isso, a comédia devia destinar-se a escravos e estrangeiros.

Relativamente aos movimentos executados pelos coros cómicos, ainda que se careça de informação, sabe-se, no entanto, a partir das próprias peças, que havia uma grande variedade e liberdade na realização dos mesmos, quer na entrada em cena do coro, quer na sua retirada, sendo que esta geralmente se efetuava através de uma dança vigorosa, como acontece nas Vespas e nas Mulheres na Assembleia de Aristófanes. 
(Página deixada propositadamente em branco) 
7 - Público 
(Página deixada propositadamente em branco) 
O destino último das performances teatrais ocorridas nos festivais dionisíacos era o da obtenção do primeiro lugar nas competiçóes e, para isso, contribuía largamente a opinião do público, a quem o poeta procurava agradar, já que a sua atitude podia influenciar o voto do júri ${ }^{1}$ - as claques organizadas à volta de cada poeta e que torciam pelas suas composiçóes são bem um exemplo disso ${ }^{2}$. Acresce ainda o facto de qualquer artista em competição pretender alcançar a simpatia da audiência por esta ser participativa e manifestar de forma explícita o seu agrado ou desagrado relativamente a uma determinada performance, através de risadas e aplausos ou de assobios ${ }^{3} \mathrm{e}$ pateadas ${ }^{4}$, cujo barulho era ensurdecedor, sobretudo quando os assentos eram ainda de madeira e não de pedra ${ }^{5}$ e, por isso, comprometia seriamente o natural desenrolar de uma determinada peça ${ }^{6}$. Quando o desempenho dos atores também não era o mais desejável, frequentemente os espectadores arremessavam objetos ${ }^{7}$, em especial alimentos trazidos consigo, como tomates ou ovos. Estas situaçóes eram, no entanto, exceção, uma vez que, por um lado, todo o tipo de violência à volta das Dionísias era considerado um sacrilégio e, portanto, era objeto de citação perante a justiça (probole) na Assembleia que decorria no templo depois das festividades e que se destinava sobretudo a julgar delitos desta natureza ${ }^{8}$. Por outro lado, a

${ }^{1}$ Nas Leis, 2.659a-b, Platão afirma: "Não deve acontecer que, no teatro, o júri se deixe impressionar pelo barulho da multidáo e retire, da sua própria ignorância, a verdade... porque não reside no aluno mas sim no mestre o juízo das representaçóes”. Sobre o método de seleção do júri dos concursos, vide cap. 1, 27-28.

${ }^{2}$ Cf. Álcifron, Epistológrafo, 3.35.3; Aristófanes, Acarnenses, 658.

${ }^{3}$ Vide Rehm (1992: 30).

${ }^{4}$ Esta era uma das formas mais comuns de demonstrar a insatisfação perante o espetáculo presenciado.

5 Sobre a evolução do edifício teatral, vide cap. 2 .

${ }^{6}$ Segundo D' Arnott (1989: 6) existem numerosas histórias de audiências que arruinaram espetáculos, gritando, atirando fruta ou praticando atos ainda piores.

${ }^{7}$ Cf. Demóstenes, Sobre a falsa embaixada, 337.

${ }^{8}$ No Discurso Contra Mídias, 178-180, Demóstenes lembra a severidade da legislação ateniense: Ctésicles foi condenado à morte por ter atingido um dos seus inimigos durante a procissão das Grandes Dionísias. Um outro homem, ainda que fosse assessor e pai do arconte em vigor, foi censurado por ter expulsado e batido num espectador que havia tomado um lugar errado. 
polícia do teatro - os rhabdoucho $i^{9}$ - estava incumbida de moderar as manifestaçóes de violência ${ }^{10}$, pelo que qualquer falha era punida severamente.

Ainda assim, estas atitudes ruidosas, participativas e indisciplinadas faziam-se sentir mais na comédia do que na tragédia, como se pode facilmente depreender pela própria natureza do género. De qualquer forma, esta situação resultava, em parte, do facto de estarmos a lidar com acontecimentos que decorriam em espaço aberto e que permitiam que o conjunto dos espectadores não só avistasse os atores como também todos aqueles que os rodeavam, daí Stanford (1983: 14) considerar que a audiência era um grupo unido, um thiasos, não uma coleção de individualidades.

Exatamente por causa deste contacto direto e do extenso número de horas durante as quais decorriam as performances, os espectadores necessitavam de elevados níveis de concentração ${ }^{11}$. Além disso, como não havia nenhum efeito de luz ou artefacto que acusasse o início de uma determinada peça, e porque, nas comédias, o público se apresentava mais relaxado e jocoso, os comediógrafos, particularmente Aristófanes, tiveram de recorrer a outros meios para indicarem a abertura da representação e para captarem o interesse e a atenção dos espectadores. Assim, no geral, existiam duas maneiras de iniciar uma comédia: ou de forma hilariante, através de uma brincadeira rápida e ruidosa, como nos Cavaleiros, na Paz ou nas Aves de Aristófanes, ou com uma sequência de tópicos e piadas insignificantes, tal como acontece nos Acarnenses, nas Vespas ou nas Rãs do mesmo comediógrafo. Os prólogos serviam também esta finalidade de, a pouco e pouco, captarem a atenção do espectador, sendo que era irrelevante que as primeiras frases não fossem ouvidas, já que os conteúdos importantes eram só mencionados quanto o interesse do público havia já sido despertado ${ }^{12}$.

Esta proximidade existente entre atores e espectadores era não só física, porquanto não havia qualquer fronteira que

9 À letra, 'portadores do bastão'. Cf. Aristófanes, Paz, 734-47.

${ }^{10}$ Cf. Demóstenes, Contra Midias, 179; Platão, Leis, 3.700c.

${ }^{11}$ Ghiron-Bistagne (1976: 196) elogia a capacidade de atenção e paixão dos espectadores gregos, que assistiam às performances durante seis a oito horas.

12 Já na tragédia, e como os prólogos são mais informativos, D’Arnott (1989: 7) acredita que, pela seriedade inerente ao género, tendencialmente a audiência fosse, logo desde início, mais recetiva. 
delimitasse o recinto reservado aos atores e espectadores, como também intrínseca ao desenrolar da própria peça; daí que, náo raras vezes, o público fosse chamado a participar como interveniente na mesma. É o que acontece, por exemplo, nas Euménides de Ésquilo ${ }^{13}$, onde a audiência acaba por se identificar com os cidadãos que estariam presentes no Areópago para julgarem o crime perpetrado por Orestes, ou nos Acarnenses de Aristófanes, onde o público acaba por desempenhar o papel dos participantes na Assembleia.

Na comédia, esta proximidade era ainda mais sentida, já que os atores, muitas vezes, se dirigiam diretamente à assistência ${ }^{14}$. Veja-se o caso de Diónisos, nas Rãs de Aristófanes (v. 298), que interpela o verdadeiro sacerdote do deus, sentado na primeira fila do teatro ${ }^{15}$. Outras vezes, chegavam mesmo a "admoestá-la" fisicamente, como quando a saraivavam com nozes e frutos ${ }^{16}$. De qualquer forma, e segundo D'Arnott (1989: 13), o momento em que esta proximidade se tornava mais evidente era aquando da parábase, existente na maior parte das comédias conservadas, e que era a altura em que o coro quebrava a ilusão cénica e se dirigia diretamente à audiência.

A constituição desta audiência é, no entanto, uma questão que tem levantado alguma controvérsia já que, embora tendencialmente os espectadores das performances teatrais tenham vindo a ser identificados com o corpo dos cidadãos atenienses ${ }^{17}$, não só porque se vislumbra a partir de alguns passos de comédias e até de tragédias que assim fosse, como também pelo facto de os festivais serem reconhecidos como ocasiôes artísticas, religiosas e cívicas, há, em todo o caso, estudiosos como Sommerstein (1997: 64) que acreditam que, independentemente da performance dramática considerada,

13 Segundo D’Arnott (1989: 17), nesta tragédia, a participação da audiência é progressiva, cumulativa e, no final, total.

${ }^{14}$ Stanford (1983: 14) defende mesmo que, na comédia, atores e coro podiam deslocar-se e tocar nos espectadores. Já na tragédia, as convençôes inerentes ao género proibiam que isso acontecesse. Vide Sommerstein (1997: 65).

${ }^{15}$ Outros exemplos podem ainda ser citados, como sendo a interpelação direta do coro à audiência nas Aves (1071 sqq.) de Aristófanes, ou de Estrepsíades nas Nuvens (1201 sqq.) do mesmo comediógrafo.

${ }^{16}$ Aristófanes (Vespas, 58-59) lista esta como uma das características mais familiares da comédia.

${ }^{17}$ Assim o tem defendido, por exemplo, Zeitlin (1990: 65). 
muitos cidadãos adultos, masculinos, não a terão presenciado, ao passo que muitos outros que não reuniam estas condiçóes o terão feito.

Assim, para além de todo o tipo de cidadãos que estariam presentes, fosse qual fosse a sua categoria profissional ou nível de formação - artesãos, agricultores, sacerdotes, poetas, filósofos (o que a este nível é representativo da dimensão democrática dos festivais) - é hoje cada vez mais aceite que também os escravos $^{18}$, as crianças e as mulheres tinham assento no teatro ${ }^{19}$. Relativamente a estes últimos intervenientes, muito se tem discutido sobre o assunto, sendo que existem fontes credíveis para a defesa de ambas as teses, ou seja, para os que acreditam que a sua presença nos festivais fosse uma realidade e para os que assim náo o entendem.

No que concerne aos primeiros, é comum aludir-se à tradição ${ }^{20}$ que dá conta de como as mulheres grávidas que assistiam à representação da Oresteia abortaram em consequência da imagem terrífica das Fúrias. São ainda tidos como argumentos que abonam a favor desta perspetiva os testemunhos de obras como a Paz (vv. 962-967) e as Nuvens (537-539) de Aristófanes, ou as Leis $(7.817 \mathrm{c})$ de Platão.

De qualquer forma, entre aqueles que se inclinam mais para aceitar a sua presença ${ }^{21}$, há quem seja de opinião, como Sommerstein (1997: 65), de que o seu número não era muito avultado, ou ainda de que existiriam lugares especiais para as mulheres, como defende Pickard-Cambrige (1953: 269) 22 , e

${ }^{18}$ Cf. Platão, Górgias, 502d.

${ }^{19}$ Ghiron-Bistagne (1976: 196) advoga que, a partir de Teofrasto (Caracteres, 9.5), é possível afirmar-se que as crianças eram admitidas no teatro, mesmo nas comédias mais obscenas, tal como os escravos e as mulheres. Também da Paz (vv. 765-6) de Aristófanes se depreende a sua presença.

${ }^{20}$ Vida de Ésquilo, p. 4; Pólux, 4.110; Pausânias, 1.28.6.

${ }^{21}$ Estão nesse caso estudiosos como Pickard-Cambridge (1953: 268-9), Rehm (1992: 29) e Csapo \& Slater (1994: 286).

${ }^{22}$ Pickard-Cambridge baseia-se num escólio a Aristófanes (Mulheres na Assembleia, 22) que acrescenta que, nos finais do séc. V, inícios do séc. IV a.C., elas não só estariam afastadas dos homens, como haveria distinção de lugares para mulheres livres e cortesãs. 
que lhes era vedado assistirem às comédias, conforme sustenta Belessort (1934: 42).

Relativamente aos estudiosos que defendem a sua ausência ${ }^{23}$, é comum basearem-se nas comédias ${ }^{24}$ desde o século $\mathrm{V}$ até ao III a.C. que, geralmente, se referem ao público como se ele fosse constituído apenas por homens, ainda que de várias idades ${ }^{25}$.

Há ainda aqueles que se mantêm na dúvida, tal como Murnaghan (2005: 234), que argumenta que a questão se torna bastante complicada, dada a multifacetada natureza das Grandes Dionísias, já que, se por um lado, enquanto ocasião pública, seria de pressupor a presença das mulheres, por outro, enquanto acontecimento político, deveria destinar-se apenas a homens.

Controvérsias à parte, é no entanto unanimemente aceite que, ao contrário das Leneias, onde era permitida a entrada apenas a cidadãos e a metecos ${ }^{26}$, às Grandes Dionísias os estrangeiros podiam assistir ${ }^{27}$ e, por isso, elas ocorriam numa altura do ano em que a navegação era possível.

Este público assim tão variado, composto por homens cultos e outros iletrados, mulheres, crianças, estrangeiros e escravos, era bem um reflexo da democracia que vigorava em Atenas, no século $\mathrm{V}$ a.C. ${ }^{28}$. De qualquer forma, podem traçar-se algumas características comuns a este thiasos, para nos servirmos da expressão de Stanford: a capacidade de concentração ${ }^{29}$,

${ }^{23}$ E.g. Zeitlin (1990: 65).

${ }^{24}$ Por exemplo, nas Aves de Aristófanes (793-6), de onde se depreende que, enquanto os maridos assistiam às performances, as mulheres estariam em casa: "Se um de vocês anda de amores e dá de caras com o marido da fulana, no sector dos Conselheiros, com um bater de asas póe-se a voar dali; vai fazer amor lá fora e ei-lo de volta a voar outra vez". Tradução: Maria de Fátima Silva, (Lisboa, Ediçōes 70, 1989).

${ }^{25}$ Csapo \& Slater (1994: 286) defendem, no entanto, que essa forma de tratamento é apenas um reflexo social e retórico, resultante do facto de quer as assembleias quer os tribunais integrarem apenas homens.

${ }^{26}$ Vide Aristófanes, Acarnenses, 501-8.

${ }^{27}$ Vide Eliano, História Vária, 2.13. Pickard-Cambridge (1953: 268) refere que muitos destes estrangeiros eram pessoas distintas, convidadas para lugares de honra.

${ }^{28}$ Segundo D’Arnott (1989: 24), a história das intervençôes corais e da democracia em Atenas é coexistente: quando as primeiras declinam, isso é já um reflexo do declínio da segunda.

${ }^{29}$ Segundo Pickard-Cambridge (1953: 281), que a audiência funcionava como um todo e vivia a peça intensamente é demonstrado por histórias que 
imposta pelo largo período de tempo em que decorriam as performances e pelo facto de o contacto visual entre espectadores ser uma constante; o gosto eclético, resultante da predisposição coletiva para assistir indiferentemente a comédias, tragédias ou dramas satíricos ${ }^{30}$, e a sensibilidade e destreza no saber ouvir, decorrentes do facto de ser um povo habituado a escutar longas rapsódias ${ }^{31}$. Este hábito familiar da vida dos gregos trazia ainda outra vantagem, a de que grande parte da população conhecia bem os mitos, pelo menos na perspetiva de Homero ${ }^{32}$, o que lhes permitia acompanhar com melhor eficácia o desenrolar das peças ${ }^{33}$. Daí que Wiles (1997: 208-9) afirme que, para o espectador grego, o significado da história não estava na história per se, mas na maneira como a mesma aparecia retratada e na forma como se diferenciava de outras retrataçóes. A este respeito é paradigmático o exemplo da Helena

dáo conta, por exemplo, de como os espectadores rebentaram num pranto quando movidos pelo talento de um ator de qualidade, como Calípides (Xenofonte, Banquete, 3.11).

${ }^{30}$ Esta característica do povo grego levou Pickard-Cambridge (1953: 284) a considerar que o mesmo devia possuir um elevado nível de seriedade e inteligência. De qualquer forma, haveria tendências e sensibilidades distintas. Nas Leis (2.658a-d) de Platão, o interlocutor ateniense declara que se a audiência tivesse de escolher de entre os entretenimentos públicos aquele que lhe oferecia maior prazer, os rapazinhos optariam pelas artes mágicas, os rapazes mais velhos pelas comédias, enquanto as mulheres educadas, os jovens e os espectadores em geral dariam preferência à tragédia.

${ }^{31}$ D’Arnott (1989: 78-79) considera que os recitais épicos dos bardos pressupunham uma audiência com sofisticação intelectual suficiente para os acompanhar, habituada a entender paralelismos ou a identificar assonâncias. Na mesma esteira, Schlesinger (1963: 40) acredita que as partes líricas da tragédia pusessem à prova a capacidade de apreciação dos gregos.

${ }^{32}$ Stanford (1983: 18) acredita que mesmo a audiência mais ignorante conheceria as linhas gerais do mito (por exemplo, os filhos de Tiestes comidos pelo pai, Agamémnon assassinado pela mulher) e que, por isso, apesar de, muitas vezes, se saber o que ia acontecer, não se sabia quando nem onde. Já Aristóteles, na Poética (1.1451b25-6), refere que apenas uma parte da audiência conheceria de antemão os temas tratados nas peças. De qualquer forma, Pickard-Cambridge (1953: 284) admite que, em qualquer dos casos, o conhecimento prévio das linhas gerais da ação era um requisito menor para julgar ou apreciar uma determinada peça.

${ }^{33}$ Uma outra fonte de conhecimento dos mitos resultava do facto de grande parte da audiência ter já participado noutros festivais, enquanto membros de coros, já que esta era uma atividade de caráter voluntário; daí que D’Arnott (1989: 23) conclua que audiência e coro estavam unidos espiritual e espacialmente. 
de Eurípides, que o tragediógrafo concebe como tendo estado sempre no Egito, durante a guerra de Troia e que, certamente, terá surpreendido os espectadores.

Relativamente à comédia, esta questão não se colocava, sendo que Antífanes (frag. 189K-A) refere que, por isso, as tragédias tinham vantagem porque se serviam de temas familiares aos espectadores. De qualquer forma, pressupunham também uma audiência informada, já que, não raras vezes, eram feitas nas comédias, sob a forma de paródia, referências múltiplas, de maneira implícita ou explícita, a acontecimentos ou partes de tragédias, como aconteceu nas Rãs de Aristófanes (v. 1471), onde o comediógrafo recorreu a palavras utilizadas por Eurípides no Hipólito. Este reconhecimento que se estima que os espectadores tenham feito, apesar de passados 23 anos sobre a representaçáo da tragédia, levou D’Arnott (1989: 78-79) a considerar que os Gregos preservavam a memória das peças. Significativos eram também, na opinião de Ghiron-Bistagne (1976: 202), outros atributos desta audiência, como sendo a inteligência e o bom gosto, comprovados pelo facto de, na generalidade, a mesma se revelar fiel aos seus artistas preferidos, o que é bem um exemplo de reconhecimento de talento ${ }^{34}$.

Da natureza deste público ressaltava ainda a capacidade de resistência, decorrente do facto de o mesmo passar largas horas no teatro a assistir ao desenrolar das peças, o que o obrigava a ter determinados cuidados. Assim, como as performances ocorriam logo de manhã, implicavam, por vezes, longas caminhadas até ao recinto do teatro e porque decorriam durante todo o dia, os espectadores preveniam-se, tomando uma boa refeição, bebendo vinho ${ }^{35}$ e comendo fruta, ao longo do dia, de forma a recuperar energias. Provavelmente alguns, na opinião de Pickard-Cambridge (1953: 279), que se baseia num passo das Aves de Aristófanes (vv. 786-789) para o afirmar, abandonariam o teatro por breves instantes e dirigir-se-iam a casa para uma refeição. Outras fontes ${ }^{36}$ revelam que eram

${ }^{34}$ Recorde-se que, várias vezes, poetas como Ésquilo, Sófocles e Eurípides saíram vitoriosos dos concursos, em detrimento de outros poetas, considerados à luz dos nossos dias de menor valor.

${ }^{35}$ Vide Platão, Leis, 6.775b e Filócoro, citado em Ateneu, Deipnosofistas, 11.464f. Plutarco (No Banquete, 656c) defende que a ingestão de álcool estimularia a imaginação do público e confundir-lhe-ia o intelecto.

${ }^{36}$ E.g. Aristófanes, Paz, 962-967. 
distribuídas provisões, no próprio teatro ${ }^{37}$, que eram consumidas, na perspetiva de Aristóteles (Ética a Nicómaco, 10.1175b 1), quando as peças não tinham qualidade.

Inicialmente, tudo indica que os espetáculos fossem gratuitos, mas, a partir de determinada altura, todos os espectadores, cidadáos ou estrangeiros, começaram a ter que pagar para aceder ao teatro, pelo que, por isso, os festivais dramáticos acabam por não ser considerados um tipo de ocasião cívica, normal, porquanto em nenhuma outra festividade se verificava esta situação. Este pagamento, conhecido como theorikon, foi estabelecido em meados do século $\mathrm{V}$ a.C. ${ }^{38}$ e teve como finalidade evitar as disputas que comummente aconteciam para se assegurar um lugar ${ }^{39}$, limitando o número dos mesmos e delimitando, através de muros, o recinto do teatro ${ }^{40}$. Foi, então, criado um fundo público ${ }^{41}$, de forma a que os cidadãos pobres pudessem também aceder aos bilhetes, através da disponibilização garantida pelo Estado de dois óbolos ${ }^{42}$, quantia indispensável para se proceder à compra dos mesmos e que náo podia ser utilizada para qualquer outro fim.

Pickard-Cambridge defende que era o próprio Estado que pagava essa quantia por cada um dos lugares ao responsável

37 Segundo Csapo \& Slater (1994: 290), esta distribuição fazia parte do rol de encargos dos coregos cómicos.

${ }^{38}$ Segundo Wiles (1997: 59), as fontes associam esta alteração a Péricles. Cf. Plutarco, Péricles, 9.

${ }^{39}$ Wiles (1997: 59) refere que fontes antigas atestam que antes do teatro em pedra ter sido construído, as pessoas optavam por guardar lugares durante a noite e havia anarquia na forma como os tentavam reclamar. Vide Escólio a Luciano, Tímon, 49.

${ }^{40} \mathrm{Na}$ opiniấo de Csapo \& Slater (1994: 288), esta foi também uma forma de estabilizar o preço dos bilhetes, para permitir acessibilidade universal; ou seja, pretendeu-se assim estabelecer um preço de referência, para evitar as especulaçóes do "mercado negro", como hoje em dia também acontece.

${ }^{41}$ Ulpiano (Sobre Demóstenes, Olintíaca, 1.1) afirma que a luta entre cidadãos e estrangeiros começou a ser tão violenta, e o preço dos lugares, praticado pelo responsável pelo recinto teatral, tão abusivo, que, para dar aos pobres a oportunidade de acederem aos bilhetes, Péricles instituiu um fundo teórico a partir do qual era atribuído dinheiro para se comprarem lugares.

${ }^{42}$ Cf. Demóstenes, Sobre a Coroa, 28. De acordo com Filócoro (História da Ática, 3), a soma paga ascendia a uma dracma, mas, segundo Pickard-Cambridge (1953: 271), essa quantia podia resultar do pagamento dos três dias em que decorriam as tragédias. Também no escólio a Luciano (Tímon, 49) a quantia referida é uma dracma. 
do edifício teatral - conhecido como architekton, theatrones ou theatropoles - sendo que, depois, os bilhetes eram distribuídos aos cidadáos pelas autoridades de cada demo. Relativamente aos lugares de honra, concedidos pelo Estado e que contemplavam arcontes $^{43}$, generais ${ }^{44}$, sacerdotes, órfãos de guerreiros mortos no campo de batalha, benfeitores e embaixadores de estados estrangeiros, desconhece-se se os mesmos estavam também sujeitos ao pagamento de bilhete ${ }^{45}$.

Os bilhetes, de bronze ou chumbo, decorados com a cabeça de Atena e outros símbolos, possuíam letras de acordo com o lugar a que se destinavam. Bilhetes com apenas uma letra diziam respeito aos lugares existentes na primeira galeria, com duas, uma de cada lado, à segunda, e com duas letras em cada um dos lados, à terceira. Estes últimos eram, no entanto, raros, porquanto esta galeria possuía apenas 10 pequenas secçóes em forma de cunha, enquanto a segunda tinha 14 secçóes inteiras.

Os espectadores que ficavam nos lugares mais cimeiros eram os que enfrentavam maiores dificuldades de visualização, já que a distância entre estes e os atores podia ascender a quase cem metros ${ }^{46}$. De qualquer forma, os gestos mais largos eram percetíveis e acredita-se que o público não estaria limitado em termos auditivos, já que, tal como Ghiron-Bistagne (1976: 196) sublinha, as soberbas condições acústicas dos teatros gregos e, presume-se, a nítida e bem projetada voz dos atores permitiam que as palavras e a música chegassem aos mais distantes espectadores, o que é bem ilustrativo do lugar de destaque que a palavra tinha no teatro grego. Assim, embora os termos gregos usados para 'teatro' e 'espectadores', theatron e theatai, primeiramente encontrados nos autores do séc. V a.C., impliquem que seria expectável que as performances se desenrolassem mais para ser vistas do que ouvidas, a verdade, na opiniāo de Stanford (1983: 76), é que essa seria a realidade

${ }^{43}$ Cf. Filócoro, FGrH 328 F 64 b.

${ }^{44}$ Cf. Teofrasto, Carateres, 5.7.

${ }^{45}$ Havia ainda lugares reservados para o sacerdote de Diónisos - no centro da primeira fila - para os membros da Assembleia, para os epheboi (escólio a Aristófanes, Aves, 794) e ainda filas destinadas a cada uma das 10 tribos. Sobre a localização dos lugares de honra, vide cap. 2, 43-44.

46 Segundo Webster (1970: 16), do local da representação à primeira fila dos espectadores distava cerca de 18 metros no século V a.C. e acima dos 21 metros no século IV a.C. As últimas filas do teatro de Diónisos situavam-se a cerca de 91,5 metros do palco. 
apenas dos primeiros tempos, quando as cerimónias rituais e as danças constituíam o cerne do culto báquico, mas que, quando os poetas substituíram os sacerdotes e os dançarinos, então as palavras passaram a ocupar um lugar de eleição.

Era pois por intermédio das palavras que os espectadores, principalmente os mais distanciados, se apercebiam de quem entrava em cena (através do anúncio do nome pelo próprio ou por outro interveniente já em cena), de quem falava (porque existiam paralelismos convencionais no esquema do discurso que permitiam ao espectador detetar a alternância de emissor) e, muitas vezes, de como era o cenário que tinha de ser idealizado (já que, na impraticabilidade de se colocar em cena todas as referências materiais e/ ou todos os adereços, as palavras cumpriam o papel de estimular a imaginação da audiência e conduzi-la para o ambiente que a peça requisitava). Eram também as palavras o motor que impulsionava as emoçóes e os sentimentos que, através do teatro, se pretendia que os espectadores atingissem - a compaixáo (eleos) e o temor (phobos) ${ }^{47}$ - de forma a que a catarse (katharsis) das paixóes (pathemata) fosse plena.

${ }^{47}$ Vide Aristóteles, Poética, 6.1449b27-8. 


\section{Conclusāo}

Por tudo quanto foi dito é possível constatar que o teatro grego resultava da fusão de vários componentes e que contemplava em si várias dimensóes. Daí que, numa primeira análise, três aspetos ressaltem: a sublime combinação de várias artes no espetáculo teatral (a representação, a dança, a música, a poesia), as várias dimensôes de que o teatro estava imbuído (religiosa, política, social, cultural) e a evolução que se foi desenrolando ao longo dos tempos nas performances teatrais.

Assim, e relativamente ao primeiro aspeto, procurámos demonstrar que uma das maiores particularidades do espetáculo grego consistia na forma magistral como estas várias artes conviveram durante séculos, sendo que, por isso, era possível identificar nas intervençóes do coro e dos atores três modos de elocução que se relacionavam numa escala maior ou menor com a música, a dança e a poesia. Desta forma, os trechos sem acompanhamento musical (kataloge) estavam mais diretamente relacionados com a arte de representação; os trechos com acompanhamento musical ou recitativos (parakataloge) pressupunham a presença da música e de um certo movimento rítmico e compassado; as partes cantadas (melos), existentes sobretudo em momentos reflexivos e de grande emoção, conjugavam harmoniosamente a música, a dança e a poesia. De qualquer forma, ainda que diversos, estes modos de elocução tinham, no entanto, uma característica comum e que sem dúvida se constituía como um dos requisitos fundamentais do teatro grego - a palavra.

A palavra tinha, pois, a função mágica de colmatar todas as lacunas que um teatro ao ar livre e com as dimensóes que possuía não conseguia contornar. Foi ela que, desde os primórdios, desenhou os cenários que só mais tarde (e ainda assim de forma incompleta) a skene permitiu que se exibissem; era ela que ajudava os espectadores mais distantes a reconhecerem as personagens que entravam em cena, era ela o veículo de que o ator se servia para demonstrar as emoçóes vividas. A par da palavra, a máscara e o vestuário possibilitavam também a identificação pelos espectadores do sexo, da idade e do estatuto 
das personagens representadas, sendo que, por isso, também eles se afirmaram como elementos fundamentais no contexto teatral da Antiguidade Clássica. O reforço do hábil uso da palavra e da argumentação acabariam também por contribuir, juntamente com outros elementos, para a valorização progressiva do ator individual em detrimento da atuação coletiva do coro.

Este destaque que, a partir de determinada altura, os atores passaram a deter acabou por se refletir em toda a performance dramática, não só porque o edifício teatral sofreu alteraçôes com a introdução do proscénio - um palco de madeira, ligeiramente elevado, que ficava encostado à skene e interligado com a orquestra através de degraus -, como também as máscaras e o calçado evoluíram de acordo com este novo estatuto dos atores. Assim, para atenuar a maior distância entre audiência e atores, agora confinados ao proscénio, e para reforçar o papel de preponderância destes últimos elementos, foi necessário conferir-lhes uma altura e majestade extras e, por isso, as máscaras passaram a ostentar o onkos - uma elevação acima da testa - e os atores teráo começado também progressivamente a adotar um tipo de calçado com uma sola bastante elevada. Estes aspetos, destinados a acentuar a centralidade dos atores, são igualmente sintoma de uma tendência para o exagero verificada sobretudo na Época Helenística, quer na forma de representar, quer na preferência dada a complexos malabarismos vocais, quer ainda nos gestos efetuados que passaram a ser mais largos e pronunciados.

Por outro lado, este destaque conferido aos atores em detrimento do coro teve também implicaçóes de caráter religioso, porquanto eram estes representantes da coletividade, com o seu ritual de solenidade e a sua função profética, que metaforicamente emprestavam ao espetáculo a sua dimensão religiosa, sendo que, por isso, com o relegar do coro para segundo plano e com a delimitaçáo física que se operou no edifício teatral, separando-se por intermédio de um muro o local destinado às performances e o reservado ao culto de Diónisos, inevitavelmente esta vertente foi-se esbatendo. Consequentemente, também em termos sociais houve repercussóes, dado que era nos elementos do coro, que participavam de forma voluntária e com a consciência do cumprimento de um dever cívico, que se faziam representar as dez tribos atenienses. Assim, a pouco e pouco o teatro foi-se despindo das facetas que o caracterizavam 
nos primeiros tempos e cada vez mais foi-se autonomizando enquanto acontecimento cultural. Para esta situação terá ainda contribuído o público, para quem o ponto de interesse passou a ser o ator e cujo gosto passou a estar inclinado para performances vincadamente mais espetaculares. Este público, também ele uma marca da democracia ateniense - na medida em que era composto por todo o tipo de cidadáos, homens, mulheres, crianças, bem como por escravos e estrangeiros, com maior ou menor grau de cultura e com profissóes variadas -, constitui por isso mesmo outra das particularidades que sobressaem do teatro grego e que nunca mais se fez sentir, pelo menos na mesma escala e com a mesma intensidade: é que este público comungava de um interesse comum - prestar verdadeira honra a Diónisos -, participando de forma incisiva e fervorosa nos festivais que lhe eram dedicados, e demonstrando, consequentemente, uma predisposição consciente e apaixonada relativamente ao mundo do teatro. Por este conjunto de fatores, o teatro não podia deixar de acompanhar, em termos performativos, a evoluçáo de gostos desse mesmo público, que constituía, afinal, a razão última de ser de um espetáculo. 
(Página deixada propositadamente em branco) 


\section{Bibliografia}

BaIn, David, Ators and Audience: a Study of Asides and Related Conventions in Greek Drama (Oxford \& New York, Oxford University Press, 1977).

Belessort, André, Athénes et son Théâtre: Cours Professé à la Société des Conférences (Paris, Lib. Académique Perrin, 1954).

Bieber, Margarete, The History of the Greek and Roman Theatre (Princeton, Princeton University Press, 1961).

Brooke, Iris, Costume in Greek Classic Drama (Princeton, Methuen, 1962).

Calame, Claude, Les Choeurs de Jeunes Filles en Grèce Archä̈que (Roma, Edizioni dell'Ateneo \& Bizzarri, 1977).

"The Tragic Choral Group: Dramatic Roles and Social Functions" in Rebecca Bushnell (ed.) A Companion to Tragedy (Malden, Blackwell Publishing, 2005), 215-233.

Camp, John, M., The Archaeology of Athens (New Haven \& London, Yale University Press, 2001).

Capone, Gone, L'Arte Scenica degli Attori Tragici Greci (Padova, Pubblicazione della Facoltà di Lettere e Filosofia / Università di Padova, 1935).

Carrière, Jean, "Le Choeur secondaire dans le drame grec: Sur une resource méconnue de la scène antique" in Etudes et Commentaires, 58, (Paris, Librairie C. Klincksieck, 1977).

Centanni, Monica, Metro, Ritmo e Parola nella Tragedia Greca: le Scene in Tetrametri Trocaici (Lecce, Argo, 1995).

Chanzedon, Christophe, "La Base de Satyros à Delphes: le Théâtre Classique et son Public à l'Époque Hellénistique" CGITA 11 (1998) 33-58.

Comotтi, Giovanni, "La Musica nella Tragedia Greca" in Scena e Spettaccolo nell'Antichità - Atti del Convegno Internazionale di Studio (Trento, Leo S. Olschki, 1989) 43-61. 
Connor, W. R., 'City Dionysia and Athenian democracy', C\&M 40 (1989) 7-32.

Csapo, Eric \& Slater, William, J., The Context of Ancient Drama (Ann Arbor, University of Michigan, 1994).

Dale A. M., "The Chorus in the Action of Greek Tragedy", in H. D. F. Kitto (ed.) Classical Drama and its Influence (London, Methuen, 1965) 556-557.

Metrical Analyses of Tragic Choruses, Bulletin Supplement $\mathrm{n}^{\mathrm{o}} 21.1$ (London, University of London, Institute of Classical Studies, 1971).

D'Arnoti, Peter, Public and Performance in the Greek Theatre (London \& New York, Routledge, 1989).

Dearden, C. W., 'The Poet and the Mask Again', Phoenix 29 (Canada, University of Toronto Press, 1975) 75-82.

- The Stage of Aristophanes (London, Athlone Press, 1976).

Dover, K. J., "Portrait-Masks in Aristophanes" in R. E. H. Westerdorp Boerma (ed.): Studia Aristophanea Viri Aristophanei / W.J. W. Koster in honorem (Amstelodami, Hakkert, 1967) 16-28.

Duncan, Anne, Performance and Identity in the Classical World, (Cambridge, Cambridge University Press, 2006).

Frazier, Françoise, "Public et Spetacle dans la Poétique d'Aristote”, CGITA 11 (1998) 123-144.

Ferreira, José Ribeiro, A Democracia na Grécia Antiga (Coimbra, Livraria Minerva, 1990).

Gigante, Marcello, "La Parole et la Voce" in Scena e spettaccolo nell'antichità - Atti del Convegno Internazionale di Studio (Trento, Leo S. Olschki, 1989) 11-19.

Ghiron-Bistagne, Paulette, Recherches sur les Acteurs dans la Grèce antique (Paris, Les Belles Lettres, 1976).

Green, J. R., Theatre in Ancient Greek Society (London \& New York, Routledge, 1994).

Haigh, A. E., The Attic Theatre: a Description of the Stage and Theatre of Athenians and of the Dramatic Performances of Athens (Oxford, Clarendon Press, 1907). 
Hall, Edith, Inventing the Barbarian: Greek Self-Definition through Tragedy (Oxford, Clarendon Press, 1989).

Halliwell, Stephen, “The function and Aesthetics of the Greek Tragic Mask', in Niall W. Slater and Bernhard Zimmermann (eds.) Intertextualität in der griechisch-römischen Komödie (Stuttgart, M und P., Verl. fur Wiss. und Forschung, 1993) 195-211.

Harsh, Philip Whaley, A Handbook of Classical Drama (California, Standford University Press, 1944).

Herington John, Poetry into Drama: Early Tragedy and the Greek Poetic Tradition (Berkeley, University of California Press, 1985).

Jesus, Carlos, "Dancing with Plutarch. Dance and dance theory in Plutarch's Table Talk", in J. R. Ferreira (et alii, edd.), Symposion and Philanthropia in Plutarch (Coimbra, 2009) 403-414.

Jones, John, On Aristotle and Greek Tragedy (Londres, Chatto \& Windus, 1967).

Kassel, R., Austin, C. (edd.), Poetae Comici Graeci. Vol. II (Walter de Gryter, Berlim, 1991).

Macdowell, Douglas M., Aristophanes and Athens: an Introduction to the Plays (Oxford, Oxford University Press, 1995).

Matino, G., “Terminologia della Scena nella Tragédia Attica”, in E. García Novo, I. Rodríguez Alfageme (eds.) Dramaturgía y Puesta en Escena en el Teatro Griego (Madrid, Ediciones Clásicas, 1998) 151-166.

Marshall, C. W., "Some fifth-century Masking Conventions" $G \& R 46$ (1999) 188-202.

"The Costume of Hecuba's attendants" AClass 44 (2001) 127-136.

McCloud, Scott, Understanding Comics: the Invisible Art (New York, HarperPerennial, 1994).

Murnaghan, Sheila, "Women in Greek Tragedy" in Rebecca Bushnell (ed.) A Companion to tragedy (Malden, Blackwell Publishing, 2005) 234-250. 
Nauck, A., Tragicorum Graecorum Fragmenta (Heildesheim, 1964). [frs. Nauck²]

Pickard-Cambridge, A. W., The Theatre of Dionysus in Athens (Oxford, Oxford University Press, 1946).

The Dramatic Festival of Athens (London, Oxford University Press, 1953).

ReEs, Kelley "The Meaning of Parachoregema” CPh 2 (1910) 387-400.

ReHm, Rush, Greek tragic theater (London; New York, Routledge, 1992).

Rispoli, M. Gioia, “La Voce dell' Attore: Teorie e Tecniche” in E. Garcia Novo, I. Rodríguez Alfageme (eds.) Dramaturgía y Puesta en Escena en el Teatro Griego (Madrid, Ediciones Clássicas, 1998) 53-65.

Rocha Pereira, Maria Helena, Estudos de História da Cultura Clássica: Cultura Grega, vol.1 (Lisboa, Fundação Calouste Gulbenkian, 2006).

Schlesinger, Alfred Cary, Boundaries of Dionysus: Athenian Foundations for the Theory of Tragedy in Martin Classical Lectures, vol. 27 (Cambridge; Massachusetts, Harvard University Press, 1963).

Seale, David, Vision and Stagecraft in Sophocles (London, Croom Helm, 1982).

Sommerstein, Alan H., Aeschylean Tragedy, (Bari, Alan H. Publisher, 1996).

"The Theatre Audience, the Demos, and the Suppliants of Aeschylus", in Cristopher Pelling (ed.) Greek Tragedy and the Historian (Oxford, Clarendon Press, 1997) 63-80.

Sifakis, G. M., "Studies in the History of Hellenist Drama", in University of London Classical Studies, 4 (London, the Athlone Press, 1967).

Stanford, William B., Greek Tragedy and the Emotions (London \& Boston, Routledge \& Kegan Paul, 1983). 
Taplin, Oliver, The Stagecraft of Aeschylus (Oxford, Clarendon Press, 1977).

Greek Tragedy in Action (Berkeley, University of California Press, 1978).

Comic Angels and Other Approaches to Greek Drama through Vase-Painting (Oxford, Oxford University Press, 1993).

"Comedy and the Tragic" in M. S. Silk (ed.), Tragedy and the Tragic: Greek Theatre and Beyond (Oxford, Clarendon Press, 1996).

- Pots \& Plays: Interactions between Tragedy and Greek Vase-painting of the Fourth Century B.C. (Los Angeles, J. Paul Getty Museum, 2007).

Thomson, George, Aeschylus and Athens (London, Lawrence \& Whishart, 1941).

TAYlor, David, Acting and the Stage (London, George Allen \& Unwin, 1978).

Travlos, John, Pictorial Dictionary of Ancient Athens (New York, Praeger Publishers, 1971).

Walton, J. Michael, Greek Theatre Practice (London, Methuen, 1991).

Webster, T.B.L., "The Poet and the Mask" in M. J. Anderson (ed.) Classical Drama and its Influence (London, Methuen, 1965) 5-13.

- Monuments Illustrating Tragedy and Satyr Play, Bulletin Supplement, no 20, (London, Institute of Classical Studies, 1967).

- Greek Theatre Production, (London, Methuen, 1970).

Wiles, David, The Masks of Menander: Signs and Meaning in Greek and Roman Performance (Cambridge, Cambridge University Press, 1991).

- Tragedy in Athens: Performance Space and Theatrical Meaning (Cambridge; New York, Cambridge University Press, 1997). 
Greek Theatre Performance: an Introduction (Cambridge, Cambridge University Press, 2000).

A Short History of Western Performance Space (Cambridge, Cambridge University Press, 2003).

Wilson, Peter, "Leading the Tragic Khoros: Tragic Prestige in the Democratic City", in Cristopher Pelling (ed.) Greek Tragedy and the Historian (Oxford, Clarendon Press, 1997) 81-108.

Zeituin, Froma I., "Playing the Other: Theater, Theatricality, and the Feminine in Greek Drama" in J. Winkler and F. Zeitlin (eds.) Nothing to Do with Dionysos?: Athenian Drama in its Social Context (New Jersey, Princeton University Press, 1990) 63-96.

Zimmermann, Bernhard, Greek Tragedy: an Introduction (Translated by Thomas Marier) (Baltimore \& London, The Johns Hopkins University Press, 1991).

Os títulos apresentados na Bibliografia dizem respeito apenas a estudos. Todas as referências a traduçóes e comentários são indicadas nas páginas do corpus do trabalho. 


\section{GLOSSÁRIO}

Acrópole - Parte mais elevada da cidade de Atenas que albergava algumas das mais famosas edificaçóes do mundo grego, tais como o Pártenon e o Erectéion. À letra, o termo significa 'cidade alta'.

Agon - Termo que designa conflito e, por inerência, debate.

Agones chytrinoi - Concursos que decorriam no terceiro dia do festival das Antestérias.

Agonothetes - Oficial eleito anualmente, no período helenístico, para organizar o festival das Grandes Dionísias, e a quem era atribuído um fundo monetário.

Ágora - Local que primordialmente servia os interesses públicos, religiosos e culturais, passando depois também a desempenhar funçóes comerciais.

En agrois - À letra, 'nos campos', ou seja, num local fora dos muros da cidade.

Alazon - Personagem típica da comédia que representava os charlatães e fanfarrôes.

Amoibaios - Canto amebeu. Diálogos cantados ou cânticos alternados.

Aner - Personagem de homem maduro, caraterizado com face escura e com barba e cabelos pretos.

Apate - Engano.

Apokinos - Dança lasciva.

Architekton, Theatrones ou Theatropoles - Responsável pelo edifício teatral.

Arconte Basileus - Magistrado responsável pela maior parte dos deveres religiosos, cujas funçóes recuariam possivelmente a uma fase monárquica do primitivo governo de Atenas. 
Arconte-epónimo (eponymos) - Principal oficial político do estado ateniense.

Aristerostata - Ala que, na formação do coro por filas (kata zyga), ficava mais próxima da audiência.

Askoliasmos - Concurso que consistia na tentativa de saltar por cima ou permanecer sobre um odre cheio de vinho e untado.

Basilinna - Mulher do arconte-rei ou Basileus.

Charoneioi klimakes - À letra, 'escadas de Caronte'; passagem subterrânea, introduzida durante a Época Helenística, que culminava numa escadaria que dava acesso à orquestra e permitia apariçóes fantasmagóricas.

Cheiridotos chiton - Peça usada pelos atores sobre a túnica.

Cheironomia - Arte do movimento das mãos.

Chiton - Túnica de origem dórica ou iónica, usada em atividades militares, que ficava presa aos ombros por intermédio de alfinetes.

Chlamys - Túnica usada sobretudo por soldados e mensageiros, relativamente curta e que ora surgia amarrada à volta do corpo por baixo de um dos braços e da cintura ora era fixada por um alfinete no ombro, caindo depois a direito.

Choes - Segundo dia do festival das Antestérias, conhecido como o festival dos vasos de libaçóes.

Chorodidaskalos (pl. chorodidaskaloi) - Diretor de coros que assumia a função de instruir o coro, organizar a representação, tratar da cenografia, distribuir as partes e dirigir a interpretação dramática.

Chytroi - Terceiro dia do festival das Antestérias designado de Festa das 'Marmitas'.

Corego - Cidadão rico, designado pelo arconte-epónimo, que assumia a responsabilidade dos concursos dramáticos e, por inerência, dos gastos decorrentes dos ensaios dos coros, do seu vestuário e alimentação. 
Deixis - Uma das modalidades da dança teatral, correspondente à exibição ou demonstração conseguida através de gestos.

Demos - Pequenas circunscriçôes territoriais, semelhantes às modernas freguesias, que se repartiam por zonas urbanas, montanhosas e rurais.

Deuteragonistes - Deuteragonista.

Didaskalos - Encenador ou pessoa que dirige os ensaios.

Dionysokolakes - Aduladores de Diónisos. Termo que na época helenística começou a ser usado para designar os atores.

Eisagoge de Diónisos - Ritual que consistia numa reconstituição do advento do deus desde Eleutherai, na Beócia, até à Ática.

Eisodos (pl. eisodoi) - Outra das designações dos acessos laterais para a orquestra. Cf. exodos.

Ekkyklema (pl. ekkyklemata) - Máquina rolante ou plataforma movível, feita de madeira, que tinha como principal função dar a conhecer ao público o resultado de cenas que decorreriam no interior da skene, nomeadamente mortes de personagens.

Ekskeua prosopa - Máscaras especiais que fugiam aos tipos convencionais e que eram usadas para representar, sobretudo, seres excecionais.

Eleos - Compaixão.

Embades - Calçado do dia a dia, usado na comédia.

Embolima - Cânticos executados pelo coro, nos interlúdios das peças, que não apresentavam qualquer relação com os acontecimentos representados no espaço cénico.

Emmeleia - Dança contida, típica da tragédia.

Ephebos - Efebo; jovem do sexo masculino em idade militar. Enquanto tipo convencional do teatro era representado como um jovem, de face escura e cabelo preto.

Epimeletes (pl. epimeletai) - Intendente.

Epinikia - Epinícios ou odes vitoriosas que invocavam o mundo 
das competiçôes atléticas e do ideal aristocrata do belo e nobre vencedor.

Epiparodos - Momento que correspondia à reentrada do coro em cena, quando, depois de abandonar a orquestra, protagonizava um segundo párodo.

Episkenion - Segundo piso da skene que funcionava como cenário.

Episódios - Partes da tragédia e que correspondem ao desempenho dos atores entre as músicas corais.

Epode - Parte que, numa ode coral, correspondia à última intervenção do coro e que significava literalmente 'depois do cântico'. Em português, usa-se a designação de epodo.

Eschara - Altar de sacrifícios.

Estásimos - Partes cantadas da tragédia, cujo nome estava relacionado com o facto de o coro estar já na orquestra, quando executava esses cantos, na sua posição habitual - stasis.

Ethos - Traços característicos. Hábitos ou costumes.

Euphonia - Eufonia ou 'boa voz'.

Exodos - 'Saída', termo usado para designar a parte final da tragédia - êxodo - e que coincidia geralmente com a altura em que o coro saía de cena, abandonando a orquestra por um dos seus acessos laterais. Cf. eisodos.

Exomis - Veste branca e inteiriça sem qualquer tipo de costura do lado esquerdo.

Gerairai - 'Veneráveis' sacerdotisas de Diónisos.

Geron - Personagem de homem velho, caraterizado com face escura e com barba e cabelos brancos. Geralmente, calvo.

Graus - Personagem de mulher velha, caraterizada com face pálida e cabelo branco.

Gyne - Personagem de mulher madura, de face pálida e cabelo preto, com um penteado apropriado a uma mulher adulta.

Himation - Manto usado quer pelos homens quer pelas mulheres que ficava acima do joelho. 
Hoplitas - Soldado de infantaria pesada da antiga Grécia. O termo deriva do facto de estes soldados transportarem para as batalhas um escudo grande - hoplon.

Hybris - Insolência ou ultraje.

Hypoboleus - Subordinado que teria como tarefa recitar o texto teatral para que os atores o decorassem.

Hypokrites - Palavra usada para designar ator em geral (cómico ou trágico, protagonista ou não), mas que significa à letra 'o que responde'. Em português, a palavra deu origem ao termo hipócrita.

Hypotheseis - Textos que apresentavam sinopses sobre alguns autores da Antiguidade e respetivas obras.

Ikria - Termo que à letra significa 'lugares sentados'. Primordialmente o vocábulo referir-se-ia aos assentos de madeira existentes na Ágora, de onde os espectadores assistiam aos concursos dionisíacos, antes de o teatro de Diónisos ter sido construído.

Kalathiskos - Gesto que consistia em colocar as mãos em forma côncava acima da cabeça.

Kandys - Túnica, curta ou comprida, que podia surgir com ou sem mangas.

Kanephoros - 'Canéfora'; jovem pertencente à aristocracia que, durante a procissáo (pompe) das Dionísias, transportava um cesto de oiro, contendo os primeiros frutos para o sacrifício.

Kata stoichous - Formação do coro que pressupunha a distribuição dos quinze elementos por três filas, com cinco elementos cada, ficando a frente com cinco elementos.

Kata zyga - Formação do coro que pressupunha a distribuição dos quinze elementos por três filas, com cinco elementos cada, ficando a frente com três elementos.

Katablemata - Telas fixadas na skene e pintadas de forma muito simples que funcionavam como cenário.

Kataloge - Trechos sem acompanhamento musical. 
Katharsis - Catarse ou purificação das paixôes, operada pelo teatro, e que recaía sobre o espectador.

Knismos - Dança exótica, originária da Pérsia.

Kommos - Canto de luto, cujo significado literal é 'bater com as mãos no peito'; geralmente relacionado com manifestaçóes de dor por parte das mulheres.

Komodos - Palavra que designa ator cómico, mas que foi usada também para mencionar comédia, coreuta cómico e comediógrafo.

Komos - Cortejo onde era exibido e ostentado um falo com o objetivo de promover a fertilidade. Era também o cortejo vitorioso que distinguia o corego e o poeta que alcançavam o primeiro lugar nos festivais. Nas comédias, era o festejo hilariante com que geralmente as mesmas terminavam.

Kopha prosopa - Figurantes ou 'personagens mudas' do teatro.

Kordax - Dança típica da comédia.

Kore - Personagem de mulher jovem, de face pálida e cabelo preto, com um penteado infantil.

Kothornos - Calçado usado pelos atores trágicos; por extensão, este termo passou à linguagem corrente para designar assuntos de natureza trágica ou que exigem uma particular seriedade no tratamento. No século $\mathrm{V}$ a.C., parece provável que os atores usassem um tipo de calçado simples e maleável que chegava a uma determinada altura da perna e cuja biqueira ficava relativamente levantada. A sola fazia parte da mesma peça com que se fabricava a bota e era fina o suficiente de forma a náo impedir os movimentos. No período helenístico, o kothornos passou a apresentar solas extremamente elevadas (entre 10 e 25 centímetros).

Lamprotes - Limpidez na voz.

Laurostata ou deuterostata - Ala que, na formação do coro por filas (kata zyga), ficava no centro da formação.

Logeion - Parte superior do proscénio reservado à fala.

Lyssa - Raiva. 
Máscaras en mone othone - Máscaras brancas.

Mechane - Espécie de grua ou guindaste que transportava os atores para níveis elevados como o theologeion e que era usada também para dar a sensação de que a personagem estaria a voar, pelo que era um mecanismo usado recorrentemente para fazer os deuses entrarem em cena. Daqui provém a expressão latina deus ex machina. Cf. Theos apo mechanes.

Megalophonia - Boa projeção vocal.

Melos - Parte cantada de uma peça, existente sobretudo em momentos reflexivos e de grande emoção.

Mesodos - Passagem independente que, numa ode, podia surgir entre a estrofe e a antístrofe e que significava literalmente 'cântico do meio'.

Metastasis - Parte das tragédias em que o coro operava uma 'deslocação' ou 'mudança', abandonando por momentos a orquestra.

Methe-Embriaguez.

Ode - Canção.

Odeum - Edifício de forma quadrangular que ficava do lado este do teatro de Diónisos, onde decorriam concertos de música e, entre outras atividades, o proagon.

Oistros - Paixão.

Oknos - Preguiça.

Onkos - Elevação da máscara acima da testa, visível sobretudo na época helenística.

Orchestra - Começou por ser a designação dada a um espaço presumivelmente circular existente na Ágora. Mais tarde, o termo passou a referir-se ao local destinado às danças corais. À letra, o vocábulo designa 'local onde se podia ver o coro dançar'. Daqui provém o termo 'orquestra'.

Paianes - Péanes (sing. péan), canto solene geralmente em honra de divindades.

Pandia - Festividade em honra de Zeus que ocorria no dia a seguir aos concursos nas Grandes Dionísias. 
Parábase - Altura em que o coro quebrava a ilusão cénica e se dirigia diretamente à audiência. A parábase está presente na maior parte das comédias.

Parabenai tettara - Gesto que supostamente significava 'cair de quatro'.

Parachoregemata - Elementos acessórios no teatro, como os figurantes.

Parakataloge - Trechos com acompanhamento musical, recitativos.

Paraskenia - Estruturas situadas nas partes laterais da skene e projetadas cinco metros em relação a esta, que garantiam as condiçóes exigidas para a exibição de mais do que um edifício e que se destinavam também à representaçáo dos atores.

Parastatai - Coreutas que ladeavam o corifeu e que, por isso mesmo, se destacavam dos restantes, situando-se logo a seguir àquele em termos de importância.

Paredroi-Assistentes.

Parodoi - Partes laterais do teatro por onde o coro fazia a sua entrada na orquestra. $\mathrm{O}$ vocábulo 'párodo' refere-se também à parte da tragédia que corresponde à primeira intervenção do coro, exatamente por, em geral, coincidir com este movimento de entrada.

Pathemata - Paixóes.

Peplos - Tipo de túnica presa aos ombros através de um colarinho quadrangular, que caía ao longo do corpo e ficava ajustada à cintura através de um cinto largo, forte e ornamentado.

Periaktos (pl. periaktoi) - Painéis de madeira e com a forma de prisma que podiam ser fixados nos flancos da skene e que em cada um dos lados ostentavam um cenário diferente, permitindo assim mudanças rápidas.

Peristiarchoi ou periestiarchoi - Pessoas responsáveis pela purificação do espaço do teatro antes dos festivais, através da derramação do sangue de um leitão.

Phallos (pl. phalloi) - Falos exibidos durante os festivais dedicados a Diónisos. 
Phobos-Temor.

Phonaskia - Liçóes de dicção ministradas por atores, em particular a oradores.

Phora - Uma das modalidades da dança teatral correspondente ao movimento.

Phthonos - Inveja.

Pithoi - 'Tonéis' ou vasilhas que continham o vinho do último outono, usado nas libações.

Pithoigia - Festa da abertura dos tonéis (pithoi) que ocorria no primeiro dia das Antestérias.

Ploutoi - 'Riquezas'; Pluto era o senhor das riquezas.

Pnix - Espaço usado, em Atenas, para as reuniōes da Assembleia, situado numa colina próxima da Acrópole.

Pompe-Cortejo solene que antecedia os concursos teatrais.

Pornoboskoi - Proxenetas.

Proagon - Preleção dada pelos poetas nas Grandes Dionísias sobre as composiçóes que estavam prestes a exibir.

Probole (pl. probolai) - Acusaçôes em tribunal de transgressores da lei ou da santidade dos festivais.

Proedriai - Lugares de honra do teatro destinados a figuras de relevo ou que tivessem conseguido esse privilégio de outra forma, como, por exemplo, através de uma vitória atlética num dos Jogos.

Prólogo - Início da tragédia e/ ou da comédia e que corresponde à parte que precede a entrada do coro.

Proscénio - Palco, feito inicialmente de madeira, ligeiramente elevado, que ficava encostado à skene e interligado com a orquestra através de degraus.

Prosopon - Termo grego usado para designar a máscara usada pelos atores, mas que também significa face.

Protagonistes - Protagonista.

Pyrriche - Dança guerreira. 
Rapsódias - Recitais épicos efetuados por rapsodos - os responsáveis pelo canto, mas não pela urdidura do poema. O termo significa à letra 'canção costurada'.

Rhabdouchoi - Termo que à letra significa 'portadores do bastão' e que designava a polícia do teatro que estava incumbida de moderar as manifestaçóes de violência.

Schema - Uma das modalidades da dança teatral, correspondente à combinaçáo de passos e atitudes.

Sikkinis - Dança típica dos dramas satíricos.

Sincoregia - Partilha da responsabilidade dos concursos por dois coregos em simultâneo.

Skene - Edifício traseiro junto da orquestra que ficava de frente para os espectadores. Principiou por ser em madeira e temporário, tornando-se depois permanente e em pedra. Internamente, funcionava como local de arrumos e camarim. Externamente, servia de estrutura suscetível de representar um determinado cenário. À letra, o termo significa 'tenda' ou 'cabana'.

Skenotheke - Parte da skene reservada aos arrumos e aos camarins.

Skops ou skopeuma - Dança que sugeria coreograficamente a procura de algo.

Stichomythia - Esquema típico do diálogo teatral que consistia na alternância de emissor verso a verso, de dois em dois versos ou de meio em meio verso. À letra, o termo significa 'contar uma história linha a linha'.

Stoa - Em Atenas, corredor de colunas que permitia a separação física entre o local destinado à representação e o local destinado ao culto - santuário.

Syrinx - Tipo específico de flauta (siringe).

Syrma - Túnica inteiriça até ao chão usada pelos atores.

Ta Dionysia - Grandes Dionísias - o mais importante festival de teatro ocorrido em Atenas que se desenrolava todos os anos, durante o mês de Março. 
Templo en Limnais - Um demo ou bairro ateniense, ao sul da Acrópole.

Theates (pl. theatai) - Espectadores ou audiência. O termo significa à letra 'os que contemplam'.

Theatron - Local (numa área curva) onde, primordialmente, a audiência se sentava na encosta da Acrópole para assistir aos sacrifícios e às danças. $\mathrm{O}$ termo teria grande fortuna na linguagem posterior, sendo a palavra por excelência usada para designar o fenómeno dramático, o 'teatro'.

Theatrones - vide Architekton.

Theatropoles - vide Architekton.

Theologeion - Plataforma de madeira que se situava no telhado da skene e que se destinava essencialmente às intervençóes dos deuses.

Theorikon - Pagamento efetuado pelos espectadores para poderem aceder ao teatro e que se acredita ter sido estabelecido em meados do século $\mathrm{V}$ a. C. por Péricles.

Theos apo mechanes - Deus ex machina. Aparecimento de um deus em cena através do recurso à mechane.

Thesmotheteion - Local onde se reuniam os que examinavam, cada ano, as leis.

Thiasos - Grupo ou associação de pessoas que celebravam um sacrifício em honra de um deus, geralmente Diónisos.

Threnodia - Canto de lamento que geralmente ocorria depois da notícia de uma morte violenta ou do confronto com personagens já cadáveres.

Thymele - Altar sacrificial em pedra que ficava no centro da orquestra.

Tragodos - Palavra que designa ator trágico, mas que foi usada também para mencionar tragédia, coreuta trágico e tragediógrafo.

Trigonos - Instrumento de forma triangular, semelhante à harpa.

Tritagonistes - Tritagonista. 
(Página deixada propositadamente em branco) 


\section{ÍNDICE DE AUTORES ANTIGOS}

\section{Álcifron}

Epistológrafo

$$
\text { 3.35.3: n. 2, } 127 .
$$

\section{Aléxis de Túrios}

frag. 41K: n. 37, 44.

\section{Antífanes}

frag. 189K-A: 133.

frag. 191.13-16K: 43.

\section{Antifonte}

Sobre o coreuta

11: 108.

\section{Aristófanes}

Acarnenses

158: n. 39, 72.

241-279: n. 4, 13; n. 5, 14.

407: n. 29, 40.

412 sqq.: n. $25,70$.

501-508: n. 26, 131.

504: n. 19, 17.

592: n. 39, 72.

658: n. 2, 127.

1216: n. 39, 72.

Schol. ad 202: 15.

Schol. ad 242a: n. 45, 25.

Schol. ad 243a: n. 24, 20.

Schol. ad 504: 15.

Aves

30-36: n. 77, 96.

296: n. 24, 39.

296 sqq.: n. $12,105$.

296-306: 60 .

786-789: 26; 133.

793-796: n. 24, 131.

794: n. 45, 135.

1071 sqq.: n. 15, 129.

Cavaleiros

702-4: n. 35, 43. 


\section{Lisistrata}

761: 88.

982 sqq.: n. $39,72$.

1073 sqq.: n. 39, 72.

Mulheres na Assembleia

1154-1159: 28.

Schol. ad 22: n. 22, 130.

Mulheres que celebram as Tesmofórias

62: n. 39, 72.

395: 44.

643 sqq.: n. 39, 72.

953 sqq.: n. $49,119$.

966 sqq.: n. $49,119$.

1098 sqq.: 42.

Nuvens

326: n. 24, 39.

537-539: 130 .

1201 sqq.: n. 15, 129.

Schol. ad 313: n. 33, 85.

$\mathrm{Paz}$

155-179: 42.

734-747: n. 9, 128.

765-766: n. 19, 130.

962-967: 130; n. 36, 133.

1349: n. 39, 72.

Râs

298: 129.

367-368: n. 80, 97.

809-812: 25.

1060 sqq.: 71.

1063 sqq.: n. $25,70$.

1099-1118: n. 42, 24.

1471: 133.

Schol. ad 406a: n. 29, 21.

Vespas

58-59: n. 16, 129.

903: 88.

1071-1073: n. 42, 73.

1104-1105: n. 42, 73.

1485 sqq.: 93.

Schol. ad 582: n. 56, 120.

Schol. ad 1109: n. 37, 44. 


\section{Aristóteles}

Constituição de Atenas

56.3: n. 47, 25.

Ética a Nicómaco

3.1118a: n. 25, 84.

7.1147a23: n. 17, 82 .

10.1175b1: 134.

Poética

1.1447b25: n. 32, 85.

1.1451b25-26: n. 32, 132.

4.1449a16: n. 2, 79.

4.1449a118: 37.

6.1449b27-28: n. 47, 136.

6.1450a8: 85 .

6.1450b16: 85 .

12.1452b19-22: 113.

12.1452b24: n. 40, 115.

15.1454b: 43 .

18.1456a26 sqq.: n. 19, 107.

18.1456a29-30: n. 17, 106.

19.1456b: n. 23, 84 .

26.1461b29 sqq.: 91 .

26.1461b33-4: 91.

26.1462a1-11: 91 .

Politica

1276b1-9: n. 12, 105.

7.1336b: 96.

Problemas

956b11-12: n. 91, 99.

11.901b5-16: n. 28, 84.

19.918a10-13: n. 31, 85.

19.922a1-20: 86.

19.922b10-27: n. 19, 107.

Retórica

3.1: n. 64, 29.

3.1.1403b: 42 .

3.1403b26-33: n. 17, 82.

3.1403b31-35: n. 87, 98.

\section{Ateneu}

Deipnosofistas

1.21d-22a: n. 31, 22. 
1.22a: n. 64, 92.

11.464f: n. 35, 133.

12.539: 100 .

13.587b: n. 21, 38.

14.629: 93.

14.612d-622d: n. 4, 13.

\section{Aulo Gélio}

Noites Áticas

5.7: n. 5, 51 .

\section{Cícero}

Cartas a Ático

$$
\text { 13.19.3: n. 22, } 83 .
$$

Sobre o orador

2.46.193: n. 10, 52.

\section{Demóstenes}

Contra Midias

8-10: n. 68, 30.

10: n. 7, 14; n. 51, 26.

14-18: n. 24, 108.

17: n. 44, 46.

63: 23 .

156: 22.

178-180: n. 8, 127.

179: n. 10, 128.

Sobre a coroa

28: n. 42, 134.

180: n. 10, 15.

262: n. 82, 97.

Sobre a falsa embaixada

246: n. 17, 82.

337: n. 7, 127.

\section{(Pseudo)-Demóstenes}

Contra Neera

73-78: n. 21, 18.

76: 15 .

\section{Diógenes Laércio}

Vidas e opinióes de filósofos eminentes

7.20: n. 25, 84 . 


\section{Eliano}

História Vária

2.13: n. 11,$15 ;$ n. 32,58 ; n. $27,131$.

Ésquilo

Oresteia:

Agamémnon

55-59: n. 27, 109.

75: n. 24,70 .

116: n. 27, 39.

385-402: n. 34, 111.

1071 sqq.: 115.

1072-1342: 111.

1073-1176: 115.

1164-1166: 110.

1306: n. 61, 91.

1348-1371: 117.

1448-1496: 115.

1651: n. 24, 70.

Coéforas

22-31: n. 51, 90.

34 sqq.: 93.

84 sqq.: 115.

185-186: n. 55, 90.

838-869: 117.

931 sqq.: n. 28, 109.

935-971: n. 39, 114.

Euménides

48-56: 69.

235 sqq.: 121.

243: 121 .

309: n. 49, 119.

1028: 69 .

1032-1046: 116.

Suplicantes

100: 104-105.

321: 104.

[Vida de Ésquilo]

Ésquines

p. 4: n. 25, 56; n. 20, 130.

Contra Ctesifonte

34: n. 18, 82. 
41: n. $18,82$.

45: n. $18,82$.

67: n. 42, 24.

154: n. 18, 82.

Contra Timarco

10: n. 48, 25.

\section{Estéfano de Bizâncio}

Sobre Apolodoro

p. 274, vv. 8-10: 15.

\section{Eurípides}

Andrómaca

494-545: n. 9, 80.

598: n. 13, 67.

822-824: n. 54, 90.

Alceste

77-140: 116.

393-415: n. 9, 80; n. 10, 80.

576: n. 38, 86.

861: 121.

962-983: 111 .

Bacantes

105 sqq.: n. 21, 69.

117: n. 34, 85.

604 sqq.: n. 39, 86.

695 sqq.: n. $21,69$.

862 sqq.: 112.

Fenícias

310 sqq.: 93.

Electra

146-150: n. 51, 90.

859-861: 91.

880-889: 115.

Hécuba

486-487: 90.

736-751: n. 33, 111.

1053: n. 12, 67.

1056 sqq.: n. 67, 93.

Helena

421: n. 28, 70.

554: n. 28, 70. 
1079: n. 28, 70.

1204: n. 28, 70.

1224: n. 11, 52.

1482: n. 38, 86.

Héracles

252-274: 117.

987-993: n. 49, 119.

Ifgénia em Áulide

1036-1097: 106.

1480-1481: n. 49, 119.

Ifigénia em Táuride

1125: n. 38, 86.

Íon

498: n. 38, 86.

Orestes:

280: n. 50, 90.

294-295: n. 50, 90.

390-391: n. 28, 70.

458: n. 24, 56.

Medeia

282 sqq.: n. $28,109$.

1056 sqq.: n. 56, 90.

Suplicantes:

97: 68-69.

234-236: n. $17,68$.

1114-1116: n. 9, 80.

[Vida de Euripides]: n. 42, 24.

\section{Filócoro}

FGrH 328 F 64b: n. 43, 135.

História da Ática

3: n. 42, 134.

\section{Filóstrato}

Heróico

12.2: 18.

Vida de Apolónio

4.21: 19.

4.22: 25.

\section{Fócio}

s.v. ikria: 16; n. 4, 34.

s.v. orchestra: n. 13, 16.

s.v. tritos aristerou: n. 55, 119. 


\section{Frínico}

Frs. 8-12 Nauck²: 116 .

\section{Hesíquio}

Epi Lenaio agon: 15.

Limna: n. 12, 15.

s.v. grammai: n. 54, 119.

s.v. kataloge: n. 30, 85.

\section{Homero}

Ilíada

2: n. 38, 72 .

7.407: 82 .

12.228: 82 .

Odisseia

19.535: 82 .

19.555: 82 .

\section{Horácio}

Arte Poética

193-201: 112.

\section{I. $G$.}

2.2319 col. i: n. 16,17 .

2.2319 col. ii: n. 15,16 ; n. 66, 30 .

2.2320: n. 65, 30 .

2.3042: n. 33, 22.

2.3090: 14 .

II2. 1635a A. 33-4: n. 28, 21.

II2. 2318: 82 .

\section{Isócrates}

Sobre a Paz

$$
\text { 82: n. 55, } 27 .
$$

Trapezitico

$$
\text { 33-34: } 27 .
$$

\section{Lísias}

Defesa contra a acusação de suborno 1-2: 22.

\section{Luciano}

Timon

Schol. ad 49: n. 39, 134; n. 42, 134.

\section{Pausânias}

1.20.3: n. 45, 46. 
1.28.6: n. 25, 56; n. 20, 130.

1.29.2: n. 43, 24.

2.27.5: 46 .

\section{Platáo}

Banquete

175e: n. 59, 28; n. 41, 45.

194a-b: n. 90, 99.

194b: 82 .

Crátilo

425d: 43.

Górgias

502d: n. 18, 130.

Laques

182d-183b: 15 .

Leis

816-817: 123.

2.658a-d: n. 30, 132.

2.659a: n. 58, 28.

2.659a-b: n. 1, 127.

3.700c: n. 10, 128.

6.775b: n. 35, 133.

7.817c: 130.

República

3.397a: 88.

\section{Platónio}

Sobre as diferenças entre comédias

13: 58.

\section{Plotino}

3.2.484: 83 .

\section{Pólux}

4.88: 85.

4.103-105: 93.

4.104: n. 53, 27.

4.108: n. 62, 121.

4.108-109: n. 53, 119.

4.110: n. 25, 56; n. 20, 130.

4.114: 84 .

4.116-117: 71.

4.119-120: 73.

4.124: n. 25, 39. 
4.126 sqq.: 38 .

4.128: 40; 42.

4.130 sq.: 38.

4.131: 38 .

4.132: 43 .

4.132 sqq.: 54 .

4.142: 59 .

9.121: n. 6,14 .

\section{Plutarco}

Moralia

No Banquete

656c: n. 35, 133.

674b: n. 46, 88 .

737b: n. 69, 94 .

9.747a-748e: 92.

Preceitos sobre a forma de conduzir o governo

813e: n. 73, 95.

Sobre a ânsia de riquezas

527d: n. 4, 13.

Sobre a forma correta de escutar

46b: n. 72, 95; n. 22, 108.

Sobre a glória dos Atenienses

349a: 94.

Sobre o E de Delfos

394c: n. 33, 85.

Sobre se os velhos devem tomar parte na condução do governo

785b: n. 84, 98.

\section{Vitae}

Agesilau

21: n. 92, 99.

Cimon

8.7-9: n. 56, 27.

8.8: n. 54, 27.

Péricles

9: n. 38, 134.

\section{(Pseudo)-Plutarco}

Vida dos Dez Oradores

841: 19; n. 88, 99.

842a: n. 8, 14.

848b: n. 25,84 .

852c: n. 40,44 . 


\section{SEG}

15.104.25f: 14.

\section{SIG3}

424A: n. 9, 104; n. 21, 108.

\section{Sófocles}

Ájax

305 sqq.: n. 26, 84.

866: 121

1168 sqq.: 80.

Antígona

441: n. 52, 90.

Édipo em Colono

3-6: n. 27, 70.

14 sqq.: n. 71, 94.

1096-1555: 80.

1104-1105: n. 60, 91.

1130-1131: n. 60, 91.

1414: n. 53, 90.

Filoctetes

161 sqq.: 114.

Rei Édipo

1186-1223: 115.

1524-1531: n. 26, 70.

Traquinias

923-926: n. 13, 67.

947-970: 115.

1181 sqq.: n. 59, 91.

[Vida de Sófocles]

p. 4: n. 20, 83; n. 8, 104.

\section{Suda}

s.v. Aischylos: n. 2, 51.

s.v. Chionides: n. 61, 29.

s.v. Pratinas: n. 7, 34.

s.v. Sophokles: n. 8, 104.

\section{Teofrasto}

Caracteres

5.7: n. 44, 135.

9.5: n. $19,130$. 


\section{Ulpiano}

Sobre Demóstenes, Olintíaca 1.1: n. 41, 134.

\section{Vitrúvio}

5.6.8: 38; n. 25, 39.

5.6.9: 38 .

5.9.1: n. 39, 44.

Xenofonte

Banquete

2.15-17: 92-93.

3.11: n. 29, 131-132.

\section{Zenóbio}

3.64: n. 57, 28. 


\section{ÍNDICE DE IMAGENS}

Ânfora ática de figuras negras, de cerca de 500 a.C. (reprod. Pickard-Cambridge 1953: fig. 162): n. 3, 65.

Ânfora ática de figuras vermelhas do séc. VI a.C., conservada no British Museum (reprod. Pickard-Cambridge 1953: fig. 197): n. 50, 75.

Estatueta de Rieti, um marfim conservado no Museu du Petit Palais (reprod. Csapo \& Slater 1994: Pl. 10D): 74.

Estatueta em terracota, representativa de Héracles, que se encontra em Nova Iorque, no Metropolitan Museum of Fine Art (Reprod. Pickard-Cambridge 1953: fig. 84): n. 40,72 .

Fragmento de um krater do estilo Gnatia de Tarento, conservado no Museu Wagner de Würzburg [reprod. Pickard-Cambridge 1953: fig. 34]: n. 2, 65; 66; n. 8, 66.

Kalyx krater do estilo Gnatia, de Ruvo, conservado em Leninegrado (reprod. Pickard-Cambridge 1953: fig. 177): 90.

Kalyx-krater ático de figuras vermelhas da coleção do J. Paul Getty Museum (reprod. Csapo \& Slater 1994: Pl. 5): 60.

Krater de Andrómeda, um krater ático de figuras vermelhas conservado em Cápua (reprod. Pickard-Cambridge 1953: fig. 164): n. 2, 65; n. 15, 68.

Krater de colunas ático de figuras vermelhas, que se encontra no museu de arte antiga de Basileia (reprod. Csapo \& Slater 1994: Pl. 1A): n. 37, 60; n. 23, 70; n. 63, 122.

Krater de sino de figuras vermelhas de Armento, dos inícios do séc. IV, conservado no Museu do Louvre (reprod. Pickard-Cambridge 1953: fig. 175): 69.

Oinochoe ática de figuras vermelhas encontrada na Ágora de Atenas, de cerca de 470 a.C. (reprod. Pickard-Cambridge 1953: 178-179): n. 3, 51; n. 49, 75.

Pelike ática de figuras vermelhas, conservada no Museum of Fine Arts de Boston (reprod. Pickard-Cambridge 1953: fig. 39): 60. 
Psykter ático pelo pintor Dúris de c. 490-480 a.C., patente no mesmo museu (reprod. Pickard-Cambridge 1953: fig. 199): n. 50, 75.

Reconstituição do teatro helenístico de E.R. Malyon, apud Csapo \& Slater (1994: fig. 15A): , 46.

Vaso Pestense com a mesma configuração, de meados desse século, atribuído ao Pintor de Píton e patente no British $\mathrm{Mu}-$ seum (reprod. Pickard-Cambridge 1953: fig. 176): 69.

Vaso Prónomo, um krater de volutas ático de figuras vermelhas, de cerca de 400 a.C., que se encontra no museu de Nápoles (reprod. Pickard-Cambridge 1953: fig. 28): n. 34, 59; n. 38, 60; n. 2, 65; 71; 73; n. 2, 103; n.11, 105. 


\section{Volumes publicados na Colecçáo "Varia" - Série Monografias}

1. Mariana Montalvão Matias, Paisagens naturais e paisagens da alma no drama senequiano. "Troades" e "Thyestes" (Coimbra, CECH, 2009).

2. João Paulo Barros Almeida, Sentimento e conhecimento na poesia de Camilo Pessanha (Coimbra, CECH, 2009).

3. Cristina Santos Pinheiro, O percurso de Dido, rainha de Cartago, na Literatura Latina (Coimbra, CECH, 2010).

4. Ricardo Nobre, Intrigas Palacianas nos Annales de Tácito. Processos e tentativas de obtenção de poder no principado de Tibério (Coimbra, CECH/CEC, 2010).

5. Weberson Fernandes Grizoste, A dimensão anti-épica de Virgílio e o indianismo de Gonçalves Dias (Coimbra, CECH, 2011).

6. Joana Guimarães, Suicidio Mitico - Uma luz sobre a Antiguidade Clássica (Coimbra, CECH, 2011).

7. Isabel Castiajo, O Teatro Grego em contexto de representaçáo (Coimbra, CECH, 2012). 


\section{OBRA PUBLICADA}

COM A COORDENAÇÃO

CIENTÍFICA

CT Centro de Estudos

CU Classicos e Humanisticos

1

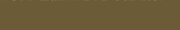

- U 